Portland State University

PDXScholar

\title{
A Study of the Identification and Referral Components of Substance Abuse Intervention Programs in Washington State's Public High Schools
}

Todd C. Herberg

Portland State University

Follow this and additional works at: https://pdxscholar.library.pdx.edu/open_access_etds

Part of the Educational Assessment, Evaluation, and Research Commons, and the Substance Abuse and Addiction Commons

Let us know how access to this document benefits you.

\section{Recommended Citation}

Herberg, Todd C., "A Study of the Identification and Referral Components of Substance Abuse Intervention Programs in Washington State's Public High Schools" (1989). Dissertations and Theses. Paper 1145. https://doi.org/10.15760/etd.1144

This Dissertation is brought to you for free and open access. It has been accepted for inclusion in Dissertations and Theses by an authorized administrator of PDXScholar. Please contact us if we can make this document more accessible: pdxscholar@pdx.edu. 
A STUDY OF THE IDENTIFICATION AND REFERRAL COMPONENTS

OF SUBSTANCE ABUSE INTERVENTION PROGRAMS IN

WASHINGTON STATE'S PUBLIC HIGH SCHOOLS

by

TODD C. HERBERG

A dissertation submitted in partial fulfillment of the requirements for the degree of

\author{
DOCTOR OF EDUCATION \\ in \\ EDUCATIONAI LEADERSHIP: \\ ADMINISTRATION AND SUPERVISION
}

Portland State University

1989 
TO THE OFFICE OF GRADUATE STUDIES:

The members of the Committee approve the dissertation of Todd C. Herberg presented May 3, 1989.

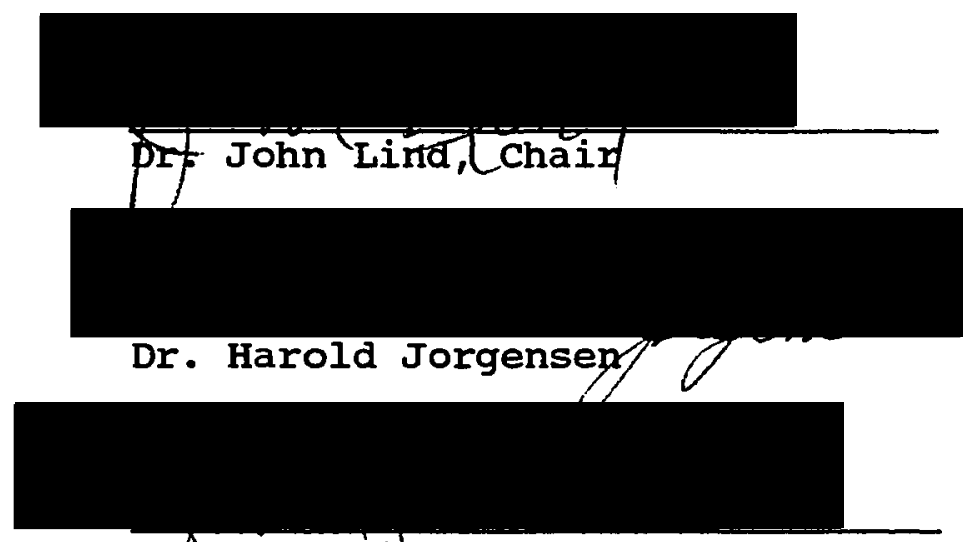

DrA Joan strouse

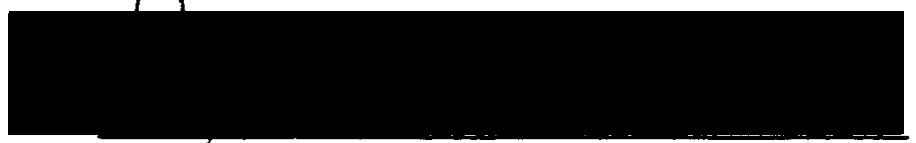

Dr. Maxine Thomas

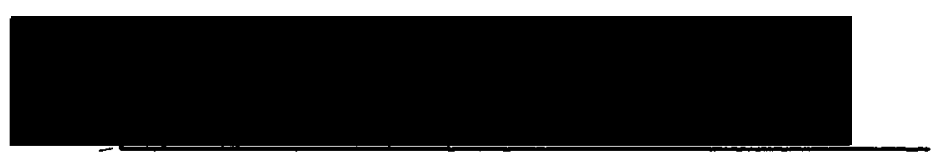

Dr. Leslie McBride

APPROVED:

Robert B. Everhart, Dean, School of Education

Bernard Ross, Vice Provost for Graduate studies 
AN ABSTRACT OF THE DISSERTATION OF TOdd $c$. Herberg for the Doctor of Educational Leadership presented May 3, 1989.

Title: A Study of the Identification and Referral components of Substance Abuse Intervention Programs in Washington State's Public High Schools

APPROVED BY THE MEMBERS OF THE DISSERTATION COMMITTEE:

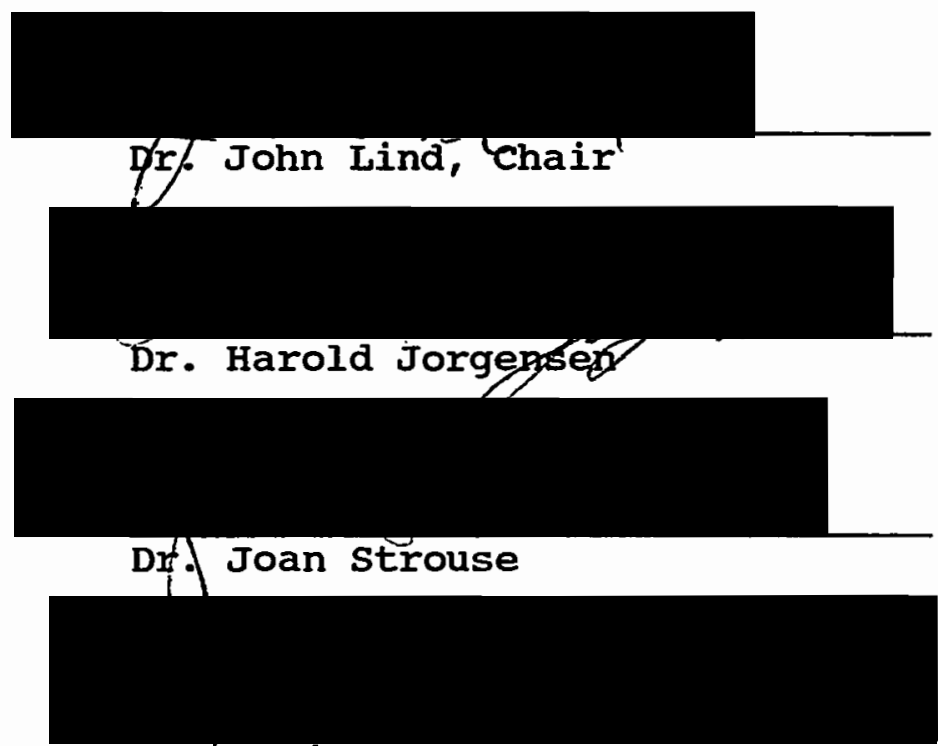

Dr.'Maxine Thomas

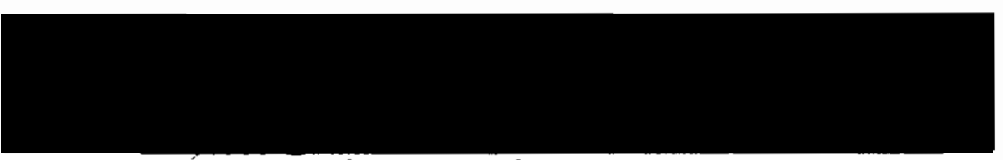

Dr. Leslie McBride

This multiple-case study investigated the characteristics of public high school substance abuse intervention programs that are successful in identifying students harmfully involved with alcohol and/or other drugs and 
referring these students to appropriate services as well as the characteristics of public high school substance abuse intervention programs that are unsuccessful in these areas. For the purposes of this study, schools with the highest rates of identification and referral were determined to be most successful and those schools with the lowest rates of identification and referral were determined to be unsuccessful.

The unit of analysis for this multiple-case study is the public high school substance abuse intervention program of twelve selected Washington state high schools. Sub-units of analysis within the multiple-case study include the various components and attributes of a substance abuse intervention program. Examples of these sub-units include: formal drug education policies; staff training on substance abuse issues and intervention skills; formal curriculum and student instruction; central office administration and building administration support for the program; community support for the program, staff time to administer the overall program, a formalized identification strategy, a formalized referral process, a formal reentry (recovery) program and the availability of formal assessment services for students.

The case study design developed by this researcher included two major activities:

1. A written survey of all Washington state public 
high school intervention programs that identified eight public high schools that were particularly successful and four that were relatively unsuccessful in their ability to identify those students who were harmfully involved with alcohol and/or other drugs and refer these students to appropriate services.

2. A comprehensive examination of the substance abuse intervention programs for twelve selected public high schools through site visitations that included staff interviews, student interviews and the collection of various documents.

A cross analysis of the results from this multiplecase study indicate that successful substance abuse intervention programs share the following characteristics:

- Formal, established identification programs

- The involvement of various staff members in identifying students who are harmfully involved with alcohol and/or other drugs.

- The availability of training in identification strategies for various staff members.

- The availability of specific training in referral strategies for various staff members.

- The availability of formal drug assessments to all students at no cost.

- Established reentry programs that serve the needs of 
students who are returning to school after having received treatment for their chemical dependency or other harmful involvement with alcohol and/or other drugs.

- Administrative support from building principals and central office staff regarding leadership and the allocation of resources. 


\section{ACKNOWLEDGEMENTS}

The completion of this dissertation was made possible through the assistance and support I received from family and colleagues alike.

My sincerest thanks and appreciation go to my committee chairperson, Dr. Jack Lind, for his encouragement and guidance that enabled me to successfully complete my study. To Dr. Lind and the other members of the committee, I extend my deepest gratitude for their wisdom, directness and high expectations. My study was continually strengthened at each phase of the dissertation process by their constructive comments and persistence. Dr. Harold Jorgensen, Dr. Joan Strouse, Dr. Maxine Thomas and Dr. Leslie McBride have nurtured me both professionally and personally. I will always regard them as exceptionally good mentors and wonderful friends.

To my friend, John Hughes, a special expression of thanks for his role in developing me as a substance abuse educator. His professional expertise and accomplishments served as the catalyst for my study, and I hope that my findings can contribute in some way to his continued success in this field.

To my friend and colleague, Dr. Denny Bond, my sincere thanks for his many hours of technical assistance in helping 
me with the survey aspects of this project. In addition to helping me design the survey instrument used in my statewide survey, Dr. Bond was instrumental in assisting me compile the data and sort it for analysis.

My appreciation also goes out to all of my colleagues in Oregon and Washington state who contributed their time and efforts to this study. Their participation was essential to the success of this study, and on behalf of the children who will benefit from their efforts, I thank them.

I also extend my sincere appreciation to Nancy Chapman who served as my technical advisor and typist throughout this project. I will never forget her countless hours of patient assistance, and the commitment she shared with me in completing this study.

Lastly and most dearly, to my wife Joan, and to my children Kristin, Kari and Erik, thank you so very much. Your love, support and understanding were, without a doubt, the greatest inspiration for me in completing this project. It is to my wife, my children and the rest of my family that I lovingly dedicate this dissertation. 
TABLE OF CONTENTS

PAGE

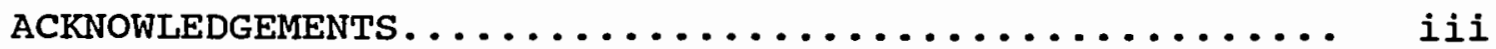

LIST OF TABLES......................... viii

CHAPTER

I INTRODUCTION TO THE STUDY............... 1

The Emergence of Substance Abuse

Intervention Programs.............. 3

Definition of a Substance Abuse

Intervention Program.............. 5

Purpose of This study................ 7

II REVIEW OF RELATED LITERATURE............... 10

Student Substance Abuse............... 11

Problems Related to student Substance

Abuse....................... 19

Substance Abuse Education Programs........ 23

summary........................ 30

III METHODS AND PROCEDURES................ 32

Case studies....................... 34

Research Design.................... 36

study Questions................... 37

Propositions...................... 39

Units of Analysis................... 41

Logic Linking the Data to the Propositions. 41 
Criteria for Interpreting the Findings.....

Validity and Reliability..............

Construct Validity

Internal Validity

External Validity

Reliability

Procedures........................

V DISCUSSION, CONCLUSIONS AND RECOMMENDATIONS.... 75

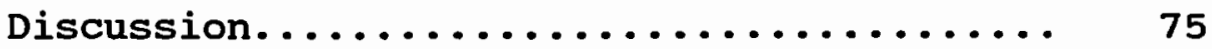

Conclusions..................... 77

Proposition I

Formal Identification Program

Staff Involvement in Identifying Students

Staff Training in Identification

Referral Training

Formal Assessments

Established Re-entry Programs

Administrative Support

Proposition II

Lack of Formal Identification Program

Lack of Staff Involvement in Identifying students

Lack of Staff Training in Identification

Lack of Referral Training

Lack of Formal Assessments

Lack of Established Re-entry Programs

Lack of Administrative Support

Proposition III

Administrative support

Staff Training

Assessment Services

Dedicated Staff Time

Financial Resources 
Recommendations for the Application of Conclusions by Practitioners......... 88

Recommendations and Implications for Further Research................. 92

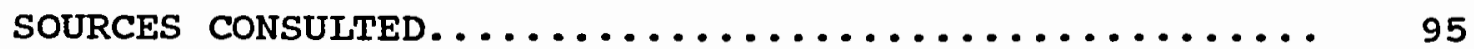
APPENDIX

I DOCUMENTS......................... 105

II $\quad$ CHARTS AND GRAPHS..................... 209

III CASE REPORTS....................... 215 


\section{LIST OF TABLES}

TABLE

PAGE

I High School Senior Drug Use: 1975-87........ 12

II Cross Analysis Grid.................... 74 


\section{CHAPTER I}

\section{INTRODUCTION TO THE STUDY}

Substance abuse education has become a priority issue for Washington state educators. During the 1987-88 school year, the office of the state superintendent of Public Instruction (OSPI) for the state of washington awarded more than 2.5 million dollars in grant monies to local school districts for the purpose of improving substance abuse education efforts. In order to receive these monies, OSPI required local school districts to develop comprehensive substance abuse education programs that included intervention efforts as well as prevention efforts.

Prevention efforts discourage the use of alcohol and other drugs through information curriculums and programs that assist students with social skills and decision making skills to resist peer pressure and make healthy decisions. Intervention efforts, on the other hand, are designed to identify students who are harmfully involved with alcohol and/or other drugs, including students who are chemically dependent. Following identification, intervention efforts should also include a systematic approach to providing these students with adequate treatment and/or counseling services. In addition, intervention efforts typically include support 
activities that assist children of alcoholics as well as chemically dependent students who have received treatment and are returning to the school system.

Although schools throughout washington state have implemented a variety of prevention curriculums during the past two decades, they have only recently begun implementing intervention services for students harmfully involved with alcohol and/or other drugs. For example, washington state awarded approximately 2.5 million dollars to schools in 1987-88 to implement comprehensive substance abuse education programs that include intervention efforts, yet there is very little governance as to the specific components that these intervention efforts should include. It is this researcher's opinion that substance abuse intervention programs must include effective identification and referral components so that students harmfully involved with alcohol and/or other drugs can be identified and then linked to appropriate services. It is also this researcher's opinion that local school districts throughout washington state have implemented a variety of intervention programs that may or may not include components that enable them to successfully identify students who are harmfully involved with alcohol and/or other drugs and refer these students to appropriate services. This researcher believes that this situation exists because substance abuse intervention programs are a relatively new endeavor for public schools, and to date 
there has been a lack of research information available to guide educators in establishing successful identification and referral components for substance abuse intervention programs. This study was conducted to help remedy this situation.

THE EMERGENCE OF SUBSTANCE ABUSE INTERVENTION PROGRAMS

In 1970, U. S. President Richard Nixon stated that substance abuse education had the highest priority as a preventative measure in reducing substance abuse among our nation's young people, and that information and training must be made available to all publicly educated children from kindergarten to grade twelve (Silverstein, Derivan and Hugaboom, 1986).

Over the past two decades numerous state and federal programs were developed to address student substance abuse. Most of these prevention programs were designed to discourage student use of alcohol and/or other drugs through the development of social skills, decision making skills, refusal skills and the presentation of information that illustrates the dangers of substance abuse.

Prevention programs that concentrate on the presentation of information about the dangers of substance abuse have had very little, if any, impact on reducing student substance use (Blum, Blum and Garfield, 1976; Goodstadt, 1978; Hanson, 1980; Kinder, Pape and Walfish, 1980; Swisher, 
1974).

Research studies regarding the effectiveness of prevention programs based on enhancing student decision making skills and social skills are less conclusive (Goodstadt, 1986; Ellickson, Kaham, Polich and Reuter, 1984).

There is, however, considerable research indicating that substance abuse prevention programs based on the development of social skills and decision making skills, as well as information curriculums, are less effective with high school students than those designed for younger students (Johnson, 1983; Johnson, Hansen, Collins and Graham, 1986; Perry, Telch, Killen, Burke and Maccoby, 1983). We know that the average age of students who begin to use alcohol and/or other drugs is between 13 and 14 years (Kandel and Logan, 1984; National Institute for Drug Abuse, 1986). This information suggests that substance abuse prevention programs for many of our high school students may be too late because their alcohol and drug use habits have already been developed. For students who have already established habits related to the use of alcohol and/or other drugs, intervention programs are required. Given the alarmingly high rates of student alcohol and drug use among high school students throughout the United states (National Institute for Drug Abuse, 1988), all of our high schools need effective intervention programs as part of their overall substance abuse program. 
DEFINITION OF A SUBSTANCE ABUSE INTERVENTION PROGRAM

In his book when Chemicals come to school, Gary Anderson (1987) provides the following definition for intervention:

Stated most succinctly, intervention refers to the process of interrupting a harmful pattern of alcohol /drug related behavior. As such, it applies to students who are abusing drugs, to students who are affected by parental alcoholism or to recovering students who may be showing signs of relapse. A typical goal of intervention is to have the individual involved accept his/her need for help. The outcome of the intervention is always a referral to some source of assistance. Thus, having identified a student and having formed an idea of the nature and extent of the student's problem, the program must define the process for referring the student to appropriate care in school or in the community. Intervention and referral can consist of a simple recommendation of a source of information to parents. It can be as complex and time consuming as orchestrating a formal interventive process, involving several key individuals from the school, the family and the community. (p. 97)

Substance abuse specialists agree that there are certain basic services that need to be performed and coordinated to create an intervention program that helps students who are harmfully involved with alcohol and/or other drugs (Anderson, 1987; Griffin and Svendsen, 1986). An effective substance abuse intervention program should provide for:

1. The early identification of those students in need of assistance.

2. An initial assessment of the alcohol and/or drug problem and its severity. 
3. A referral to an appropriate agency or service for assistance.

4. The delivery of appropriate assistance that treats and corrects the problem.

5. Follow up support for the individuals who are correcting their problems.

6. Ongoing administrative support that makes sure that the first five services are being performed.

Substance abuse intervention programs are designed to address the needs of those students who are already harmfully involved with alcohol and/or other drugs. Intervention programs apply to students who themselves are abusing alcohol and/or other drugs, as well as students who are being harmfully affected by the abuse of alcohol and/or other drugs by someone else in their household. Intervention programs include the identification and referral of these students to some special service that will provide them with assistance.

Identification activities within an intervention program include efforts that are designed to teach individuals how to recognize particular student characteristics and behaviors that may indicate harmful involvement with alcohol and/or other drugs. Harmful involvement may be either student use or the harmful effects of an abusing family member. Identification processes may utilize school staff, parents, students, community agencies and other 
authorities, as well as self-referrals by the students themselves (Anderson, 1987; Griffin and Svendsen, 1986).

Referral activities within an intervention program are designed to link students harmfully involved with alcohol and/or other drugs with an appropriate support service. Referral activities typically link students with counseling services, formal assessment services and other diagnostic services that will determine the type and extent of further assistance that is needed.

\section{PURPOSE OF THIS STUDY}

This study of the identification and referral components of substance abuse intervention programs in Washington State's public high schools was intended to address the following purposes:

Purpose I. The first purpose of this study is to identify and describe the characteristics of public high school substance abuse intervention programs that are successful in identifying students harmfully involved with alcohol and/or other drugs and referring these students to appropriate services.

Purpose II. The second purpose of this study is to identify and describe the characteristics of public high school substance abuse intervention programs that are unsuccessful in identifying students harmfully involved with alcohol and/or other drugs and referring these students to 
appropriate services.

Purpose III. The third purpose of this study is to determine the characteristics of a public high school substance abuse intervention program that enable it to be successful in identifying students harmfully involved with alcohol and/or other drugs and referring them to appropriate services by comparing and contrasting the characteristics of successful and unsuccessful public high school substance abuse intervention programs.

Substance abuse intervention programs in our high schools have become an issue of importance among washington state law makers, educators and child service agencies. These individuals and agencies are interested in knowing more about what constitutes successful substance abuse intervention programs in our public secondary schools as well as ideas for how we can improve these programs. They want to know what programs are successful, what makes these programs successful and what steps they can take to improve less successful programs.

Government officials and the general public have an increasing expectation that schools will work to reduce substance abuse among adolescents. Although government and private agencies have seen fit to provide increasingly large amounts of money to provide for substance abuse programs in our schools, there has been very little research done to determine what washington state schools are currently doing 
in this area, and the extent and characteristics of these programs.

More than 2.5 million dollars was distributed to Washington State schools by OSPI during the 1987-88 school year for the express purpose of planning for and implementing substance abuse programs that include intervention activities.

This descriptive, multiple-case stuay is an effort to determine how Washington state's public high schools have implemented substance abuse intervention programs and why some programs are particularly successful or relatively unsuccessful in identifying students who are harmfully involved with alcohol and/or other drugs and referring them to appropriate services. Information obtained through this descriptive multiple-case study will be made available to educators and government officials alike in order to help them in their efforts to improve the effectiveness of substance abuse intervention programs in our secondary public schools. 
CHAPTER II

REVIEW OF RELATED IITERATURE

During the last twenty years, much has been written about substance abuse among our young people and substance abuse education in our schools. Nancy Reagan's Chemical People Project in 1983, and President Reagan's subsequent declaration of war on drugs, brought increased attention to student substance abuse and substance abuse education efforts in our schools. This increased attention resulted in a veritable explosion of recent articles and reports regarding student substance abuse, substance abuse education in our schools and other related issues.

In conducting my review of the literature, I carefully examined resources available through the Educational Resources Information Center (ERIC), numerous professional journals, dissertation abstracts, publication lists from the United states Department of Education, publication lists from the National Institute on Drug Abuse, the National Clearing House for Alcohol and Drug Information, the Guide to Periodical Literature and numerous drug education professionals.

I have organized this review to examine the following three topics: 
1. Student substance abuse.

2. Problems related to student substance abuse.

3. Substance abuse education programs.

\section{STUDENT SUBSTANCE ABUSE}

Young people who abuse alcohol and/or other drugs have no social, economic or gender distinctions. students who abuse alcohol and/or other drugs can be rich or poor, urban or rural, from a private school or ghetto school; however, the abuse of alcohol and/or other drugs by students does vary by age level (Alibrandi, 1985) .

Table I illustrates the degree of drug use among high school seniors from the classes of 1975 through 1987. These numbers were gathered in annual nationwide surveys conducted for the National Institute on Drug Abuse (NIDA) by the University of Michigan Institute for Social Research. The 1987 survey involved more than 16,000 high school seniors from public and private schools.

It should be noted that approximately $20 \%$ of all high school age youth drop out of school before their senior year. Results of the NIDA survey are therefore somewhat conservative because adolescents who are not being surveyed because they have aropped out typically have higher rates of alcohol and/or other drug use as compared with students who are in school (Anderson, 1987). In their review of the literature, Wolford and Swisher (1986) affirm the validity 
of self-reported student drug use surveys. However, Wolford and Swisher also state that student drug use surveys may underestimate the actual scope of adolescent drug use because individuals who are likely to be the heaviest drug users, including school dropouts, transients and those living in institutional settings are not included.

\section{TABLE I}

HIGH SCHOOL SENIOR DRUG USE: 1975-87

TRENDS IN LIFETIME PREVALENCE PERCENT WHO EVER USED

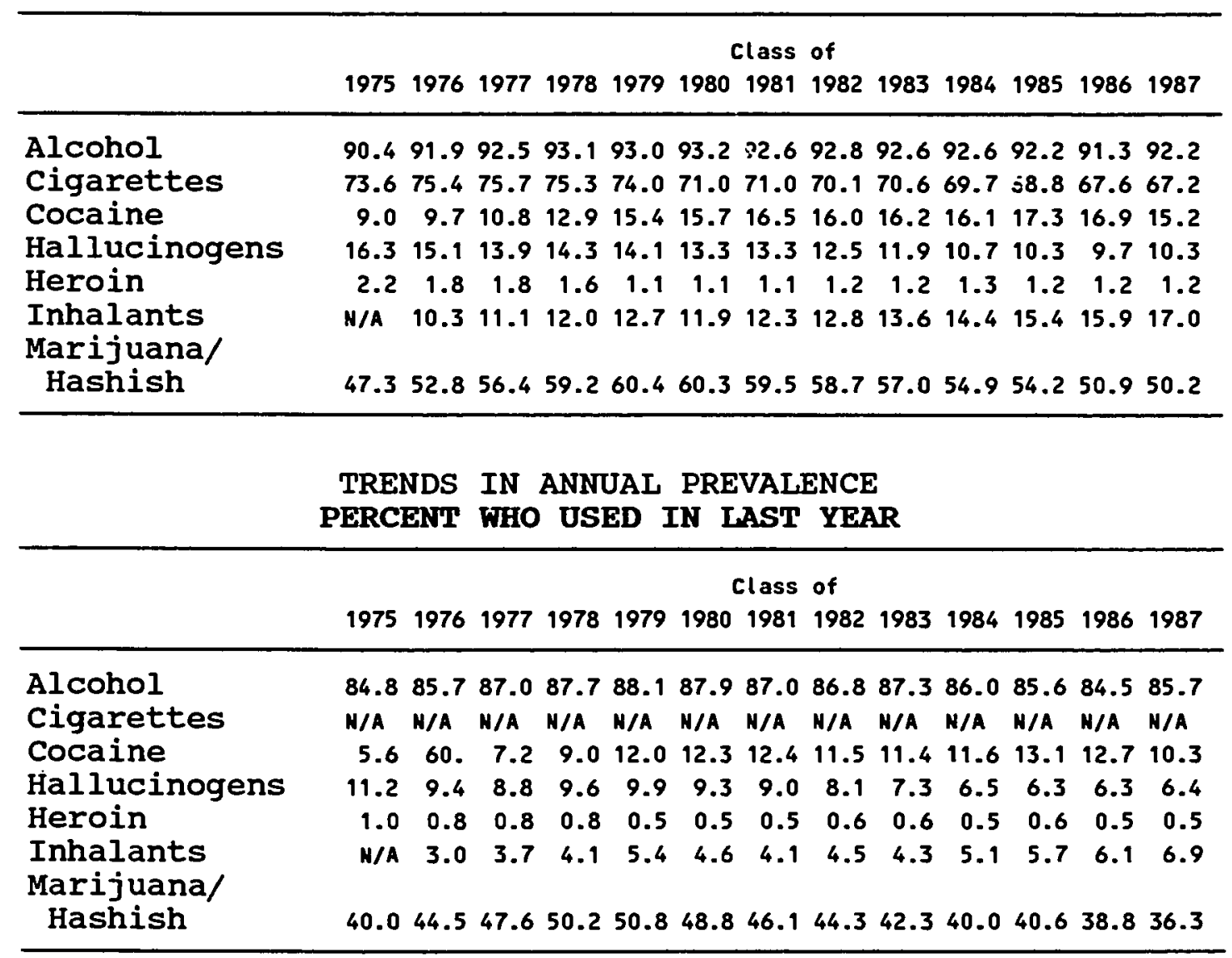


TABLE I

HIGH SCHOOL SENIOR DRUG USE: 1975-87 (continued)

TRENDS IN 30-DAY PREVALENCE

PERCENT WHO USED IN PAST MONTH

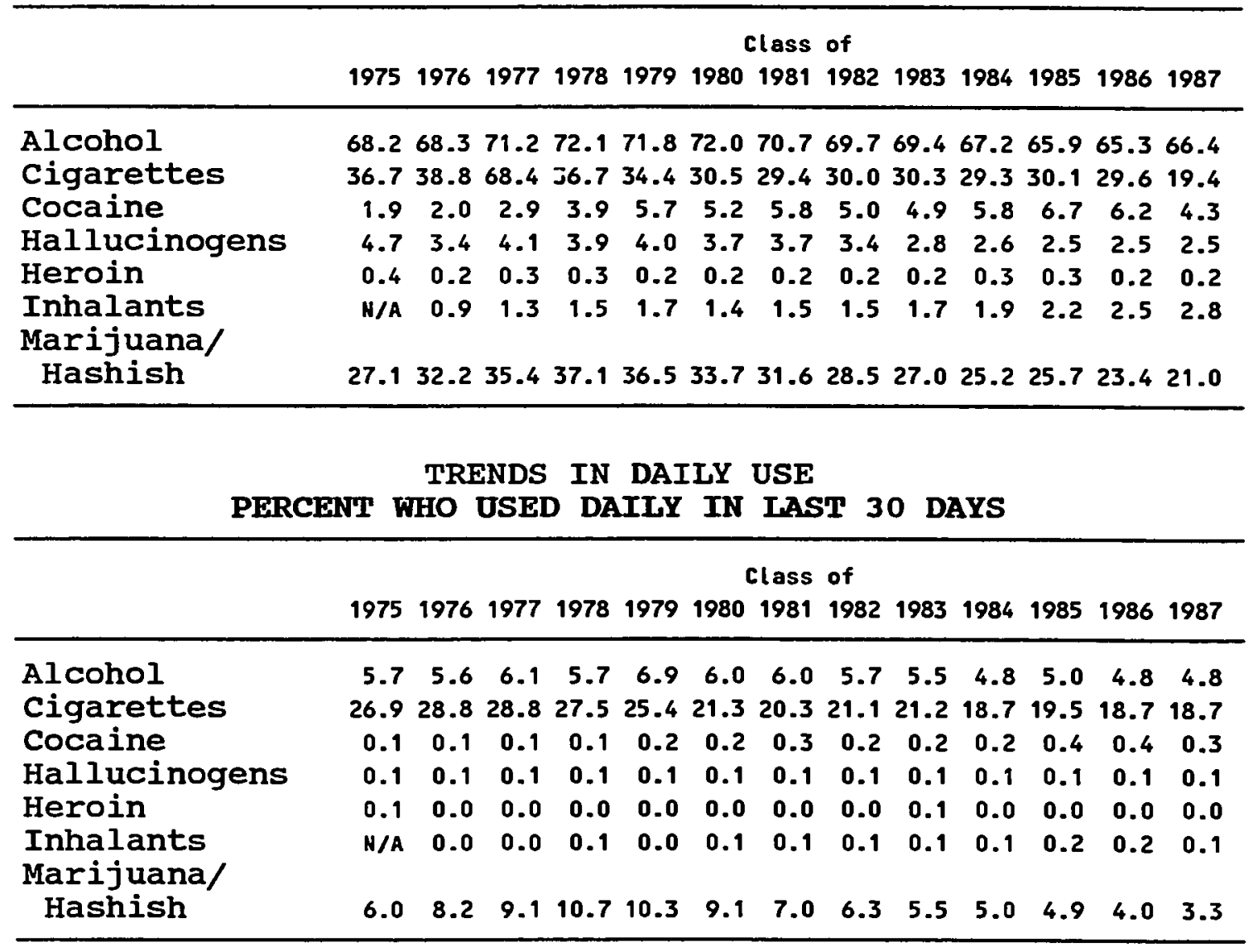

Terms: Ever Used: Used at least one time

Used in the Last Year: Used at least once in the 12 months prior to the survey

Used in Past Month: Used at lease once in the 30

Used Daily: Used 20 or more times in the month before the survey

(National Institute on Drug Abuse, 1988)

The 1987 survey shows us that approximately $92 \%$ of high school seniors have used alcohol. This represents a percentage of alcohol use among high school senior classes 
that has remained relatively constant for the past 12 years. More than two-thirds of the seniors of 1987 have used cigarettes, while more than half have used marijuana and almost one in six have used cocaine. Although these figures represent a slight decrease in student use of cigarettes and marijuana during recent years, these figures have remained alarmingly high for more than a decade. More than two-thirds of the senior class for 1987 used alcohol at least once a month, and almost one in twenty students used alcohol on a daily basis. Almost one in twenty used cocaine on a monthly basis while more than one in five high school seniors used marijuana on a monthly basis. Various local and state student drug use surveys confirm these high levels of student drug use.

A longitudinal study sponsored for the senior classes of 1975 to 1987 concluded that most student drug usage peaked around 1979 and has remained fairly stable, although student use of cocaine has continued to increase (NIDA, 1988) .

The recent rise in the popularity of cocaine among students has generated considerable public concern and attention. Increasing quantities of imported cocaine have resulted in lower prices and purer forms of the substance. Lower prices make cocaine more readily available to students and other low income groups who could not previously afford to maintain the use of cocaine. 
Another important change in the widespread availability of cocaine is the recent innovation of rock cocaine, commonly referred to as "crack cocaine." Crack cocaine is a form of cocaine that can be ingested by smoking, so it is much more readily used by young people then cocaine that has to be snorted or injected (Brower and Anglin, 1987).

of the high school seniors who reported using marijuana in $1984,4.3 \%$ indicated that they began using it by the sixth grade. This is congruent with other research that identified a growing number of elementary school students who are now experimenting with alcohol and/or other drugs (Johnston, O'Malley and Bachman, 1985).

A 1986 study of fifth grade students in the seattle Public Schools found that $32 \%$ of the fifth grade students surveyed knew someone who had tried marijuana. of these fifth grade students, $10 \%$ indicated that they could get marijuana if they wanted to and $3 \%$ indicated that they had smoked marijuana. Approximately $22 \%$ of the students surveyed said that they have used alcohol (Hopkins, 1986).

The National clearing House for Alcohol and Drug Information (1987) reports that the percentage of students who are using alcohol and/or other drugs has more than tripled over the last two decades. In the early 1960's, for example, marijuana use among 13 year old students was almost nonexistent, but in 1987, one in six 13 year old students reported that they have tried marijuana.

A California survey of alcohol and drug use among 
junior high and high school students (California Commission, 1986), found that nearly $58 \%$ of the seventh grade students surveyed said that they had used alcohol. Approximately $85 \%$ of the eleventh grade students surveyed said that they had tried alcohol. More than half of the eleventh grade students surveyed said that they had tried illegal drugs, with 18\% of them indicating that they had tried cocaine. When releasing the statewide survey, California state Attorney General John K. Van de Kamp said,

The rising tide of drug and alcohol abuse among California teenagers makes them a generation at risk. I have warned repeatedly that we must reach these kids right now or make room for them in our jails and detox centers a decade from now. We've known the problem is serious. We have not known for sure just how serious until now. (California Commission on the Prevention of Drug and Alcohol Abuse, 1986, p. 1)

In 1986, the oregon Department of Human Resources released a report on the prevalence of drug use among eighth and eleventh grade students in the state of oregon during the 1985-86 school year (Oregon Department of Human Resources, 1986). The report contained the following data:

27.7\% of eighth grade students have used alcohol. 91.4\% of eleventh grade students have used alcohol. $27 \%$ of eighth grade students have used marijuana. $56 \%$ of eleventh grade students have used marijuana. 9.4\% of eighth grade students have used cocaine. 22.6\% of eleventh grade students have used cocaine. $2.2 \%$ of eighth grade students use marijuana daily. $12.1 \%$ of eighth grade students use marijuana monthly. 
$28.6 \%$ of eleventh grade students use marijuana monthly.

$38.3 \%$ of eighth grade students use alcohol monthly. $59.6 \%$ of eleventh grade students use alcohol monthly.

In December, 1985, students in the Yakima Public Schools in Washington state participated in a large scale survey about alcohol and other drug use (Hazelden Health Promotion, 1986). A total of 1,113 students in the eighth, tenth and twelfth grades were included in the sample. The results of the survey were as follows:

69\% of eighth grade students have used alcohol. 88\% of tenth grade students have used alcohol. 92\% of twelfth grade students have used alcohol. 51\% of twelfth grade students have driven after drinking in the past 12 months.

$28 \%$ of eighth grade students have used marijuana.

$50 \%$ of tenth grade students have used marijuana. 63\% of twelfth grade students have used marijuana. 8\% of eighth grade students have used cocaine. $17 \%$ of tenth grade students have used cocaine. $28 \%$ of twelfth grade students have used cocaine. Former U. S. Department of Education Secretary, william Bennett, in his book What Works, schools without Drugs (1987), asserts that:

Americans have consistently identified drug use among the top problems confronting the nation's schools. Yet many do not recognize the degree to which their own children, their own schools, and 
their own communities are at risk. Research shows that drug use among children is ten times more prevalent than parents suspect. In addition, many students know that their parents do not recognize the extent of drug use and this leads them to believe that they can use drugs with impunity. School administrators and teachers often are unaware that their students are using and selling drugs, frequently on school property. (Bennett, 1987, p. 3)

This report further asserts that the United states has the highest rate of drug use of any industrialized nation. The report gives the comparison that our drug problem here in the United states is ten times greater than the drug problem in Japan. The report also cites a recent study in which $57 \%$ of the teenagers contacting a cocaine hotline indicate that they bought most of their drugs at school. one-third of the marijuana users in the study reported smoking marijuana at school. According to the study, two-thirds of the seniors, who reported that they used amphetamines during the past year, said that they have taken them at school.

An Associate Director of the American Council for Drug Education states that substance abuse has reached epidemic proportions among our school aged youth, and describes a recent Weekly Reader's study showing approximately one-third of the fourth graders surveyed said that alcohol was a major problem among their classmates (Rosiak, 1987). In May 1987 's Kappan Special Report, Richard Hawley links student drug use with the American classroom:

When we consider that the metabolites of some commonly abused drugs, such as marijuana, remain active in the user's system for weeks, the implications for in school behavior and performance grow 
ominous. In fact, in light of the figures for recent heavy drinking reported by the class of 1985 (45\% of boys, $25 \%$ of girls), it seems statistically unlikely that on any given day there would be many American classrooms without several drug altered students glassily meeting their teacher's expectant gazes. (Hawley, 1987, p. 2)

In addition to the numerous substance abusing students we have in our classrooms, research indicates that one out of every three students lives in a family in which there is substance abuse such that they are harmfully affected, even if they are not personally abusing alcohol and/or other drugs (Downing and Walker, 1987).

PROBLEMS RELATED TO STUDENT SUBSTANCE ABUSE

Drug Education has emerged as a leading concern among educators, students, parents, government agencies and members of the community alike. our local and national media regularly tell us about the tragic consequences of drug related criminal activity such as gang shootings, drunken driving fatalities, robberies, assaults, domestic violence, child abuse and sexual assault. Other tragic and costly consequences of substance abuse in our society include school dropouts, medical health problems and lost potential among our young people.

studies report that drunken driving accidents are the leading cause of death and injury among teenagers (National Institute of Drug Abuse, 1987). H. H. Mitchell, M.D. (1968), in a report prepared for the Rand Corporation, cites 
the significant relationship between increasing blood alcohol concentrations and the increasing risk of having an accident. Students who are harmfully involved with drugs also have a high rate of suicide. In 1982 there were more than 5,000 student suicides, a trend that is increasing (Alcohol, Drug Abuse and Mental Health Administration, 1985).

According to the U. S. Department of Education, student substance abuse is closely tied to truancy and dropping out of school:

High school seniors who are heavy drug users are more than three times as likely to skip school as nonusers. About $1 / 5$ of heavy users skip three or more school days a month, more than six times the truancy rate of nonusers. In a Philadelphia study, dropouts were almost twice as likely to be frequent drug users as were high school graduates; four in five dropouts used drugs regularly. (Bennett, 1986, p. 10)

The U. S. Department of Education also reports that student substance abuse is associated with crime and misconduct that disrupt the maintenance of an orderly and safe school:

Drugs not only transform schools into market places for dope deals, they also lead to the destruction of property and to classroom disorder. Among high school seniors, heavy drug users were $2 \frac{1}{2}$ times as likely to vandalize school property and almost 3 times as likely to have been involved in a fight at school as nonusers. students on drugs create a climate of apathy, disruption, and disrespect for others. For example, among teenage callers to a national cocaine hotline, $44 \%$ reported that they sold drugs and $31 \%$ said that they stole from family, friends, or employers to buy drugs. A drug ridden environment is a strong deterrent to learning not only for drug users, but for other students as well. (Bennett, 1986, p. 10) 
In general, adolescents who use alcohol and/or other drugs are also involved in more delinquent activities, such as trouble with school and the police. Several studies have demonstrated a relationship between adolescent substance abuse and juvenile delinquency.

In summarizing a 1976 study conducted by the Alcoholism Council of orange County, California, Tom Alibrandi, in his book Young Alcoholics, says:

FACT: According to the orange county, California, Criminal Justice Council, the juvenile arrest rate is nearly $2 \frac{2}{2}$ times the adult arrest rate.

FACT: A member of the orange county public Defender's office stated publicly that virtually every juvenile his office defended in 1976 claimed to have been drinking alcohol when they committed the crime for which they were being tried.

FACT: A recent poll conducted by the Director of Joplin Boys Ranch (an orange County Juvenile Detention camp) showed that 98 out of 100 boys in camp were drinking when they committed the offense that put them in closed care. (Alibrandi, 1985, p. vii)

This information is consistent with national statistics showing that nearly half of the convicted jail inmates were under the influence of alcohol when they committed their crime, and a significant portion of the remainder were under the influence of some other drug (National clearing House for Alcohol and Drug Information, 1985).

In a 1987 article for the National Association of Secondary School Principals' bulletin, John Rosiak, Associate Director of the American Council for Drug Education, discussed how drug use may adversely affect students' family relationships. 
Socially, drug use often damages already fragile relationships between the adolescent and other family members. Drug users avoid confronting normal problems that occur in adolescence, fail to learn from mistakes, and avoid new challenges. Coming to grips with difficult decisions about values and making important distinctions between what is good and healthy and what is bad and unhealthy are made even more difficult in the drugged state. Because drug use offers immediate gratification with little or no effort, the user does not develop either an appropriate tolerance for frustration, or the capacity for deferring pleasure. (Rosiak, 1987, p. 129)

Research also emphasizes the developmental dangers faced by young people who are abusing alcohol and/or other drugs. Jessor and Jessor's longitudinal study (1977), on the effects of substance abuse on psycho-social development and its relationship to problem behavior reported that student behavior can be adversely affected by the abuse of alcohol and/or other drugs. Their research findings indicate that the psycho-social maturation development processes of adolescence can be significantly impaired by the abuse of alcohol and/or other drugs.

Richard Hawley explains how the problems caused by students who are abusing alcohol and/or other drugs extend beyond the abusing students themselves and their families:

The destructive effects of student drug use on learning and on the conduct of schooling in general are by no means limited to the users themselves. Even a few drug-enervated students in a classroom will change the learning climate for everyone. Drug altered children are largely impervious to classroom business; teachers are apt to see them as unprepared, preoccupied, hostile. such students - and again, it only takes a few - tend to shut teachers down and push them toward less effective teaching. Teaching drugged children is like acting or singing in the presence of hecklers or hosting a party at 
which a few of the guests are bent on having a bad time. A competent teacher who works hard trying to engage chemically impaired nervous systems is working against the grain. It is no coincidence that "teacher burnout" - the term itself is derived from the drug culture - should have surfaced as a national issue directly in the wake of epidemic student drug use. (Hawley, 1987, p. 2)

This information provides a broad view on the negative effects of student substance abuse. When we contemplate substance abuse education programs in our schools, it is important to remember that we develop programs to serve more than just the abusing students and their family. Substance abuse education programs also serve to help school staff and the other students who are victims to the fallout caused by the substance abusing students' behavior.

\section{SUBSTANCE ABUSE EDUCATION PROGRAMS}

During the 1960's, 70's and early 80's, substance abuse education programs were almost exclusively prevention activities that consisted primarily of films and other media materials that displayed the tragic and extreme consequences of alcohol and/or other drug abuse. According to Tom Alibrandi, these efforts had little effect on influencing students who were abusing alcohol and/or other drugs:

Most alcohol abusing kids drink for the effects and are simply not intimidated by what might or might not happen to them 20 years hence. It makes no sense to expect them to identify with a film about the physical, emotional or moral manifestations of long years of hard drinking. This is as logical as expecting an adolescent to react to the anti-smoking campaign in which a middle aged movie star appears on $\mathrm{TV}$ and announces that he has quit 
smoking, apparently with as much inner turmoil as deciding to brush his teeth. To that kind of "education" a young person will retort, "When I get to be his age, I'll quit too." (Alibrandi, 1985, p. 49)

Drug educators throughout the country agree that shock efforts are not the answer to our substance abuse education needs, and that prevention efforts in general have had very little success in reducing student substance abuse (Alibrandi, 1985; Anderson, 1987; Johnston, et al., 1982; Goodstadt, 1980) .

Dr. William Hansen, from the Institute for Health Promotion and Disease Prevention at the University of Southern California, has also questioned the value of prevention programs:

One of the most common prevention programs adopted by schools educate students about the consequences of using alcohol and other drugs. There is no clear evidence that information programs or programs which use information to raise fear are effective in preventing the onset of substance abuse behaviors. Indeed there is some evidence that providing particular kinds of information, such as information about what drugs look and smell like, may actually foster experimentation with drug use. Nonetheless, many lay people, teachers, and health professionals think of just this sort of program (i.e., one which tcaches information about consequences of use, especially information laden with fear) when given the task of inventing or recommending a prevention program. (Hansen, et al., 1988, p. 145)

In his review of the literature, Goodstadt (1980) found that many studies of prevention programs showed negative results in that there was more student experimentation with drugs after the prevention programs. Many researchers report that the more substance education 
information that students are exposed to, the more likely these students are to use drugs. In their book Drug Education: Results and Recommendations, Blum, Blum and Garfield (1976) report that some experimental substance abuse education programs appear to have caused increased drug experimentation. stewart (1974) found that once high school students were educated about drugs, they exhibited less fear of using them.

Substance abuse education prevention programs that utilize the information approach assume that students use alcohol and/or other drugs because they lack information about the dangers of alcohol and drug use. such curriculums are based on the assumption that once students receive irformation about the dangers of alcohol and drug use, their attitudes and behaviors will change and their use of alcohol and/or other drugs will be prevented or reduced. Information curriculums do often increase a student's knowledge about drugs, but there is overwhelming evidence that information curriculums are not successful in changing students' attitudes or behaviors regarding the use of alcohol and/or other drugs (Blum et al., 1976; Goodstadt, 1978; Hanson, 1980; Kinder, et al., 1980; Swisher, 1974). Research studies regarding the effectiveness of prevention programs based on enhancing student decision making skills and social skills are less conclusive. Goodstadt, sheppard and chan (1982) reported that the 
results from various substance abuse education prevention programs that teach decision making skills tend to be ambiguous, failing to show a direct link to reduced drug use. On the other hand, some substance abuse education prevention programs that teach social skills to resist peer pressures have yielded encouraging results (Ellickson, 1984; Ellickson, et al, 1984; Evans, 1981).

Substance abuse education prevention programs based on the development of skills to resist peer pressure incorporate specific activities designed to help students identify the ways in which peers pressure them to use alcohol and/or other drugs. These programs also help students develop skills for countering pro-drug usage arguments, as well as the ability to say "no." These kinds of substance abuse education prevention programs helped form the foundation for Nancy Reagan's nationwide "Just Say No" program.

Drug educators agree that efforts to reduce and eliminate student substance abuse require comprehensive programs that include a variety of efforts. As we consider the various activities that need to be implemented in order to have a comprehensive substance abuse education program, we must consider who it is that we are trying to help.

It is important to recognize that we have students with a variety of needs related to drug abuse. Students in our schools include: children with no drug involvement, children who casually experiment with drugs, children who are abusing, children who are chemically dependent, children with other special needs that are drug related, children who live in chemically dependent homes, and children who 
are recovering from chemical dependency. If our program is to be comprehensive, it must be designed to help all of these children (Herberg, 1987, p. 7).

Tom Griffin and Roger svendsen of the Hazelden Foundation, in their 1986 book The Student Assistance Program, divide the activities of a comprehensive substance abuse education program into three primary areas: prevention activities, health promotion activities and response activities (intervention activities).

Prevention deals with specific problems and is directed, as the word suggests, toward those individuals who do not currently have problems. There are several categories of prevention efforts that are essential:

1. Programs that provide important information young people need to make healthy decisions. While information alone is not likely to prevent adolescent problems, it is an important part of a prevention effort.

2. Development of essential social skills young people need in order to make these decisions.

3. Activities that help people establish and maintain healthy lifestyles. These activities range from lifetime supports to non-chemical "straight" parties following school events.

4. Social policy measures such as drunk driving laws, drinking age laws, and school policies on the use of tobacco by students, and other regulations which effect behavior.

5. Establishment of standards for safe, healthy, and appropriate behavior within families, social institutions, and the community.

Health promotion is more general and focuses on the healthy development of individuals, rather than responding to specific adolescent problems and concerns. Health promotion is a process in which each person's self-worth is acknowledged and nurtured, while personal and social support are developed and strengthened. Health promotion efforts can be integrated easily into the ongoing curriculum and activity's programs of most schools to form the cornerstone of a health program. These efforts include the following: 
1. To acknowledge and nurture each person's self-worth independent of performance in an activity.

2. To increase self-awareness in students toward an understanding of the feelings and emotions they experience.

3. To develop personal, social, and spiritual support systems with strong peer support.

4. To focus on healthy lifestyles that include lifelong sports and activities, good nutrition, and stress management.

Response involves providing assistance to persons and families who are experiencing problems. The primary role of the school in the broad area of response is having a process and procedures for identifying and responding to problems among students; and providing support to the student both during and after the prescribed program, and facilitating its smooth return into the school. The process of responding to problems within the school include several steps:

1. Observing and identifying educational behaviors of concern.

2. Documenting the specific behaviors of concern.

3. Sharing concerns with student by a concerned staff member.

4. Referring for assistance when appropriate which may or may not include a diagnostic evaluation for chemical or mental health problems.

5. Providing aftercare support upon return to their community for those who undergo treatment or therapy. (Griffin and Svendsen, 1986, pp. 8-9)

Various forms of intervention activities have enjoyed relative success (Flood and Morehouse, 1986; Anderson, 1987).

After several years of working with students abusing alcohol and/or other drugs, Gary Anderson (1987) concludes that intervention programs are the most effective means by which we can address the problems of students related to substance abuse.

The substance abuse intervention model that Anderson 
proposes is called a "student assistance program." The student assistance program is also the model that the Hazelden Foundation identifies as being most effective in helping students who are harmfully involved with alcohol and/or other drugs (Griffin and Svendsen, 1986).

In 1987, the office for Substance Abuse Prevention (OSAP), the National Association of state Alcohol and Drug Abuse Directors (NASADAD) and the National Prevention Network (NPN) sponsored a project to identify twenty exemplary drug education programs in the United states (Office for Substance Abuse Prevention, 1987). The project was entitled "Helping Communities Help Themselves, Twenty Exemplary Projects." One of the programs selected was the New Holstein Public School's student Assistance Program in New Holstein, Wisconsin.

The New Holstein school system serves about 1,600 students in grades $\mathrm{k}-12$, and its student assistance program has been in operation for more than five years. School district officials attribute to the student assistance program a decrease in disciplinary referrals, an increase in attendance and a significant increase in grade point average for students serviced by the student assistance program. The New Holstein Student Assistance Program has an Administrative coordinator in each building who is responsible for managing the program. The coordinators work with central office staff, teachers, students, community organizations 
and other agencies in order to effectively operate the program. Teachers are trained to identify the early warning signs for students who are harmfully involved with alcohol and/or other drugs. Students identified as having problems with alcohol and/or other drugs are then referred to special services including counseling, school based support groups, as well as treatment for those identified as being chemically dependent. In a five year period, 491 students were referred to the student assistance program, and 474 of these students became involved in a support group.

\section{SUMMARY}

In conclusion, my review of the literature related to substance abuse education shows that educational administrators and drug education specialists agree that the problem we face is enormous and that schools do indeed play an essential role in fighting the problems of student substance abuse. The literature also shows that although we are continuing to increase our commitment of resources to student substance abuse problems, it does not appear that we have made any substantive improvements in reducing student substance abuse during the last ten years.

Prevention efforts have not significantly reduced student abuse of alcohol and/or other drugs. There is, however, evidence that intervention activities disrupt student abuse of alcohol and/or other drugs (Griffin and 
Svendsen, 1986; Anderson, 1987). Intervention activities are a critical part of any school's substance abuse program; and intervention activities are an especially critical part of any substance abuse program in our secondary schools because research indicates that most of our secondary students are already involved in the use of alcohol and/or other drugs. 
CHAPTER III

\section{METHODS AND PROCEDURES}

This study of the identification and referral components of substance abuse intervention programs in Washington state's public high schools was intended to address the following purposes:

Purpose I. The first purpose of this study is to identify and describe the characteristics of public high school substance abuse intervention programs that are successful in identifying students harmfully involved with alcohol and/or other drugs and referring these students to appropriate services.

Purpose II. The second purpose of this study is to identify and describe the characteristics of public high school substance abuse intervention programs that are unsuccessful in identifying students harmfully involved with alcohol and/or other drugs and referring these students to appropriate services.

Purpose III. The third purpose of this study is to determine the characteristics of a public high school substance abuse intervention program that enable it to be successful in identifying students harmfully involved with alcohol and/or other drugs and referring them to appropriate 
services by comparing and contrasting the characteristics of successful and unsuccessful public high school substance abuse intervention programs.

In selecting the methodology for my research, I reviewed the various alternatives including historical studies (archival analysis), case studies, experimental studies and surveys. After reviewing the various alternatives, I decided the best methodology to use was a descriptive, multiple-case study.

In his book Case Study Research Design and Methods, Yin says:

We can identify some situations in which all research strategies might be relevant (such as exploratory research), and other situations in which two strategies might be considered equally attractive (such as how and why Reagan got elected). We can also use more than one strategy in any given study (for example a survey within a case study or a case study within a survey). To this extent, the various strategies are not mutually exclusive. But we can also identify some situations in which a specific strategy has a distinct advantage. For the case study, this is when: a "how" or "why" question is being asked about a contemporary set of events, over which the investigator has little or no control. (Yin, 1987, p. 20)

The study of the identification and referral components of substance abuse intervention programs in Washington State's public high schools during the 1987-88 school year is definitely a contemporary situation.

This descriptive, multiple-case study examines substance abuse intervention programs as they existed in Washington state's public high schools during the 1987-88 
school year. The multiple sources of evidence used includes surveys, open-ended staff and student interviews and various documents. An examination of the substance abuse intervention programs in Washington state's public high schools does not lend itself to an experimental research methodology because the researcher has no control, nor does the researcher seek any control, over any behaviors or activities of students or school personnel. The study is, instead, an examination of substance abuse intervention programs that existed during the 1987-88 school year. A survey methodology, by itself, would not provide the wide range of information necessary for a comprehensive examination of the characteristics of successful substance abuse intervention programs because the alternatives are too varied, and only open-ended interviews will allow for sufficient data gathering. The need for a contemporary and comprehensive description of the characteristics that contribute to a substance abuse intervention program's success make a historical methodology inappropriate also.

\section{CASE STUDIES}

To design my case study, I used the research strategies and methodology presented by Robert Yin (1987) in his book Case Study Research: Design and Methods. Yin defines a case study as an empirical inquiry that:

1. Investigates a contemporary phenomena within its 
real-life context when the boundaries between phenomenon and context are not clearly evident; and

2. In which multiple sources of evidence are used. (Yin, 1987, p. 23)

Yin also subdivides the case study into four basic types: holistic single-case studies, embedded single-case studies, holistic multiple-case studies and embedded multiple-case studies. Whether or not a study is a singlecase or multiple-case is dependent upon the unit of analysis in the study. In this study the units of analysis are several different public high school substance abuse intervention programs; therefore, this study is a multiplecase study. Another differentiation made by $Y$ in is whether or not the study is holistic or embedded. Holistic studies pool the results obtained when studying each unit of analysis as opposed to an embedded design where results of the study for each unit of analysis are not pooled, but rather the data are used only to interpret the success and operations of that particular school's program. Given these operational definitions, the methodology designed for this study is that of an embedded multiple-case design.

In developing the embedded multiple-case design, Yin emphasizes the importance of using replication logic as opposed to sampling logic. Yin explains that every case in the multiple-case study should serve a specific purpose within the overall scope of inquiry, and that the analysis 
of each case must follow cross-experiment rather than within-experiment design and logic. Yin says that:

Each case must be carefully selected so that it either:

a. predicts similar results (a literal replication) or

b. produces contrary results but for predictable reasons (a theoretical replication).

Thus, the ability to conduct six or ten case studies, arranged effectively within a multiple-case design, is analogous to the ability to conduct six to ten experiments on related topics; a few cases (two or three) would be literal replications, whereas a few other cases (four to six) might be designed to pursue two different patterns of theoretical replications. If all the cases turn out as predicted, the six to ten cases and the aggregate would have provided compelling support for the initial set of propositions. (Yin, 1987, p. 49)

A survey of Washington state public high school substance abuse intervention programs identified eight public high schools with particularly successful substance abuse intervention programs; as well as the identification of four public high school substance abuse intervention programs that were relatively unsuccessful. Although data from each of these units of analysis were collected and interpreted individually, the cross analysis of these data illustrates literal and theoretical replication.

\section{RESEARCH DESIGN}

Yin (1987) identified five components of a research design that are especially important for case studies:

1. A study's questions.

2. Its propositions. 
3. Its units of analysis.

4. The logic linking the data to the propositions.

5. Criteria for interpreting the findings.

I addressed each of these five recommended components as I developed the research design for my multiple-case study that examined the identification and referral components of substance abuse intervention programs of Washington state's public high schools.

\section{STUDY QUESTIONS}

study questions were used to collect descriptive information about the substance abuse intervention programs for each of the selected cases (eight successful public high school substance abuse intervention programs and four relatively unsuccessful public high school substance abuse intervention programs).

I developed the study questions based on my review of the related literature and my own professional knowledge and experience in the substance abuse intervention field. The following study questions will help provide information regarding various components of a substance abuse intervention program such as: formal drug education policies; staff training on drug education issues and intervention skills; formal curriculum and student instruction; central office administration and building administration support for the program; community support for the program, staff time to 
administer the overall program, a formalized identification strategy, a formalized referral process, a formal re-entry (recovery) program and the availability of formal assessment services for students.

1. What kinds of formal drug education instruction programs exist in the school at each grade level?

2. What kind of formal program does the school have for identifying students who are harmfully involved with alcohol and/or other drugs?

3. Which school staff members participate in the identification of students who are harmfully involved with alcohol and/or other drugs?

4. What kind of formal training do staff members receive to help them identify students who are harmfully involved with alcohol and/or other drugs?

5. Which school staff members are involved in referring students who are harmfully involved with alcohol and/or other drugs to an appropriate service?

6. What kind of formal training do staff members receive to help them refer students who are harmfully involved with alcohol and/or other drugs to appropriate services?

7. Does the school have a student peer assistance program related to substance abuse among students?

8. Does the school have an established process for helping students obtain formal assessment relative to 
alcohol and/or other drug abuse and chemical dependency?

9. Does the school have an established re-entry program for students returning after having received counseling or treatment for alcohol and/or other drug abuse?

10. During the 1987-88 school year, did the school have a formal written policy regarding student alcohol and/or other drug abuse, and are students aware of it?

11. How does the school's drug education intervention program utilize outside agencies and organizations?

12. What are the most important aspects of your school's drug education intervention program?

13. How does central office administration and building administration support the school's drug education intervention program?

14. How does the community support the school's drug education intervention program?

15. How is the school's drug education intervention program managed (administered)?

16. How can the school's drug education intervention program be improved?

\section{PROPOSITIONS}

Yin (1987) explains that although study questions capture what the researcher may be interested in answering, study questions do not necessarily point to what should be studied. Formal propositions, on the other hand, will force 
the researcher to move in the right direction. Yin says that study propositions should reflect important theoretical issues, as well as tell the researcher where to look for relevant evidence. Based on my review of the literature, in combination with the established study questions, I have developed the following propositions to further narrow the focus of my study.

Proposition I: successful public high school substance abuse intervention programs share certain common characteristics that enable them to successfully identify students who are harmfully involved with alcohol and/or other drugs and refer these students to appropriate services.

Proposition II: Unsuccessful public high school substance abuse intervention programs lack certain common characteristics that prevent them from being able to successfully identify students who are harmfully involved with alcohol and/or other drugs and refer these students to appropriate services.

Proposition III: Staff who operate and manage successful public high school substance abuse intervention programs share common ideas and recommendatiors regarding what leads to the improvement and success of a high school substance abuse intervention program. 


\section{UNITS OF ANALYSIS}

The unit of analysis for this multiple-case study is the public high school substance abuse intervention program of twelve selected Washington state high schools. Sub-units of analysis within the multiple-case study include the various components and attributes of a substance abuse intervention program. Examples of these sub-units include: formal drug education policies; staff training on substance abuse issues and intervention skills; formal curriculum and student instruction; central office administration and building administration support for the program; community support for the program, staff time to administer the overall program, a formalized identification strategy, a formalized referral process, a formal re-entry (recovery) program and the availability of formal assessment services for students.

LOGIC LINKING THE DATA TO THE PROPOSITIONS

For each individual case within the multiple-case study, data were collected using an established set of study questions. These data create a comprehensive description for each school's substance abuse intervention program. A cross-case analysis identified common characteristics among successful public high school substance abuse intervention programs, as well as common characteristics among relatively unsuccessful public high school substance abuse intervention 
programs. Study Propositions 1 and 2 served as the primary focus for these cross-case analysis comparisons.

\section{CRITERIA FOR INTERPRETING THE FINDINGS}

The purpose of this study was to: (1) identify and describe the characteristics of public high school substance abuse intervention programs that are successful in identifying students harmfully involved with alcohol and/or other drugs and referring those students to appropriate services, (2) identify and describe the characteristics of public high school substance abuse intervention programs that are relatively unsuccessful in identifying students harmfully involved with alcohol and/or other drugs and referring those students to appropriate services and (3) determine the characteristics of a public high school substance abuse intervention program that enable it to be successful in identifying students harmfully involved with alcohol and/or other drugs and referring them to appropriate services by comparing and contrasting the characteristics of successful and unsuccessful public high school substance abuse intervention programs.

When each of the selected successful cases demonstrated the same characteristic, a commonality was determined to exist. similarly, when each of the selected relatively unsuccessful cases demonstrated the same characteristic, a commonality was determined to exist. These commonalities 
are identified through a cross-case analysis. Comparisons and contrasts of the commonalities among the successful and unsuccessful substance abuse intervention programs is discussed using data obtained through the cross-case analysis and the individual case reports.

VALIDITY AND RELIABILITY

Yin identifies four tests that enable the researcher to establish a case study's validity and reliability. Yin says that:

Because a research design is supposed to represent a logical set of statements, we also can judge the quality of any given design according to certain logical tests. Whether one is doing case studies or any other type of social science, four tests are relevant (Yin, 1987, p. 35).

These four tests are:

1. Construct validity,

2. Internal validity,

3. External validity, and

4. Reliability.

\section{Construct validity}

One aspect of this study that helps ensure construct validity is the use of multiple sources of evidence in a manner encouraging convergent lines of inquiry. Numerous sources of evidence were used in this study including a written survey, a telephone survey, open-ended interviews with school staff and students and vaxious relevant 
documents. The surveys enabled me to develop quantitative information about the implementation of various program components in all of Washington state's public high schools. The open-ended interviews and documentary evidence enabled me to develop extensive qualitative information regarding the implementation of the case high school's substance abuse intervention programs. All of these sources of evidence were reviewed and analyzed together such that the case studies' findings were quantitative and qualitative based on the combined information from both sources. Another aspect of this study that contributes to construct validity is the chain of evidence that was established with specific procedures consistent with case study protocol.

\section{Internal validity}

According to yin (1987) the internal validity of a case study is of concern for explanatory or causal case studies only, and not for descriptive or exploratory case studies. Internal validity is designed to establish causal relationships, whereby certain conditions are shown to lead to other conditions as distinguished from spurious relationships. Concerns over possible inferences were minimal in this study because it was a descriptive multiple-case study.

\section{External validity}

This test deals with whether or not a study's findings are generalizable beyond the immediate case study. Yin 
(1987) notes that a problem lies in the very notion of generalizing to other case studies. Instead, Yin recommends that the researcher should try to generalize findings to theory analogous to the way a scientist generalizes from experimental results to theory. Although a theory must be tested through replications of the study's findings, the results from this study could be accepted for similar units of analysis (i.e., public high schools). The multiple-case (embedded) research design for this study is based upon replication logic that is analogous to the logic used in multiple-experiments. However, because this is a case study, and it is a descriptive case study, the generalizability of the findings is limited.

\section{Reliability}

While conducting this study, I have created a comprehensive database that consists of notes, correspondence, documents, surveys, audiotaped interviews, interview narratives and all relevant charts and graphs. These materials were developed and cataloged consistent with the procedures of case study protocol. Much of the case study database is contained in various computer spreadsheets in addition to the various hard copy documents and audiotapes. In conducting this study, I have followed the advice of Yin (1987) and made the steps as systematic and operational as possible. I am confident that if this study were conducted again, and if that investigator followed exactly the same 
procedures as I have documented, that investigator should arrive at the same findings and conclusions as I have.

\section{PROCEDURES}

The study is comprised of two major activities:

1. A survey of all Washington state public high school substance abuse intervention programs.

2. A comprehensive examination of the substance abuse intervention programs for twelve selected public high schools through site visitations.

The first major activity was a survey of all of Washington state's public high schools regarding their substance abuse intervention programs as they existed during the 1987-88 school year. The purpose of this survey was to determine the status of substance abuse intervention programs in Washington state's public high schools, as well as to identify eight public high schools that were particularly successful and four public high schools that were relatively unsuccessful in their ability to identify those students who were harmfully involved with alcohol and/or other drugs and refer those students to appropriate services.

The survey was developed using the total design method described by Don Dillman in his book Mail and Telephone Surveys: The Total Design Method (1978). By utilizing the total design method I was able to maximize both the quantity and quality of the survey responses. 
The initial survey (Appendix 1-A) was developed by myself in cooperation with John Hughes, Director of Drug Education for Educational Service District 114; Paul Templin, Coordinator of Technical Assistance for Community Mobilization Against Substance Abuse for Washington state's Bureau of Alcohol and Substance Abuse; and Chris Hansen, Community Services Program Manager for Washington state's Bureau of Alcohol and Substance Abuse.

The survey was then presented to Educational Service District drug education specialists and various Washington state administrators who had formerly served as secondary building administrators to determine the clarity and usefulness of the survey document. Former administrators were used so as not to contaminate the actual statewide survey.

Following these revisions, a final draft of the survey was sent to secondary school administrators and drug educators in oregon who agreed to review and respond to the clarity and utility of the survey. Oregon schools participating in the survey review include: Tigard High school in Tigard, Chenoweth High School in The Dalles, Aloha High School in Beaverton, Sunset High School in Beaverton, willamette High School in Eugene, Cascade Associates in Eugene, Columbia High in Troutdale, Gresham High in Gresham, and Hood River High in Hood River. Based on responses from these administrators a final draft of the survey document 
was prepared and presented to my doctoral committee for final review. The survey, in its final form as approved by my Doctoral Committee, appears as Appendix 1-D.

The surveys were then mailed to each of Washington State's 624 secondary public school principals including all middle schools, junior high schools, high schools and secondary alternative programs. These principals were identified using the 1987-88 Washington Education Directory. Information regarding the status of substance abuse intervention programs in washington state's public middle schools, junior high schools and secondary alternative programs enabled this researcher to examine numerous relationships that may exist between those programs and programs in the public high schools.

of the 624 schools surveyed, 302 were public high schools. The survey packets mailed included a letter of introduction and instructions (Appendix 1-E) and the survey; as well as a stamped, self-addressed return envelope. The instructions included directions to work with those individuals in the school who were most knowledgeable about that school's drug education intervention program when completing the survey. This was done to minimize the risk that always exists in a mail survey by reducing the possibilities of uneducated and inaccurate responses. Principals were asked to return the survey by october 28,1988 . 
After the initial submission deadline, schools that had not responded to the survey were sent a follow-up and thank you letter (see Appendix 1-F) with an additional survey. This letter reiterated the importance of the survey and asked again for their assistance. Those schools who had not responded by November 18, 1988 were called and reminded of the survey. To those schools who had misplaced or lost the survey, a new survey package was sent. As a result of these efforts, 536 (86\%) had been returned as of December 1, 1988. Of the 302 public high schools, 196 (65\%) schools returned their survey by December 1, 1988 .

Information from the initial survey data enabled the identification of public high schools with particularly high rates of identification and referral of students harmfully involved with alcohol and/or other drugs and public high schools that had relatively low rates. To determine a school's success rate, for the purposes of this study, the total number of students identified as being harmfully involved with alcohol and/or other drugs and referred to special services was divided by the total number of students enrolled to determine that school's success ratio. This study's assumption is that the higher the ratio, the more successful the intervention program and the lower the ratio, the less successful the intervention program.

In order to make this assumption, we must also assume, for the purpose of this study, that each public high school 
in Washington state has a similar percentage of students who are harmfully involved with alcohol and/or other drugs. The 24 public high schools not giving a response in the identification and referral section of the survey were not considered. All of the high school surveys that included information regarding identification and referral data were separated into four groups according to student enrollment. The four enrollment classifications were:

1. Those schools with less than 500 students.

2. Those schools with 500-999 students.

3. Those schools with 1,000-1,499 students.

4. Those schools with more than 1,500 students.

At least four of the most successful and at least two of the least successful schools in each of the enrollment classification were identified for follow-up telephone interviews.

A telephone interview was conducted with these schools to substantiate the accuracy of information reported on the initial survey. Questions used for this interview appear as Appendix 1-H. The telephone interview questions enabled this researcher to double check the accuracy of the survey, and determine whether or not the survey responses were consistent with the intent of this study. From these telephone interviews, eight public high schools with particularly high rates of identification and referral and four public high schools with relatively low rates of identification and referral were selected for site visitations; two successful 
schools from each enrollment classification and one unsuccessful school from each enrollment classification.

The study's second major activity was the site visitations of the twelve public high schools selected as being particularly successful or relatively unsuccessful. Eight of the site visitations were conducted personally by myself, two were conducted by John Hughes, Director of ESD 114's Drug Education Department and two were conducted jointly by Mr. Hughes and myself. During the site visitations a set of standard interview questions were asked of various staff members and students to determine again the accuracy of the initial survey instrument and to further determine the aspects of the school's substance abuse intervention program that enabled staff to (or prevented staff from being able to) identify and refer students harmfully involved with alcohol and/or other drugs. Documents were also collected during the site visitations to further evidence the schools substance abuse intervention program.

staff members interviewed were divided into two categories: (1) administrators and counselors and (2) teachers and support staff. Students interviewed included a group of students who had previously been diagnosed as being harmfully involved with alcohol and/or other drugs, and a group of students who had not been diagnosed as being harmfully involved with alcohol and/or other drugs. 
The interview forms used for the site visitation interviews are included as Appendix 1-L. The interview questions and forms were developed using Educational Research: An Introduction by Walter Borg and Meredith Gall (1983) as a guide. Interviews were designed to be semistructured such that the interview was reasonably objective with a mix of close-ended and open-ended questions. This structure permitted the respondent to give opinions, and the reasons to support their opinions. According to Borg and Gull (1983), the semi-structured interview is generally most appropriate for interview studies in education.

Prior to conducting the site interviews, John Hughes and I carefully reviewed the essential skills required of a case study investigator. According to yin (1987), the required skills of a case study investigator are as follows:

1. A person should be able to ask good questions-and to interpret the answers.

2. A person should be a good listener and not be trapped by his or her own ideologies or preconceptions.

3. A person should be adaptive and flexible, so that newly encountered situations can be seen as opportunities, not threats.

4. A person must have a firm grasp of the issues being studied, whether this is a theoretical or policy orientation, even if in an exploratory mode. Such a grasp reduces the relevant events and information to be sought to 
manageable proportions.

5. A person should be unbiased by preconceived notions, including those derived from theory. Thus, a person should be sensitive and responsive to contradictory evidence.

In addition, John Hughes and I carefully reviewed the dissertation protocol developed for this study. In the protocol I developed a standard script for introducing the interviews to staff and students. Approval to conduct the site visitations and interviews in the selected schools was obtained from the school principal and acknowledged in a thank you letter (see Appendix 1-K).

Prior to visiting the selected schools, a pilot study was conducted. The pilot study enabled me to field test my interview instruments for students and staff, as well as field test my data collection techniques for organizational documents. The pilot study was conducted at South Kitsap High School in the South Kitsap school District. The original interview instruments used in the pilot study appear in Appendix 1-J.

Interview forms for the pilot study were developed for school administration, school counselors, teachers, classified staff and students in such a fashion that the forms were related to the study questions and study propositions; and they were designed to carefully examine the characteristics of that school's drug education intervention program. 
The forms were also designed to provide for consistent data collection from the various sources and facilitate cross analysis.

Some questions on the interview forms were designed to provide information regarding documentary evidence and assist in the interviewer's observations of staff and student attitudes.

The various interview forms used in the pilot study were revised as a result of the field testing and restructured to contain additional questions that enabled this researcher to collect information that was not obtainable through the initial set of interview questions. The pilot survey forms were also restructured so as to eliminate some questions that were best integrated into other questions. As it was determined that teachers and support staff could be best interviewed together, the interview forms for teachers and classified support staff were combined into a single form. The forms were also restructured to provide additional space for recording responses.

In selecting interviewees for the various groups, I used the following procedures:

1. When completing the interview form for building administrators and counselors, I interviewed the building principal and/or the assistant principal most closely associated with the school's drug education program, along with as many of the counseling staff as were available. 
2. When interviewing teachers and support staff, I interviewed the two or three teachers most closely associated with the school's drug education program as well a selection of two or three teachers not necessarily associated with the school's drug education program, and at least one support staff such as a secretary or instructional aide.

3. When interviewing students who had not been diagnosed as being harmfully involved with alcohol and/or other drugs, I interviewed at least four students who were identified and selected by the building administration because of their availability.

4. When interviewing students who had been diagnosed as being harmfully involved with alcohol and/or other drugs, I interviewed at least four students who were identified and selected by the building administration because of their availability.

Data from these interviews may be a limitation to this study because the interviewees were not randomly selected. However, the data collected are nevertheless relevant to this descriptive multiple-case study and do provide the information required for the purposes of this study.

In preparing for the site visitations, I worked with a member of each school's administration to arrange an appropriate interview location and appointments with the various groups to be interviewed. A minimum of fifty minutes was allocated for the interviews with each of the 
various groups. The results of these site interviews are presented in Chapter IV of this study.

It is important to note that one of the school cases initially selected for a site visitation was later determined to be inappropriate for the study. The high school in question was initially identified as a successful school based on the data it reported in the written survey. Information obtained through the follow-up telephone interview with a school counselor substantiated the identification and referral rates that were originally reported. The follow-up telephone interview also led this researcher to believe that the school had documentary evidence to corroborate their stated identification and referral figures. When the visitation was conducted, however, the school did not have any documentary evidence that they could provide to substantiate their reported identification and referral rates. Also, interviews with the school principal, other school counselors, teachers, support staff and students indicated that the school actually identified very few students who were harmfully involved with alcohol and/or other drugs except for some students identified through school disciplinary proceedings. Given the lack of documentary evidence and the preponderance of other interview data indicating that few students were being identified as harmfully involved with alcohol and/or other drugs and referred to appropriate services, this researcher chose to eliminate this school 
from the study. Another school from the same enrollment classification was chosen as a replacement. The replacement school was identified in the initial written survey as one of the most successful schools in its enroll-ment classification, and it had also been identified as a successful school after having been a participant in the follow up telephone interview. No additional questioning was done of the replacement school prior to the site visitation. Evidence collected during the site visitation substantiated the fact that the school was successful in identifying and referring students harmfully involved with alcohol and/or other drugs. 
CHAPTER IV

PRESENTATION OF FINDINGS

During the months of January, February and March, 1989, site visitations of drug education intervention programs were conducted at twelve public high schools throughout the state of Washington. The twelve public high school substance abuse intervention programs that comprised this multiple-case study included eight programs that had been identified as being successful and four programs that had been identified as being unsuccessful as defined in chapter III. The twelve public high schools were separated into four groups according to student enrollment. The four enrollment classifications were:

1. Those schools with fewer than 500 students.

2. Those schools with 500 to 999 students.

3. Those schools with 1,000 to 1,499 students.

4. Those schools with more 1,500 students.

Two of the most successful and one of the least successful schools in each of the enrollment classifications were visited.

The identity of the twelve high school cases that make up this study will remain anonymous, as will the identity of the individual participants interviewed in each case. A 
school's ability to successfully identify and refer students who are harmfully involved with alcohol and/or other drugs is a potentially controversial issue, and the publication of an unsuccessful school's identity could result in adverse circumstances for that school and the individuals involved. Please see Appendix 3-A regarding additional demographic information about the twelve case high schools.

Multiple sources of evidence including documents (e.g. student handbooks, discipline policies, teacher observation sheets and referral forms); direct observations and interviews were collected and examined in order to answer the following study questions:

1. What kind of formal drug education instruction exists in the school at each grade level?

2. What kind of formal program does the school have for identifying students who are harmfully involved with alcohol and/or other drugs?

3. Which school staff members participate in the identification of students who are harmfully involved with alcohol and/or other drugs?

4. What kind of formal training do staff members receive to help them identify students who are harmfully involved with alcohol and/or other drugs?

5. Which school staff members are involved in referring students who are harmfully involved with alcohol and/or other drugs to an appropriate service? 
6. What kind of formal training do staff members receive to help them refer students who are harmfully involved with alcohol and/or other drugs to appropriate services?

7. Does the school have a student peer assistance program related to substance abuse among students?

8. Does the school have an established process for helping students obtain formal assessment relative to alcohol and/or other drug abuse and chemical dependency?

9. Does the school have an established re-entry program for students returning after having received counseling or treatment for alcohol and/or other drug abuse?

10. During the 1987-88 school year, did the school have a formal written policy regarding student alcohol and/or other drug abuse, and are students aware of it?

11. How does the school's drug education intervention program utilize outside agencies and organizations?

12. What are the most important aspects of your school's drug education intervention program?

13. How does central office administration and building administration support the school's drug education intervention program?

14. How does the community support the school's drug education intervention program?

15. How is the school's drug education intervention program managed (administered)? 
16. How can the school's drug education intervention program be improved?

This chapter consists of a descriptive cross-case summary and analysis of information collected from the twelve cases in regard to the established study questions. According to Yin (1987) this format is especially appropriate for multiple-case studies.

The fourth and last type of written product applies to multiple-case studies only. In this situation, there may be no separate chapters or sections devoted to the individual cases. Rather, the entire report may consist of the cross-case analysis, whether purely descriptive or also covering explanatory topics. In such a report, each chapter or section would be devoted to a separate cross-case issue, and the information from the individual cases would be dispersed throughout each chapter or section. (p. 129)

The descriptive cross-case summary and analysis groups the case observations of successful schools together and the case observations of unsuccessful schools together. This was done to facilitate the examination and comparison of the information collected.

Question 1. What kinds of formal drug education instruction programs exist in the school at each grade level?

Response Summary 1. All of the successful schools indicated that students received formal instruction in drug education in at least one class. The instruction typically took place during the required health class offered during the tenth or eleventh grade. Cases $4,5,7,10$ and 11 indicated that in addition to the required health course, 
students received information regarding drug education through various all school assemblies and other drug education activities.

with the unsuccessful schools, three schools indicated that they offered formal instruction in drug education during the required health course offered during the tenth or eleventh grade. Case 3 indicated that no formal instruction in drug education took place, even in the required health class.

Question 2. What kind of formal program does the school have for identifying students who are harmfully involved with alcohol and/or other drugs?

Response summary 2. Each of the successful schools indicated that they had a formal identification program. Case 2 indicated that they have a formal identification program that is operated by the principal and school counselor. Cases 1, 5, 8, 10 and 11 indicated that they operated a core team of teachers, counselors and administrators that work to identify students who are harmfully involved with alcohol and/or other drugs. Cases 4 and 7 indicated that they operated a student assistance program that also utilizes teachers, counselors and administrators in identifying students harmfully involved with alcohol and/or other drugs.

All of the unsuccessful schools indicated that they had no formal identification program for students who are harmfully involved with alcohol and/or other drugs. 
Question 3. Which school staff members participate in the identification of students who are harmfully involved with alcohol and/or other drugs?

Response Summary 3. All of the successful schools indicated that all staff members participate in the identification of students who are harmfully involved with alcohol and/or other drugs. Each of these schools indicated that this included classified staff, as well as the certified staff.

In the unsuccessful schools, cases 3 and 9 indicated that the building administrator would be responsible for identifying students who were harmfully involved with alcohol and/or other drugs. Cases 6 and 12 indicated that the building administrator would work with the school counselor in identifying these students.

Question 4. What kind of formal training do staff members receive to help them identify students who are harmfully involved with alcohol and/or other drugs?

Response summary 4. All of the successful schools indicated that they offer general awareness training to all staff in strategies for identifying students who are harmfully involved with alcohol and/or other drugs. This training includes information on how to use various check lists and key indicator forms that assist staff in recording student behavior that may indicate harmful involvement with alcohol and/or other drugs. 
With the unsuccessful schools, cases 3,6 and 12 indicated that there is no training made available to staff regarding the identification of students who were harmfully involved with alcohol and/or other drugs. Case 9 indicated that they began training staff in identification strategies in the latter part of the 1987-88 school year. This training was to prepare staff for a student assistance program they intended to implement during the 1988-89 school year.

Question 5. Which school staff members are involved in referring students who are harmfully involved with alcohol and/or other drugs to an appropriate service?

Response summary 5. All of the successful schools indicated that building administrators and counselors were involved with referring students. Cases 5, 10 and 11 also indicated that the core team assisted building administrators and counselors with referring students. Case 7 indicated that their full-time drug education intervention specialist worked with the building administrator and counselors in referring students.

In the unsuccessful schools, cases 3,6 and 12 indicated that the building administrator works with the school counselors in referring students who were harmfully involved with alcohol and/or other drugs. Case 9 indicated that it would be the counselors responsibility to refer students.

Question 6. What kind of formal training do staff members receive to help them refer students who are 
harmfully involved with alcohol and/or other drugs to appropriate services?

Response Summary 6. Each of the successful schools indicated that building administrators and counselors receive training in how to refer students who are harmfully involved with alcohol and/or other drugs to appropriate services. Each of the successful schools, except case 2, also indicated that their core team members and their student assistance team members also received this training. All of the unsuccessful schools indicated that no training was made available to staff in regard to referral strategies.

Question 7. Does the school have a student peer assistance program related to substance abuse among students?

Response summary 7. In the successful schools, cases $2,4,7,8,10$ and 11 indicated that they operated student peer assistance programs. Cases 1 and 5 indicated that they did not operate a student peer assistance program.

In the unsuccessful schools, cases 6 and 12 indicated that they did operate a student peer assistance program. Cases 3 and 9 indicated that they did not operate a student peer assistance program.

Guestion 8. Does the school have an established process for helping students obtain formal assessment relative to alcohol and/or other drug abuse and chemical dependency? 
Response summary 8. All of the successful schools indicated that they made formal assessments available to students. Each of these schools also indicated that the formal assessments were made available at no cost to the students.

All of the unsuccessful schools indicated that they did not make formal assessments available to their students.

Question 9. Does the school have an established reentry program for students returning after having received counseling or treatment for alcohol and/or other drug abuse?

Response Summary 9. Of the successful schools, cases 2 and 5 indicated that they did not operate an established re-entry program. Cases $1,4,7,10$ and 11 indicated that they operate a daily re-entry program, whereas case 8 indicated that they operate a weekly support group that deals with re-entry issues.

All of the unsuccessful schools indicated that they did not operate an established re-entry program.

question 10. During the 1987-88 school year, did the school have a formal written policy regarding student alcohol and/or other drug abuse, and are students aware of it?

Response summary 10. All of the successful schools indicated that they had formal written policies during the 1987-88 school year and that students were made aware of these policies through a published student handbook and various student orientations. All of these schools indicated 
that their written policies dealt with disciplinary issues as well as assistance issues for students who had been identified as being harmfully involved with alcohol and/or other drugs.

All of the unsuccessful schools also indicated that they had formal written policies during the 1987-88 school year and that students were made aware of these formal written policies through published student handbooks and various student orientations. Each of these schools indicated that their formal written policies dealt exclusively with disciplinary issues and did not address assistance issues regarding students who were identified as being harmfully involved with alcohol and/or other drugs.

Question 11. How does the school's drug education intervention program utilize outside agencies and organizations?

Response Summary 11. Of the successful schools, cases 2,5 and 11 indicated that they receive financial resources from outside agencies to help finance their drug education efforts. Case 4 indicated that they have no association with outside agencies. Cases 1, 7, 8 and 10 indicated that outside agencies, such as treatment centers, contribute staff training.

All of the unsuccessful schools indicated that they have no association with outside agencies regarding their drug education program. 
Question 12. What are the most important aspects of your school's drug education intervention program?

Response Summary 12. Most of the successful schools indicated that staff training and the availability of formal assessments were the most important aspects of their drug education intervention program. Cases 7 and 8 , who have full-time drug education specialists, indicated that those specialists were among the most important aspects of their program. Case 2 identified their formal written policies as one of the most important aspects of their program and case 4 indicated that the pervasive caring among administration and staff was one of the most important aspects of its program.

Among the unsuccessful schools, the most common response was that the school needed to make major improvements in its drug education program.

Question 13. How does central office administration and building administration support the school's drug education intervention program?

Response Summary 13. Each of the successful schools indicated that they enjoyed very strong support from central office administration and building administration. Most schools indicated that they especially appreciated the financial resources that were made available through central office administration, although case 11 criticized central office for not providing sufficient resources. Building 
administration was primarily credited for the leadership in creating and maintaining the drug education program.

of the unsuccessful schools, cases 3 and 6 indicated that central office administration and building administration recognized the need for an improved drug education program, but that the districts do not have the financial resources required to develop such a program. Case 9 indicated that administration was open about its nonsupport for a drug education program and case 12 indicated that administration was not willing to take a leadership role in developing a drug education program.

Question 14. How does the community support the school's drug education intervention program?

Response Summary 14. In the successful schools group, only case 2 indicated that there was significant community support and that this support was primarily the contribution of financial resources. Cases 1,4 and 8 indicated that there was no significant community support and cases 5,7 , 10 and 11 indicated that there was minimal community support and a definite need for this situation to be improved.

Each of the unsuccessful schools indicated that there was no significant community support for the school's drug education program. Case 9 did indicate that they felt a need to work to improve this situation.

Question 15. How is the school's drug education intervention program managed (administered)? 
Response Summary 15. Of the successful schools, cases 5, 7 and 8 indicated that a drug education specialist was responsible for managing the school's drug education program. Cases 1,10 and 11 indicated that a vice principal was responsible for managing the program, while cases 2 and 4 indicated that a vice principal worked with the counselor(s) in managing the school's drug education program.

of the unsuccessful schools, case 3 indicated that the principal was responsible for managing that school's drug education program. Case 6, 9 and 12 indicated that no one was responsible for managing the school's drug education program.

Question 16. How can the school's drug education intervention program be improved?

Response Summary 16. In the successful schools group, each of the cases indicated that additional staff training was necessary to improve the school's drug education program. Cases $1,2,4,5$ and 7 all indicated that more money was needed to improve the school's drug education program. Case 8 indicated that its recovery class needed to become a daily offering instead of a weekly offering. Case 2 indicated that they could improve their program by creating a re-entry class. Cases 7,10 and 11 indicated that they could improve their program by increasing parental awareness of the school's drug education program.

Each of the unsuccessful schools indicated that staff 
training was needed to improve the school's drug education program. Cases 3,6 and 12 indicated that financial resources were necessary to improve the school's drug education program. Case 9 indicated that administrative support would be needed if the school's drug education program was to be improved.

A comparison of several study question results from the twelve cases is presented in Table II entitled cross Analysis Grid. The table only illustrates whether or not a situation existed. A limitation of the table is that it does not illustrate the degree to which a situation exists, and the table only includes those situations that could be answered with a Yes or No response. Because of this limitation, questions 5,12 and 16 do not appear in the cross Analysis Grid. Nevertheless, the table is useful in comparing data between the successful schools and unsuccessful schools in several areas.

Question 5 asked which school staff members were involved in referring students who are harmfully involved with alcohol and/or other drugs to an appropriate service. This question could not be answered with a yes or no response so it does not appear in the Cross Analysis Grid. However, the information collected regarding this question does indicate that similarities exist among successful schools and unsuccessful schools. As noted on pages 64 and 65, four of the successful schools indicated that members of 
the core team and/or drug education intervention specialists worked with the building administrator and counselors in referring students. In each of the unsuccessful schools, however, only the building administrator and school counselors would work on referring students.

Question 12 asked students and staff to discuss the most important aspects of their school's drug education intervention program. Again, this question could not be answered with a yes or no response. The information collected, however, does indicate that similarities exist among successful schools and unsuccessful schools. As noted on page 68, most of the successful schools indicated that staff training and the availability of formal assessments were the most important aspects of their drug education intervention program. On the other hand, the most common response among the staff and student of the unsuccessful schools was that the school needed to make major improvements in its drug education program.

Question 16 asked how the school's drug education intervention program could be improved. This question could not be answered with a yes or no response, but their were similarities among successful schools and unsuccessful schools in the information that was collected. As discussed on pages 70 and 71 , each of the successful schools indicated that additional staff training was necessary to improve the school's drug education intervention program. Most of the 
successful schools also indicated that more money was needed and that their program could be improved by increasing parental awareness. Each of the unsuccessful schools also indicated that staff training and financial resources were necessary to improve the school's drug education program. 
TABLE II

CROSS ANALYSIS GRID

\begin{tabular}{|c|c|c|c|c|c|c|c|c|c|c|c|c|c|}
\hline & \multirow{2}{*}{\multicolumn{8}{|c|}{ SUCCESSFUL SCHOOLS }} & & & & \\
\hline & & & & & & & & & & \multicolumn{4}{|c|}{$\begin{array}{l}\text { UNSUCCESSFUL } \\
\text { SCHOOLS }\end{array}$} \\
\hline \multirow{2}{*}{$\begin{array}{l}\text { QUESTION } \\
\text { NUMBER }\end{array}$} & CASE NUMBER & 1 & 2 & 4 & 5 & 7 & 8 & 10 & 11 & 3 & 6 & 9 & 12 \\
\hline & QUESTION & & & & & & & & & & & & \\
\hline 1 & Formal instruction programs & $\mathrm{x}$ & $x$ & $\mathrm{x}$ & $\mathrm{x}$ & $\mathrm{x}$ & $\mathbf{x}$ & $\underline{x}$ & $\mathrm{x}$ & 0 & $\mathrm{x}$ & $\mathrm{x}$ & $x$ \\
\hline 2 & Formal identification program & $\mathrm{x}$ & $\underline{x}$ & $\mathrm{x}$ & $\mathrm{x}$ & $\mathrm{x}$ & $\mathrm{x}$ & $\mathrm{x}$ & $\mathrm{x}$ & 0 & 0 & 0 & 0 \\
\hline 3 & Staff members identify students & $\mathrm{x}$ & $\mathrm{x}$ & $\mathrm{x}$ & $\mathrm{x}$ & $\mathrm{x}$ & $\mathrm{x}$ & $\mathrm{x}$ & $\mathrm{x}$ & 0 & 0 & 0 & 0 \\
\hline 4 & $\begin{array}{c}\text { Staff training in } \\
\text { identification }\end{array}$ & $\mathbf{X}$ & $\mathbf{x}$ & $\mathbf{x}$ & $\mathbf{x}$ & $\mathbf{x}$ & $\mathbf{x}$ & $\mathbf{x}$ & $\mathbf{x}$ & 0 & 0 & 0 & 0 \\
\hline 6 & staff training in referral & $\mathrm{x}$ & $\mathbf{x}$ & $\mathrm{x}$ & $\mathrm{X}$ & $\mathrm{x}$ & $x$ & $\mathrm{x}$ & $\mathrm{x}$ & 0 & 0 & 0 & 0 \\
\hline 7 & $\begin{array}{c}\text { student peer assistance } \\
\text { programs }\end{array}$ & 0 & $\mathrm{X}$ & $\mathrm{x}$ & 0 & $\mathrm{x}$ & $\mathbf{x}$ & $\mathbf{x}$ & $\mathrm{x}$ & 0 & $\mathrm{x}$ & 0 & $\mathrm{x}$ \\
\hline 8 & Formal assessments available & $\mathrm{x}$ & $\mathrm{x}$ & $\underline{x}$ & $x$ & $\mathrm{x}$ & $\mathbf{x}$ & $\mathbf{x}$ & $x$ & 0 & 0 & 0 & 0 \\
\hline 9 & Established reentry programs & $x$ & 0 & $\underline{x}$ & 0 & $x$ & $\mathbf{x}$ & $\underline{x}$ & $\underline{x}$ & 0 & 0 & 0 & 0 \\
\hline 10 & Formal written policies & $\mathrm{x}$ & $\mathrm{x}$ & $\underline{x}$ & $\mathrm{x}$ & $\mathrm{x}$ & $x$ & $\underline{x}$ & $\underline{x}$ & $\mathrm{x}$ & $\mathrm{x}$ & $x$ & $\mathbf{x}$ \\
\hline 11 & Outside agencies & $\mathrm{x}$ & $\mathrm{x}$ & o & $\mathrm{X}$ & $\mathrm{x}$ & $\mathrm{x}$ & $\mathrm{x}$ & $\mathrm{x}$ & 0 & 은 & 0 & 은 \\
\hline 13 & Administrative support & $\mathbf{x}$ & $\mathbf{x}$ & $\mathrm{x}$ & $\mathrm{x}$ & $x$ & $\underline{x}$ & $\underline{x}$ & $\mathrm{x}$ & 0 & 은 & 0 & 0 \\
\hline 14 & Community support & 0 & $x$ & 0 & $\mathbf{x}$ & $\mathrm{x}$ & 0 & 0 & 0 & 0 & 0 & 0 & 0 \\
\hline 15 & Program management & $\mathrm{x}$ & $x$ & $\mathrm{x}$ & $x$ & $\mathrm{x}$ & $x$ & $\mathrm{x}$ & $\underline{x}$ & $\mathrm{x}$ & $\underline{0}$ & 0 & $\underline{0}$ \\
\hline
\end{tabular}

* Cases are grouped as successful and unsuccessful in order to facilitate data interpretation and comparison. 
CHAPTER V

DISCUSSION, CONCLUSIONS AND RECOMMENDATIONS

\section{DISCUSSION}

A study of the identification and referral components of substance abuse intervention programs in washington State's public high schools was conducted to accomplish the following purposes:

Purpose I. The first purpose of this study was to identify and describe the characteristics of public high school substance abuse intervention programs that are successful in identifying students harmfully involved with alcohol and/or other drugs and referring these students to appropriate services.

Purpose II. The second purpose of this study was to identify and describe the characteristics of public high school substance abuse intervention programs that are unsuccessful in identifying students harmfully involved with alcohol and/or other drugs and referring these students to appropriate services.

Purpose III. The third purpose of this study was to determine the characteristics of a public high school substance abuse intervention program that enable it to be successful in identifying students harmfully involved with 
alcohol and/or other drugs and referring them to appropriate services by comparing and contrasting the characteristics of successful and unsuccessful public high school substance abuse intervention programs.

During the months of January, February and March, 1989, site visitations of twelve washington state public high school substance abuse intervention programs were conducted. Eight of these site visitations were conducted with programs that had been defined as successful according to the criteria established in Chapter III. Four of the site visitations were conducted with schools identified as being relatively unsuccessful programs as defined in Chapter III.

Multiple sources of evidence were used to gather information regarding the established study questions. This evidence included staff interviews, student interviews, the collection of various documents and interview observations. All of this evidence has been organized into a comprehensive data base that includes a case report for each of the twelve cases visited (see Appendix 3 - Case Reports).

A descriptive cross-case summary and analysis of this information were presented in Chapter IV. The descriptive cross-case summary and analysis identifies the common characteristics that exist among the eight successful high school intervention programs as defined in chapter III. The cross-case summary and analysis also identifies the 
common characteristics among the four unsuccessful high school intervention programs as defined in chapter III. Purposes I and II were partially fulfilled by the descriptive cross-case summary and analysis in chapter IV. The conclusions and recommendations presented in the remainder of this chapter will serve to complete Purposes I and II, as well as fully address Purpose III.

\section{CONCLUSIONS}

The conclusions of this study are presented using the propositions established in chapter III as the framework for discussion.

\section{Proposition I:}

Successful public high school substance abuse intervention programs share certain common characteristics that enable them to successfully identify students who are harmfully involved with alcohol and/or other drugs and refer these students to appropriate services.

Evidence collected during the site visitations for the twelve schools identify a set of program characteristics that successful public high school substance abuse intervention programs have in common. These common characteristics are illustrated in Table II (page 74).

The results of this study identify seven characteristics that affect the success of a school's substance abuse intervention program as defined in chapter III. The 
following characteristics are shared by successful public high school substance abuse intervention programs, and according to this study enable these intervention programs to successfully identify students who are harmfully involved with alcohol and/or other drugs and refer these students to appropriate services:

1. Formal Identification Program. Each of the successful schools indicated that they have established a formal identification program that includes procedures and specific staff responsibilities. Formal identification programs also include an individual or group of individuals who are specifically assigned the task of handling the individual cases of students who are identified as possibly being harmfully involved with alcohol and/or other drugs. Responsibilities for handling the case would typically consist of investigating the student's background (attendance record, discipline record, grades, friends and family situation). In a formal identification program, all staff would know what individual or group of individuals was responsible for this task, and all staff would also be aware of how to report information to this individual or group of individuals.

2. Staff Involvement in Identifying students. All of the successful schools indicated that all staff members participate in the identification of students who are harmfully involved with alcohol and/or other drugs. For each school, all staff meant that classified employees such as custodians 
and secretaries participated in the identification of students who are harmfully involved with alcohol and/or other drugs just as teachers, counselors and administrators. Staff involvement means that all staff have been trained in skills for identifying students who are harmfully involved with alcohol and/or other drugs, and that all staff have been encouraged and empowered to participate in this process.

3. Staff Training in Identification. Each of the successful schools indicated that training was made available for all staff in how to identify students who are harmfully involved with alcohol and/or other drugs. Training in identification skills was usually tied to using an established referral document that contained various student behaviors that relate to a student being harmfully affected by their own use or a family member's use of alcohol and/or other drugs. schools indicated that a general awareness training in identification skills for staff can be accomplished in one or two hours, but most schools indicated that most of their staff had received at least one day of training in substance abuse issues with identification skills being incorporated in that training.

4. Referral Training. Each of the successful schools indicated that members of their staff had received specific training in how to refer students who are harmfully involved with alcohol and/or other drugs to appropriate services. 
Referral training also assisted staff in identifying the various kinds of resources that may need to be utilized when seeking assistance for students who are harmfully involved with alcohol and/or other drugs. Schools indicated that referral training should prepare staff for working with treatment agencies, various counseling services, law enforcement and government agencies that are responsible for child abuse issues.

5. Formal Assessments. All of the successful schools indicated that they made formal assessments available to their students at no cost. Formal assessments are clinical evaluations conducted by qualified individuals who are able to determine the extent of a student's involvement regarding alcohol and/or other drugs. Formal assessments also determine whether or not a student is being adversely affected by a family member's abuse of alcohol and/or other drugs. The availability of formal assessments contributes to the success of a high school's substance abuse intervention program. All schools indicated that is was essential that assessment services be made available at no cost to their students so that no one is denied the service. They also indicated that it is essential that these services be made available on the school premises during regular school hours.

6. Established Re-entry Programs. Six out of the eight successful schools indicated that they operate an 
established re-entry program, and five of the schools indicated that they operated a daily recovery class. Reentry programs can either be regular class offerings or special support group activities that assist students in maintaining their sobriety and adjusting to their new life style. Re-entry programs also provide students with regular access to counseling services in support of their recovery efforts. Most students interviewed who were in the re-entry programs indicated that they probably wouldn't be in school if the re-entry program didn't exist.

7. Administrative support. Staff from each of the successful schools indicated that they enjoyed strong administrative support from both the central office and school level. Administrative support was in the form of leadership and resources. Building administration was identified as being critical to the establishment and maintenance of a successful substance abuse intervention program. It is this researcher's opinion that school level administrative support for the substance abuse intervention program is closely associated with the installation of the other six characteristics described in this section that affect the success of a school's substance abuse intervention program.

\section{Proposition II:}

Unsuccessful public high school substance abuse intervention programs lack certain common characteristics that prevent them from being able to successfully identify 
students who are harmfully involved with alcohol and/or other drugs and refer these students to appropriate services.

Evidence collected during the site visitations for the twelve schools identify a set of program characteristics that unsuccessful public high school substance abuse intervention programs have in common. These characteristics common among unsuccessful intervention programs are illustrated in Table II as were the characteristics common among successful intervention programs. An examination of Table II shows that some of the characteristics that are common among unsuccessful schools are also found among the successful schools. More compelling to this researcher are the results of this study that indicate that unsuccessful public high school substance abuse intervention programs all lack certain common characteristics that exist in all successful schools, and that the absence of these characteristics prevent the unsuccessful schools from being able to successfulIy identify students who are harmfully involved with alcohol and/or other drugs and refer these students to appropriate services. According to this study, the unsuccessful intervention programs lack the same seven characteristics that were identified in Proposition $I$, and it is the absence of these characteristics that makes them unsuccessful.

1. Lack of Formal Identification Program. Each of the unsuccessful schools indicated that they did not have a 
formal identification program, such that none of the unsuccessful schools had procedures for identifying students nor did they have individuals or a group of individuals responsible for handling students identified as possibly being harmfully involved with alcohol and/or other drugs except for traditional counseling services.

2. Lack of staff Involvement in Identifying students. All of the unsuccessful schools indicated that only the school administrator(s) and/or school counselor(s) had any association with identifying students who were harmfully involved with alcohol and/or other drugs. None of the unsuccessful schools indicated that any efforts were made to identify students harmfully involved with alcohol and/or other drugs beyond those students that were identified through traditional disciplinary procedures or routine counseling services.

3. Lack of Staff Training in Identification. All of the unsuccessful schools indicated that no staff training had been made available to any staff regarding skills in identifying students who are harmfully involved with alcohol and/or other drugs.

4. Lack of Referral Training. Each of the unsuccessful schools indicated that no special training in referral skills had been made available to any staff including counselors and administrators.

5. Lack of Access to Formal Assessments. Each of the unsuccessful schools indicated that formal assessments were 
not made available to their students through the school system. Some administrators and counselors indicated that students could obtain formal assessments through local treatment facilities, but the schools were not directly involved in arranging these.

6. Lack of Established Re-entry Programs. Each of the unsuccessful schools indicated that they had no existing re-entry program, and each of the unsuccessful schools also indicated that they were unsure as to how many students in their school had ever received treatment for chemical dependency.

7. Lack of Administrative Support. Although building administration in the unsuccessful schools indicated that central office and school level administrative support existed for substance abuse programs, they acknowledged that little was being done because they lacked sufficient financial resources. Teachers and support staff on the other hand, indicated that there was very little school level or central office administrative support for substance abuse intervention programs. Staff indicated that administration would have to provide leadership in this area before an effective substance abuse program could be established.

\section{Proposition III:}

Staff who operate and manage successful public high school substance abuse intervention programs share common ideas and recommendations regarding what leads to the 
improvement and success of a high school substance abuse intervention program.

While interviewing administrators, counselors, teachers, classified staff and drug education specialists from the various successful school programs, it became clear that they all shared some very specific ideas and recommendations about what makes a substance abuse intervention program successful and how even successful programs can continue to be improved. The following observations are those most commonly expressed by the staff who operate and manage successful public high school substance abuse intervention programs as defined in Chapter III:

1. Administrative support. School administrators and other staff alike recognize the importance of central office support for a school's drug education intervention program. Central office administrative support is critical in that such support influences the school level administration's support for the school's substance abuse intervention program. Also, support from the central office administration was seen as very important in order to receive the financial resources that are required to operate a successful program. Staff did observe, however, that school level administration support was even more important than central office support for a successful substance abuse intervention program. School level administrative support was critical for the program's implementation and day to day operation. staff agreed that without school level administration 
support there could not be a successful substance abuse intervention program in the school.

2. Staff Training. All staff agreed that general awareness training for all staff was important to the success of an intervention program. Also, those individuals responsible for administering the program said they required additional and more specific training. Additional training that was identified as being valuable include identification strategies, referral strategies, support groups, assessment skills and group process skills for managing a core team or student assistance team.

3. Assessment Services. All successful schools indicated that access to formal assessment services was extremely important to the success of the school's substance abuse intervention program. Formal assessment services provided the necessary link to treatment and other appropriate services for those students who could not be adequately served by existing school services. Because formal assessment services were available, schools were able to direct students to an appropriate service when they had been identified as being harmfully involved with alcohol and/or other drugs. Staff felt that if formal assessment services were not available, staff would be less likely to actively seek out students who are harmfully involved with alcohol and/or other drugs because once identified, the schools wouldn't know what to do with the students. 
4. Dedicated Staff Time. All staff recognized the need for schools to allow for adequate staff time in managing and operating a successful drug education intervention program. Typically, dedicated staff time was accomplished by hiring a drug education specialist for this role or contracting privately for these services, or releasing a teacher, counselor or administrator from other responsibilities for a portion of the day so that they can manage the program. Staff in each of the successful schools indicated that without specifically dedicated staff time to manage the program, the operation of the program would eventually be set aside for other priorities and the program would cease to be as successful. Each of the schools without a fulltime drug education specialist indicated that they needed more dedicated staff time to operate their existing program effectively.

5. Financial Resources. All staff indicated that financial resources were critical to the success of a school's drug education intervention program. Financial resources would make possible the staff training, staff time, curriculum materials and assessment services that are all so important to building a successful drug education intervention program. Each of the successful schools indicated that additional financial resources would enable them to further improve their programs by providing additional staff time and/or additional staff training 
and/or other related activities such as awareness training for parents.

\section{RECOMMENDATIONS FOR THE APPLICATION OF CONCLUSIONS BY PRACTITIONERS}

Educators and government officials alike must be careful not to overgeneralize the conclusions presented in this study. This study of substance abuse intervention programs in Washington State's public high schools was based on the assumption that all secondary schools in Washington State have similar percentages of their respective student bodies who are harmfully involved with alcohol and/or other drugs. With this assumption, this researcher was able to establish an operational definition for identifying successful high school substance abuse intervention programs as presented in Chapter III.

This multiple-case study compares and contrasts the common characteristics of eight successful public high school substance abuse intervention programs and four unsuccessful public high school substance abuse intervention programs as defined in chapter III. It was conducted among high school substance abuse intervention programs within Washington state only, so possible cultural and socioeconomic conditions may exist that warrant further inquiry before generalizing to a nationwide population.

The discussion, conclusions and recommendations presented in this study are descriptive and explanatory in 
that various how and why questions are answered. Objective survey data, documentary evidence, interview responses and researcher observations were all taken into consideration as this researcher developed the conclusions and recommendations. It is the opinion of this researcher that this study has identified a set of descriptive guidelines that can be used by educators as they work to establish or improve successful substance abuse intervention programs in their schools. This researcher recommends that schools looking to establish or improve their high school substance abuse intervention programs consider the following guidelines:

1. Administrative support at the central office level and the building level must be enthusiastic and overt. Schools are dependent upon administration to provide the motivation, leadership and resources required of a successful drug education intervention program. In order to establish such administrative support, central office administrators and school level administrators alike should all complete comprehensive awareness training regarding substance abuse issues and effective intervention programs.

2. Schools must provide staff time for program management. Schools cannot rely on volunteers or staff who will assume the responsibilities for the program's operation over and above their other full-time job responsibilities. Although volunteer time and after school time can temporarily be used to operate a program, the program's continued 
success is dependent on someone's ability to attend to program management needs on a regular basis. Even the most zealous volunteers will eventually tire of their program responsibilities if these responsibilities are added on to their other responsibilities. Also, if a conflict arises, their regular job responsibilities will take precedence over their substance abuse program responsibilities, and the substance abuse program will suffer.

3. Formal assessments for determining the specific needs of a student relative to substance abuse and related issues is critical to the success of a drug education intervention program. Formal assessments serve three major purposes: (a) they motivate staff to initially identify kids who may be harmfully involved with alcohol and/or other drugs because a mechanism for additional student services exists, (b) the school is able to obtain clinical, objective information about a student's condition relative to substance abuse and related issues because of the formal assessment services and (c) formal assessment services provide linkages to additional services that students may require depending upon the severity of their problems. Such services may include group therapy, family counseling and treatment for chemical dependency. It must be emphasized that these assessment services need to be made available to all students at no cost, and that these services need to be available at the school site. 
4. Staff training in substance abuse intervention issues is absolutely essential. General awareness training in substance abuse issues and specific identification strategies for all staff is very important to the success of an intervention program because the training will serve to make staff more sensitive to the characteristics and problems of students harmfully affected by alcohol and/or other drugs, as well as cause staff to revisit their own use of alcohol and/or other drugs. In addition, individuals responsible for linking students to school services and formal assessments need more specific training in the areas of identification skills, referral skills, counseling skills and group process skills. Training programs need to be based on effective staff development research in that the training won't be of any benefit if it is not delivered in an effective fashion.

5. All staff members need to be involved in the formal identification processes for students who may be harmfully involved with alcohol and/or other drugs. The school-wide identification program that utilizes bus drivers, secretaries, custodians, teacher aides, teachers, counselors and building administrators is going to do a better job of identifying students who may otherwise slip through the cracks of a less comprehensive identification process. To be appropriately involved in the identification aspects of a school's program, all staff should receive 
general awareness training in substance abuse issues as well as training in specific identification strategies.

RECOMMENDATIONS AND IMPLICATIONS FOR FURTHER RESEARCH

The preceding conclusions and recommendations regarding the development and/or improvement of a successful high school substance abuse intervention program were developed from a descriptive multiple-case study using only high school programs in Washington state. This researcher recommends that an additional multiple-case study examining schools in other states be done to verify or contradict the findings of this study. Similar results from a replication of this multiple-case study would serve to strengthen the external validity and generalizability of this study.

A second recommendation for further research would be to examine more specifically the effects of formal student instruction related to drug education and its effects on the success of an intervention program. This study was unable to discern any relationship between formal student instruction and the success of an intervention program in identifying and referring students who are harmfully involved with alcohol and/or other drugs to appropriate services. Our educational system allocates substantial resources to formal instructional programs and the effects of these programs warrant additional analysis. It is important to note that while this researcher talked with students in the twelve 
different high schools, students noted that the greatest peer pressure to use alcohol and/or other drugs occurs when students first reach high school (ninth or tenth grades depending on the high school's configuration). Most schools, however, offer no formal substance abuse instruction until health class which is usually taken in the second year of high school.

A third recommendation for further research would be a study that examined the actual effectiveness of the intervention services that are provided for students after they have been identified as being harmfully involved with alcohol and/or other drugs and referred to those services. An intervention program's ability to identify students who are harmfully involved with alcohol and/or other drugs and refer them to services would be a futile effort if those services to which students are referred cannot effectively address the problems of that student. Intervention services to be examined would include support groups, family counseling, out-patient treatment for chemical dependency and in-patient treatment for chemical dependency.

A final recommendation for further research would be a study that identified intervention programs that lack the successful identification and referral components defined by this study. Such a study would add those missing components and observe whether or not the addition of those components resulted in the intervention program being more successful 
in its identification and referral efforts. The seven characteristics identified in this study that affect a substance abuse intervention program's ability to successfully identify students who are harmfully involved with alcohol and/or other drugs and refer these students to appropriate services include:

1. Formal identification programs.

2. All staff members identifying students.

3. All staff members trained in identification.

4. Staff trained in referring students.

5. Formal assessments available.

6. Established re-entry programs.

7. Administrative support. 
SOURCES CONSULTED

Alibrandi, T. (1985). Young Alcoholics. Minneapolis, MN: Comp Care Publications.

Alcohol, Drug Abuse and Mental Health Administration (1985, July). Secretary's Task Force: Youth and Suicide. Alcohol, Drug Abuse, and Mental Health News, 11(7), p 316. Rockville, MD: U. S. Department of Health and Human Services.

Anderson, G. L. (1987). When Chemicals come to School. Greenfield, WI: Community Recovery Press.

Anonymous, (1988, March). To Help Substance Abusers, We Must First Help Ourselves. Educational Leadership, pp. 21-26.

Bell, R. (1988). Using the concept of Risk to Plan Drug Use Intervention Programs. Journal of Drug Education, 18(2), 135-142.

Bennett, W. J. (1986) - What Works: Schools without Drugs. Washington, D.C.: U.S. Department of Education.

Birch, J. W. \& Mauch, J. E. (1983). Guide to the successful Thesis and Dissertation. New York: Marcel Dekker, Inc.

Blotner, R. \& Lilly, L. (1986). S.P.E.C.D.A. A Comprehensive Approach to the Delivery of substance Abuse Prevention Services in the New York City School system. Journal of Drug Education, 16(1), 83-90.

Blum, R. H., Blum, E and Garfield, E. (1976) . Drug Education: Results and Recommendations. Massachusetts: Lexingtor Books.

Borg, W. R. \& Gall, M. D. (1983). Educational Research: An Introduction. New York: Longman.

Botvin, G. J. (1986, November). Substance Abuse Prevention Research: Recent Developments and Future Directions. Journal of School Health, 56(9), 369-374. 
Brower, K. J. \& Anglin, M. D. (1987). Adolescent Cocaine Use: Epidemiology, Risk Factors and Prevention. Journal of Drug Education, 17(2), 163-181.

Bukoski, w. J. (1979). Drug Abuse Prevention Evaluation: A Meta-Evaluation Process. Presented at American Pubic Health Association Annual Meeting.

Bukoski, W. J., Griswold-Ezekoye, S. \& Kumpfer, K. I. (1985). Childhood and Chemical Abuse: Prevention and Intervention. New York: The Haworth Press.

California Commission on the Prevention of Drug and Alcohol Abuse (1986). Statewide survey of Student Drug Abuse. Sacramento, CA: California Department of Justice.

Carlson, P. L. \& Schaefer, W. (1986, February) . What Educators Can Do: Identifying, Assisting the Disturbed Adolescent. National Association of Secondary School Principal's Bulletin, pp. 6-9.

Davis, B. C. \& Hollander, M. J. (1983). Trends in Adolescent Alcohol and Drug Use in Vancouver. British Columbia: Ministry of Health.

Dillman, D. A. (1978). Mail and Telephone surveys: The Total Design Method. New York: John Wiley \& Sons, Inc.

Donovan, J. E. \& Jessor, R. (1983). Problem Drinking and the Dimension of Involvement with Drugs: A Guttman Scalogram Analysis of Adolescent Drug Use. American

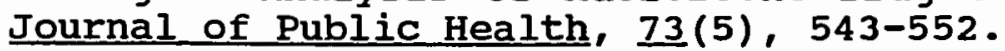

Donovan, J. E., Jessor, R. \& Jessor, L. (1983). Problem Drinking in Adolescence and Adulthood. Journal of Studies on Alcohol, 44, 109-137.

Downing, N. E. \& Walker, M. E. (1987, April). A Psychoeducational Group For Adult Children of Alcoholics. Journal of Counseling and Development, 63.

Drug Traffic and Abuse in Schools (1986). National School Safety Center Resource Paper. Washington, D.C.: Office of Juvenile Justice and Delinquent Prevention (ERIC Document Reproduction Service No. ED 271666).

Duryea, E. J. \& Okwumabua, J. O. (1988) - Effects of a Preventative Alcohol Education Program After Three Years. Journal of Drug Education, 18(1), 23-32. 
Eddy, J. (1973). The Teachers and the Drug Scene. Bloomington, IN: Phi Delta Kappa.

Ellickson, P. L. (1984). Designing an Effective Prevention Program: Principles Underlying the Rand Smoking and Drug Prevention Experiment. California: Rand Corporation Publication, No. P-7068.

Ellickson, P. L. (1984). Project Alert: A Smoking and Drug Prevention Experiment, First Year Progress Report. California: Rand Corporation Publication, No. P-7068.

Ellickson, P. L., Kaham, J. P., Polich, J. M. \& Reuter, P. (1984). Strategies for Controliing Adolescent Drug Use. California: The Rand Corporation.

Ellickson, P. L. \& Robyn, A. E. (1987). Toward More Effective Drug Prevention Programs. California: Rand Corporation Publication, No. N-2666-CHF.

Evans, R. I. (1981). Social Modeling Films to Deter Smoking in Adolescents: Results of a Three Year Field Investigation. Journal of Applied Psychology, 66, 339-414.

Farrar, E. \& Hampel, R. L. (1987, December). Social Services in American High Schools. Phi Delta Kappan, pp. 297-303.

Fields, G. M. (1988, March). You Cannot Delegate Leadership. Educational Leadership, pp. 33-35.

Fitzpatrick, G. (1983). Evaluation of an Alcohol Education Program for Teachers: A Case Study. Research Paper. (ERIC Document Reproduction Service No. ED 249191).

Flood, D. H. \& Morehouse E. R. (1986, February). The Principal's Role in Preventing and Reducing student Substance Abuse. National Association of Secondary School Principal's Bulletin, pp. 10-15.

Grady, K., Gersick, K. E. \& Snow, D. L. (1986). The Emergence of Adolescent Substance Use. Journal of Drug Education, 16(3), 203-220.

Gluckman, I. B. \& Zirkel, P. A. (1987, March). Drug Testing in Public Schools, National Association of Secondary School Principal's Bulletin, pp. 138-141.

Goodstadt, M. S. (1978). Alcohol and Drug Education: Models and outcomes. Health Education Monographs, $\underline{6}$, 263-279. 
Goodstadt, M. S. (1980). Drug Education - A Turn on or A Turn off? Journal of Drug Education, 10(2), 89-99.

Goodstadt, M. S. (1986, September). School-Based Drug Education in North America: What is Wrong? What can be Done? Journal of School Health, $\underline{56}(7), 278-281$.

Goodstadt, M. S. (1987). Prevention strategies for Drug Abuse. Issues in Science and Technology, pp. 28-35.

Goodstadt, M. S. \& Sheppard, M. D. (1983). Three Approaches to Alcohol Education. Journal of Studies on Alcohol, $\underline{44}(2), 362-380$.

Goodstadt, M. S., Sheppard, M. D. \& Chan, G. C. (1982). Relationships between Drug Education and Drug Use. Journal of Drug Issues, $3,431-442$.

Gorman, D. R., Marty, P. J. \& Werch, C. E. (1987) . Relationship Between Alcohol Consumption and Alcohol Problems in Young Adults. Journal of Drug Education, 17(3), 261-276.

Griffin, T. \& Svendsen, R. (1986). The Student Assistance Program, How it Works. Minneapolis, MN: Hazelden Foundation.

Hansen, W. B., Graham, J. W., Wolkenstein, B. H., Lundy, B. Z., Pearson, J., Flay, B. R. \& Johnson, C. A. (1988). Differential Impact of Three Alcohol Prevention Curricula on Hypothesized Mediating Variables. Journal of Drug Education, 18(2), 143-154.

Hanson, D. J. (1980) - Drug Education: Does it Work? in F. R. Scarpitti and S. K. Datesman (eds.) Drugs and the Youth Culture. Beverly Hills, CA: Sage Publications.

Hawley, R. A. (1987, May). School Children and Drugs: The Fancy that has not Passed, phi Delta Kappan: Kappan Special Report. Bloomington, IN: Phi Delta Kappa.

Hazelden Health Promotion (1986, March). Yakima Public Schools student Survey. Minneapolis, MN: Hazelden Foundation.

Herberg, T. (1987, March). Fourteen Steps to Developing a Comprehensive Drug Education Program. A National Conference Paper: National Association for supervision and Curriculum Development, unpublished.

Hopkins, J. D. (1986). Seattle Public school student survey. Seattle, WA: University of Washington. 
Horton, L. (1988, March). The Education of Most Worth: Preventing Drug and Alcohol Abuse. Educational Leadership, pp. 4-14.

Jessor, R. (1982). Problem Behavior Developmental Transition in Adolescence. Journal on School Health, 52(5), 295-300.

Jessor, R. \& Jessor, S. (1977). Problem Behavior and Psychosocial Development: A Longitudinal Study of Youth. New York: Academic Press.

Johnson, C. A. (1983). The Promise of Social Psychologically Based Programs for Primary Prevention of Drug Abuse. Health Behavior Research Institute Publication, University of Southern California at Los Angeles.

Johnson, C. A. (1986, November). Objectives of Community Programs to Prevent Drug Abuse. Journal of School Health, 56(9) November, 364-368.

Johnson, C. A. , Hansen, W. B., Collins, L. M. \& Graham, J. W. (1986). High School Smoking Prevention: Results of a Three-year Longitudinal study. Journal of Behavioral Medicine, $9(5)$.

Johnston, L. D., Bachman, J. G. \& O'Malley, P. M. (1979). Drugs and the Class of 178: Behaviors, Attitudes, and Recent National Trends. Rockville, MD: National Institute on Drug Abuse.

Johnston, I. D., Bachman, J. G. \& O'Malley, P. M. (1982). Student Drug Use, Attitudes, and Beliefs. Rockville, MD: National Institute on Drug Abuse.

Johnston, L. D., O'Malley, P. M. \& Bachman, J. G. (1984). Highlights from Drugs and American High School Students 1975-83. Rockville, MD: National Institute on Drug Abuse.

Johnston, L. D., O'Malley, P. M. \& Bachman, J. G. (1985). Use of Licit and Illicit Drugs of American High School Students: 1975-1984. Rockville, MD: National Institute on Drug Abuse.

Johnston, L. D., O'Malley, P. M. \& Bachman, J. G. (1986). Drug Use Among American High School students, College Students and other Young Adults: National Trends Through 1985. National Institute on Drug Abuse Research Monograph, DHHS Publication No. (ADM) 86-1450. Washington, D.C.: U. S. Government Printing office. 
Kandel, D. \& Logan J. (1984). Patterns of Drug Use from Adolescence to Young Adulthood: Periods of Risk for Initiation, Continued use and Discontinuation. American Journal of Public Health, 74(7).

Kinder, B. N., Pape, N. E. \& Walfish, S. (1980). Drug and Alcohol Evaluation Program: A Review of Outcome studies. The International Journal of the Addictions, 15(7), 1035-1054.

Lohrmann, D. K. \& Fors, S. W. (1986). Can School-Based Educational Programs Really be Expected to Solve the Adolescent Drug Abuse Problem? Journal of Drug Education, 16(4), 327-337.

McCurdy, J. (1986). The Drug Free School: what School Executives Can Do. Education USA Executive Summary, \#1. Virginia: National school Public Relations Association.

Miles, M. B. \& Huberman, A. M. (1984). Qualitative Data Analysis: A Sourcebook of New Methods. Beverly Hills, CA: Sage Publications, Inc.

Milgram, G. G. (1987). Alcohol and Drug Education Programs. Journal of Drug Education, 17(1), 43-59.

Mitchell, H. H. (1968). Alcohol and Traffic Accidents. California: Rand corporation Publication, No. RM5635-DOT.

Moskowitz, J. M. \& Others (1981). Psychometric Properties of the 'Drug and Alcohol Survey'. National Institute on Drug Abuse.

National Clearinghouse For Alcohol and Drug Information (1987, January). Alcohol Topics: Fact Sheet, Alcohol and Youth. Rockville, MD: National Clearinghouse for Alcohol and Drug Information Publication.

National Institute on Drug Abuse (1982). Adolescence: Intervention Strategies. Reference Book.

National Institute on Drug Abuse (1986). Data From the Drug Abuse Warning Network: Annual Data, 1985. Statistical Series $I$, \#5, DHHS Publication, No (ADM) 86-1469. Washington, D. C.: U. S. Government Printing office.

National Institute on Drug Abuse (1987). National Trends in Drug Use and Related Factors Among American High School students and Young Adults, (1987)-(1986). Washington, D.C.: U. S. Government Printing office. 
National Institute on Drug Abuse (1988). High School Senior Drug Usage: 1975-1987, Monitoring the Future Study. Washington, D.C.: U. S. Government Printing Office.

Newcomb, M. D. \& Bentler, P. M. (1986). Frequency and Sequence of Drug Use: A Longitudinal Study from Early Adolescence to Young Adulthood. Journal of Drug Education, 16(2), 101-120.

Newcomb, M. D., Maddahian, E. \& Bentler, P. M. (1986, May). Risk Factors for Drug Use Among Adolescents: Concurrent and Longitudinal Analyses. American Journal of Public Health, 76, 525-531.

Office for Substance Abuse Prevention (1987). Alcohol, Drug Abuse and Mental Health Administration. Helping Communities to Help Themselves, Twenty Exemplary Projects. Washington, D.C.: U. S. Government Printing office.

Office for Substance Abuse Prevention (1987). The Fact Is: You Can Prevent Alcohol and other Drug problems Among Elementary School Children. Rockville, MD: National Institute on Drug Abuse.

Oregon Department of Human Resources (1986). The Prevalence of Drug Use Among oregon Students. Salem, OR: Author

Perry, C., Telch, M., Killen, J., Burke, A. \& Maccoby, N. (1983). High School Smoking prevention: The Relative Efficiency of Varied Treatments and Instructors. Adolescence, $18(71)$.

Pisano, S. \& Rooney, J. (1988). Children's Changing Attitudes Regarding Alcohol: A Cross-Sectional study. Journal of Drug Education, 18(1), 1-11.

Pollin, w. (1987, Winter). Drug Abuse, U.S.A.: How Serious? How Soluble? Issues in Science and Technology, pp. 20-27.

Reagan, N. (1986, October). How We Can Make a Difference: About Drug Abuse and Young People. National Association of Secondary school Principal's Bulletin, pp. 39-43.

Rickett, M. \& Sheppard, M. A. (1988). Decision-Making and Young People. Journal of Drug Education, 18(2), 109114. 
Rosiak, J. (1987, March). Effective Learning Demands DrugFree Schools, National Association of Secondary School Principal's Bulletin, pp. 128-133.

Schaps, E., DiBartolo, R., Moskowitz, J., Palley, C. S., \& Churgin, S. (1981). A Review of 127 Drug Abuse Prevention Program Evaluations. Journal of Drug Issues, 22, 17-44.

Sheppard, M. A., Goodstadt, M. S. \& Williamson, B. (1985). Drug Education: Why We Have so Little Impact. Journal of Drug Education, 15(1), 1-6.

Sheppard, M. A., Goodstadt, M. S. \& Willett, M. M. (1987). The Drug Education - Drug Use Dilemma. Journal of Drug Education, 17(3), 197-200.

Silverstein, N. A., Derivan, W. E. \& Hugaboom, A. S. (1986). The state of the Art of Drug Prevention Programs: A Five Year Retrospective of school curricula. Conference Paper from the Ninth World Conference of Therapeutic Communities. (ERIC Document Reproduction Service No. ED 274910).

Stewart, R. B. (1974). Teaching Facts About Drugs: Pushing or Preventing? Journal of Educational Psychology, 66, 189-201.

Sullivan, A. P., Guglielmo, R. \& Lilly, L., (1986). Evaluating Prevention and Intervention Procedures. Journal of Drug Education, 16(1), 91-98.

Swisher, J. D. (1979). Handbook on Drug Abuse. Washington, D. C.: National Institute on Drug Abuse.

Swisher, J. D. (1974). The Effectiveness of Drug Education: Conclusions Based on Experimental Evaluations. ontario: Addiction Research Foundation, pp. 147-160.

Swisher, J. D. \& Hu, T. (1983). Alternatives to Drug Abuse: Some Are and Some Are Not. Preventing Adolescent Drug Abuse: Intervention Strategies. Research Monograph Series No. 47, pp. 141-153. Rockville, MD: National Institute on Drug Abuse.

Tobler, N. (1986). Meta-Analysis of 143 Adolescent Drug Prevention Programs: Quantitative outcome Results of Program Participants Compared to a Control or Comparison Group. Journal of Drug Issues, 16, 537-567.

Watson, D. (1988, March). The Greatest Risk of All. Educational Leadership, pp. 16-17. 
Wehlage, G. G., Rutter, R. A. \& Turnbaugh, A. (1987, March) . A Program Model for At-Risk High School students, Educational Leadership, pp. 70-73.

Werch, c. E., Gorman, D. R., Marty, P. J., Forbess, J. \& Brown, B. (1987, August). Effects of the BogusPipeline on Enhancing validity of Self-Reported Adolescent Drug Use Measures. Journal of School Health, 56 (6), 232-236.

Wolford, C. \& Swisher, J. D. (1986). Behavioral Intention as an Indicator of Drug and Alcohol Use. Journal of Drug Education, 16(4), 305-326.

Yin, R. K. (1987). Case Study Research: Design and Methods. Beverly Hills, CA: Sage Publications, Ltd. 
APPENDIX 1

DOCUMENTS 
APPENDIX 1-A

DRAFT SURVEY DOCUMENT SENT TO EDUCATIONAL SERVICE DISTRICT PERSONNEL AND LOCAL DISTRICT DRUG EDUCATION SPECIALISTS

FOR REVIEW AND COMMENTS 
APPENDIX 1-A

\section{SURVEY OF DRUG EDUCATION PROGRAMS FOR WASHINGTON STATE HIGH SCHOOLS}

SCHOOL DISTRICT

NAME OF HIGH SCHOOL

SCHOOL ADDRESS

SCHOOL PHONE

PERSON COMPLETING SURVEY

POSITION

\section{DATE THAT SURVEY IS COMPLETED}

REMINDER: Please answer all of the following questions as completely as possible. If information is not available, please indicate that. Thank you for completing this survey.

1. Approximate number of students enrolled in grades 10-12 during the 1987-88 school year:

Grade 10:

Grade 11:

Grade 12:

Grade 10-12 Total:

2. Please check which grade levels (if any) where all students received formal drug education instruction during the 1987-88 school year:

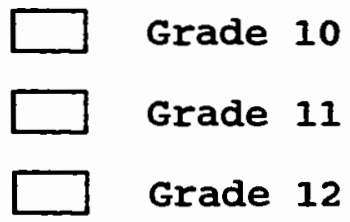

3. During the 1987-88 school year, did your high school have an established program for identifying students who are harmfully involved with alcohol and/or other drugs?

\section{YES}


4. If the answer to Question 3 was yes, which of the following staff members received formal training in identification strategies for students who are harmfully involved with alcohol and/or other drugs?

$\square$ Administrators $\square$ Teachers

$\square$ Counselors $\square$ others (Please specify)

5. Does your high school have a student peer counseling program that includes intervention strategies for students who are harmfully involved with alcohol and/or other drugs?

$\square$ YES

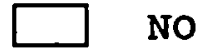

6. Does your school contract with a private agency to identify students who are harmfully involved with alcohol and/or other drugs?

$\square$ YES

No

7. Please estimate the number of students during the 1987-88 school year that were identified as being harmfully involved with alcohol and/or other drugs?

Grade 10:

Grade 11:

Grade 12:

Grade 10-12 Total:

8. Of the students identified in question 6 , how many of these students were referred to special services such as counseling and/or treatment for chemical dependency?

Referred to Treatment (if available)

Grade 10:

Grade 11:

Grade 12:

Grade 10-12 Total: 
APPENDIX 1-B

THANK YOU LETTER TO DRUG EDUCATION PERSONNEL WITH EDUCATIONAL SERVICE DISTRICTS AND INDIVIDUALS

IN LOCAL DISTRICTS THAT ASSISTED IN SURVEY DEVELOPMENT 
APPENDIX 1-B

October 14,1988

'F1'

'F2"

"F3"

${ }^{\wedge} \mathrm{F} 4{ }^{\wedge}$

Dear 'F5^:

Thank you for reviewing the Drug Education survey we are developing with the Bureau of Alcohol and substance Abuse. I have attached a copy of the final survey form that will be mailed to each secondary school in our state next week. Any support and assistance that you can provide in encouraging district participation would be greatly appreciated.

When the survey data has been collected, you will be provided with a summary of results for your region as well as the state as a whole. Please call if you have any questions regarding this information, and thanks again for your help.

sincerely,

Todd Herberg, Administrative Assistant for Instructional Services

TH: nlc 
DRUG EDUCATION CONTACTS WITHIN EDUCATIONAL SERVICE DISTRICTS

Educational Service

District 101

Ms. Jackie Beck

West 1025 Indiana Avenue

Spokane, WA 99205-4562

Educational Service

District 105

Ms. Jane Gutting, Curriculum Consultant

33 South 2nd Avenue

Yakima, WA 98902

Educational Service

District 112

Mr. Dick Yule, Assistant Superintendent

1313 N.E. 134th Street

Vancouver, WA 98685

Educational Service District 113

Mr. Russ Neff, Administrative Assistant

601 McPhee Road S.W.

Olympia, WA 98502

Educational service

District 114

Mr. John Hughes, Director of Drug Education

105 National Avenue North

Bremerton, WA 98312

Educational Service

District 121

Ms. Nancy Carr

12320 - 80th Avenue South

Seattle, WA 98178

Educational Service

District 121

Ms. Corine olson, Health Education

12320 - 80th Avenue South

seattle, WA 98178
Educational Service

District 123

Ms. Louise Gustafson, staff Development Consultant

124 South Fourth

Pasco, WA 99301

Educational Service

District 123

Ms. Sue Chadwick, GM Consultant

124 South Fourth

Pasco, WA 99301

North Central Educational Service District

Ms. Carol strong

P. O. Box 1847

Wenatchee, WA 98801

Educational Service

District 189

Mr. Lauriston Baker

205 Stewart Road

Mount Vernon, WA 98273

Everett School District

Mr. Pat Aaby

P. O. Box 2098

Everett, WA 98203

Seattle School District

Mr. Lin Carlson

815 - 4th Avenue North

Seattle, WA 98109 
APPENDIX 1-C

INITIAL SURVEY PACKAGE AND LETTER OF INSTRUCTIONS SENT TO TEN OREGON SCHOOL DISTRICTS AND VARIOUS WASHINGTON STATE ADMINISTRATORS AS A PILOT TEST FOR THE SURVEY BEING SENT TO ALL WASHINGTON STATE'S SECONDARY PUBLIC SCHOOL FOR SCHOOL YEAR 1987-88 
APPENDIX 1-C

SURVEY OF DRUG EDUCATION PROGRAMS IN WASHINGTON STATE'S SECONDARY PUBLIC SCHOOLS FOR SCHOOL YEAR 1987-88

Thank you for taking time to complete and return this survey. The information collected from this statewide survey will be used to assess current drug education efforts in Washington state and develop strategies for improving our existing programs as well as be used to prepare a report for the January 1989 State Legislature. All individual school survey data will be confidential. Only cumulative data from participating secondary schools will be published.

(PLEASE PRINT CLEARLY - USE INK ONLY)

SCHOOL DISTRICT

NAME OF SCHOOL

SCHOOL ADDRESS

SCHOOL PHONE

PERSON COMPLETING SURVEY

POSITION

DATE THAT SURVEY IS COMPLETED

SURVEY INSTRUCTIONS: Please answer all of the following questions as completely as possible by checking the appropriate boxes. Thank you again for completing this survey.

1. Please indicate which of the following best represents the configuration of your school?

$\square$ Middle school

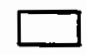

Junior High School

Junior-Senior High School
High School

Alternative Program

2. Approximate number of individual students in each grade that were enrolled in your building during the 1987-88 school year (give estimates for grade levels in your school only):

Grade $6:$
Grade $7:$
Grade $8:$
Grade $9:$

Grade 10:

Grade 11:

Grade 12:

Building Total: 
The following question refers to formal drug education instruction programs. For the purposes of this study, a formal drug education instruction program will be defined as an instructional program that is made available to all students at that grade level, and the program includes at least five hours of formal instruction. Examples of formal drug education instruction programs include: Here's Looking at You Two, Here's Looking at You 2,000 and Refusal Skills.

3. Please indicate which grade levels in your school have a formal drug education instruction program for students?

$\begin{array}{lll}\square & \text { Grade } & 6 \\ \square & \text { Grade } & 7 \\ \square & \text { Grade } & 8 \\ \square & \text { Grade } & 9\end{array}$

Questions 4 - 9 deal with programs designed to identify students who are harmfully involved with alcohol and/or other drugs. Identification programs teach individuals how to recognize particular student characteristics and behaviors that may indicate harmful involvement with alcohol and/or other drugs. For the purposes of this survey, formal training in identification must include at least two hours of formal instruction in identification strategies. Some examples of training programs for the identification of students who are harmfully involved with alcohol and/or other drugs include student assistance program training and drug and alcohol intervention training.

4. During the 1987-88 school year, did your school have an established program for identifying students who are harmfully involved with alcohol and/or other drugs?

$$
\text { Yes } \square \text { No }
$$

5. If yes, during which school year was this program put into place at your school?

6. Do building administrators in your school receive formal training in identification programs for students who are harmfully involved with alcohol and/or other drugs?

Yes $\square$ No

7. Do counselors in your school receive formal training in identification programs for students who are harmfully involved with alcohol and/or other drugs beyond their required college course work?

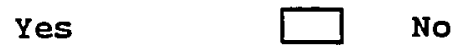


8. Do selected teachers, such as health instructors or student assistance team members, in your school receive formal training in identification programs for students who are harmfully involved with alcohol and/or other drugs?

Yes $\square$ No

9. Do all teachers in your school receive formal training in identification programs for students who are harmfully involved with alcohol and/or other drugs?

Yes

No

Question 10 deals with student peer assistance programs that include activities related to substance abuse among students. Examples of student peer assistance programs include Natural Helpers and Washington Teen Institute.

10. Does your school have a student peer assistance program that includes activities related to substance abuse among students?

Yes

No

Question 11 deals with student assessment programs. Student assessment programs are designed to gather and interpret information regarding a student's behavior, and determine the nature and extent of a student's possible involvement with alcohol and/or other drugs.

11. Does your school have a formal program whereby regular school personnel assess the behavior of students relative to the students being possibly harmfully involved with alcohol and/or other drugs?

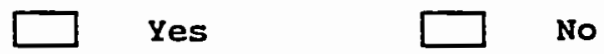

12. Does your school contract with an agency or other resource outside of the regular school system to assess students to determine whether or not they are harmfully involved with alcohol and/or other drugs?

Yes

No 
Question 13 deals with student referral programs. A student referral program would have formal processes in place that would refer those students who have been identified and assessed as being harmfully involved with alcohol and/or other drugs to some source of assistance. Referral programs could be conducted by school personnel, such as administrators and counselors, as well as other individuals who have been contracted for that service.

13. Does your school have a formal student referral process for students who have been identified and assessed as being harmfully involved with alcohol and/or other drugs?

Yes

No

Question 14 deals with reentry programs for students returning to school after counseling or treatment for chemical dependency. Examples of reentry programs include student support systems and aftercare counseling programs.

14. Does your school have an established reentry program for students returning to your school after having received counseling or treatment for alcohol and/or other drug abuse?

Yes

No

Question 15 deals with formal written drug policies. Formal written drug policies are documents that have been adopted by your local school board, and they describe specific programs that are in place or are to be implemented relative to student alcohol and/or other drug use and abuse.

15. During the 1987-88 school year, did your school have a formal written policy regarding student alcohol and/or other drug use?

$\square$ Yes $\square$ No

Question 16 deals with employee assistance programs. Employee assistance programs offer school district staff referral services for themselves and their families regarding such issues as the abuse of alcohol and/or other drugs.

16. During the 1987-88 school year, did your school district have an employee assistance program?

\section{Yes}

No 
17. What kinds of funds are used to finance your drug education program?

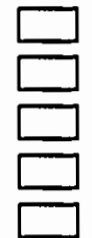

We have no program

Local district funds

SPI funds/grants

$\square$ Federal funds/grants

other state funds

other

18. Please estimate the number of students at each grade level during the 1987-88 school year that were identified as being harmfully involved with alcohol and/or other drugs (give estimates for grade levels in your school only)?

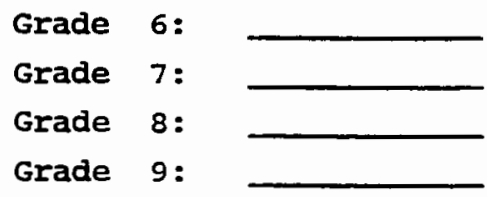

Grade 10:

Grade 11:

Grade 12:

Building Total:

19. Of the students identified in Question 18, how many of these students were referred to special services such as counseling and/or formal assessment regarding their harmful involvement with alcohol and/or other drugs (give estimates for grade levels in your school only)?

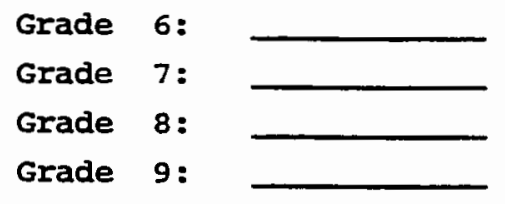

Grade 10:

Grade 11:

Grade 12:

Building Total:

20. Of the students identified in Question 19, how many of these students were subsequently referred to formal treatment for chemical dependency?

$\begin{array}{lll}\text { Grade } & 6: \\ \text { Grade } & 7: \\ \text { Grade } & 8: & \\ \text { Grade } & 9:\end{array}$

Grade 10:

Grade 11:

Grade 12:

Building Total:

Comments :

THANK YOU AGAIN FOR COMPLETING THIS SURVEY. Please use the enclosed envelope to return the survey to washington Bureau of Alcohol and Substance Abuse, $c / 0$ Educational Service District 114, 105 National Avenue North, Bremerton, WA 98312. 
September 13,1988

${ }^{\circ F 1} 1^{\circ}$
${ }^{\circ} 2^{\wedge}$
${ }^{\circ} 3^{\wedge}$
Dear 'F5^:

Thank you for agreeing to help us in our drug education survey efforts by reviewing the proposed survey materials. We are looking forward to this statewide survey of Washington state's secondary public schools as being of particular benefit to educational administrators and government agencies alike as we collect information regarding current drug education efforts in our schools. Information we collect will be prepared as a report to the January, 1989 Washington State Legislature.

I have attached a series of questions regarding the survey materials that I would like you to consider. Please complete the questionnaire and return it to me no later than September 19, 1988, using the enclosed stamped envelope.

Please call me if you have any questions regarding this information. On behalf of the washington state Bureau of Alcohol and substance Abuse and the secondary schools of washington state, thank you again for your assistance on this project.

sincerely,

Todd Herberg, Administrative Assistant

for Instructional Services

Enclosure

$\mathrm{TH}: \mathrm{nlc}$ 
Mr. Ben Evans

Student Assistance coordinator

Tigard High School

9000 S.W. Durham

Tigard, OR 97223

Mr. Dale Jones

Chenoweth High School

3601 West 10th

Dalles, OR 97058

Ms. Sharon Lindersmith

Aloha High School

P. O. BOX 200

Beaverton, OR 97075

Ms. Dorothy Smith

Sunset High School

P. O. Box 200

Beaverton, OR 97075

Mr. Len Carpenter

1698 S. W. Cherry Park Road

Troutsdale, OR 97060

Mr. Rich Correa

1200 North Main

Gresham, OR 97030

Mr. Harvey Hazen

1220 Indian Creek Road

Hood River, OR 97031

Dr. Terry stimac

Cascade Associates

74 East 18th, Suite 1

Eugene, OR 97401

Mr. Mike Meyers

Willamette High school

1801 Echo Hollow

Eugene, OR 97402 
DISCUSSION QUESTIONS REGARDING PROPOSED STUDENT SURVEY:

- Please give your observations about the attached cover letter as to whether or not it adequately explains the proposed project and how well it encourages people to participate in the survey.

- Please discuss the overall format of the survey including your observations as to whether or not the instructions are clear and the form itself is easy to use.

- Please comment as to whether or not the questions asked are appropriate. Are there questions we have asked we should omit? Are there questions we should ask that don't appear on the survey?

- Please discuss whether or not you think that the information requested will be readily available to school personnel who are given responsibility for completing this survey.

- Do you have any other comments regarding the proposed survey?

Thank you again for participating in the review of this proposed survey. Using the enclosed envelope, please return the answer sheet to Todd Herberg, ESD 114. 
APPENDIX 1-D

SURVEY DRAFT OF DRUG EDUCATION PROGRAMS IN WASHINGTON STATE'S SECONDARY PUBLIC SCHOOLS FOR SCHOOL YEAR 1987-88 


\section{APPENDIX 1-D \\ SURVEY OF DRUG EDUCATION PROGRAMS IN WASHINGTON STATE'S SECONDARY PUBLIC SCHOOLS FOR SCHOOL YEAR 1987-88}

Thank you for taking time to complete and return this survey. The information collected from this statewide survey will be used to assess current drug education efforts in Washington State and develop strategies for improving our existing programs as well as be used to prepare a report for the January 1989 State Legislature. All individual school survey data will be confidential. Only cumulative data from participating secondary schools will be published.

(PLEASE PRINT CLEARLY - USE INK ONLY)

\section{SCHOOL DISTRICT}

NAME OF SCHOOL

SCHOOL ADDRESS

SCHOOL PHONE

PERSON COMPLETING SURVEY

POSITION

DATE THAT SURVEY IS COMPLETED

SURVEY INSTRUCTIONS: Please answer all of the following questions as completely as possible by checking the appropriate boxes. Thank you again for completing this survey.

1. Please indicate which of the following best represents the configuration of your school.

Middle School

Junior High School

Junior-Senior High School
High School

Alternative Program

2. Approximate number of individual students in each grade that were enrolled in your building during the 1987-88 school year (give estimates for grade levels in your school only):

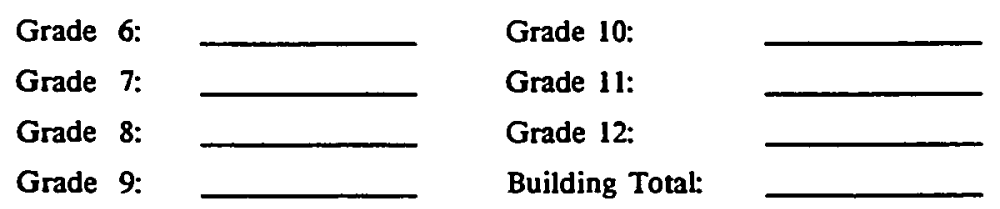

The following question refers to formal drug education instruction programs. For the purposes of this study, a formal drug education instruction program will be defined as an instructional program that is made available to all students at that grade level, and the program includes at least five hours of formal instruction. Examples of formal drug education instruction programs include: Here's Looking at You Two, Here's Looking at You 2,000 and Refusal Skills.

3. Please indicate which grade levels in your school have a formal drug education instruction program for students.

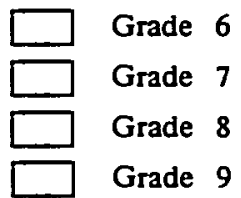

Grade 10

Grade 11

Grade 12 
Questions $4-9$ deal with programs designed to identify students who are harmfully involved with alcohol and/or other drugs. Identification programs teach individuals how to recognize particular student characteristics and behaviors that may indicate harmful involvement with alcohol and/or other drugs. For the purposes of this survey, formal training in identification must include at least two hours of formal instruction in identification strategies. Some examples of training programs for the identification of students who are harmfully involved with alcohol and/or other drugs include student assistance program training and drug and alcohol intervention training.

4. During the 1987-88 school year, did your school have an established program for identifying students who are harmfully involved with alcohol and/or other drugs?

Yes

No

5. If yes, during which school year was this program put into place at your school?

6. Do building administrators in your school receive formal training in identification programs for students who are harmfully involved with alcohol and/or other drugs?

Yes $\square$ No

7. Do counselors in your school receive formal training in identification programs for students who are harmfully involved with alcohol and/or other drugs beyond their required college course work?

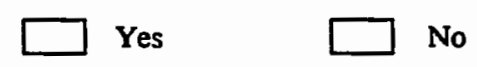

8. Do selected teachers, such as health instructors or student assistance team members, in your school receive formal training in identification programs for students who are harmfully involved with alcohol and/or other drugs?

Yes $\square$ No

9. Do all teachers in your school receive formal training in identification programs for students who are harmfully involved with alcohol and/or other drugs?

Yes $\square$ No

Question 10 deals with student peer assistance programs that include activities related to substance abuse among students. Examples of student peer assistance programs include Natural Helpers and Washington Teen Institute.

10. Does your school have a student peer assistance program that includes activities related to substance abuse among students? 
Question 11 deals with student assessment programs. Student assessment programs are designed to gather and interpret information regarding a student's behavior, and determine the nature and extent of a student's possible involvement with alcohol and/or other drugs.

11. Does your school have a formal program whereby regular school personnel assess the behavior of students relative to the students being possibly harmfully involved with alcohol and/or other drugs?

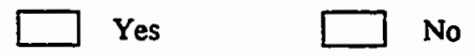

12. Does your school contract with an agency or other resource outside of the regular school system to assess students to determine whether or not they are harmfully involved with alcohol and/or other drugs?

Yes

No

Question 13 deals with student referral programs. A student referral program would have formal processes in place that would refer those students who have been identified and assessed as being harmfully involved with alcohol and/or other drugs to some source of assistance. Referral programs could be conducted by school personnel, such as administrators and counselors, as well as other individuals who have been contracted for that service.

13. Does your school have a formal student referral process for students who have been identified and assessed as being harmfully involved with alcohol and/or other drugs?

Yes

No

Question 14 deals with reentry programs for students returning to school after counseling or treatment for chemical dependency. Examples of reentry programs include student support systems and af tercare counseling programs.

14. Does your school have an established reentry program for students returning to your school after having received counseling or treatment for alcohol and/or other drug abuse?

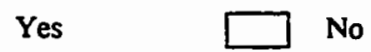

Question 15 deals with formal written drug policies. Formal written drug policies are documents that have been adopted by your local school board, and they describe specific programs that are in place or are to be implemented relative to student alcohol and/or other drug use and abuse.

15. During the 1987-88 school year, did your school have a formal written policy regarding student alcohol and/or other drug use?

Yes $\square$ No 
Question 16 deals with employee assistance programs. Employee assistance programs offer school district staff referral services for themselves and their families regarding such issues as the abuse of alcohol and/or other drugs.

16. During the 1987-88 school year, did your school district have an employee assistance program?

Yes $\square$ No

17. What kinds of funds are used to finance your drug education program?

$\begin{array}{ll}\square \text { We have no program } & \square \text { Federal funds/grants } \\ \square \text { Local district funds } & \square \text { County funds/grants } \\ \square \text { SPI funds/grants } & \square \text { Donations } \\ \square \text { Other State funds } & \\ \square \text { Other }\end{array}$

18. Please estimate the number of students at each grade level during the 1987-88 school year that were identified as being harmfully involved with alcohol and/or other drugs (give estimates for grade levels in your school only).

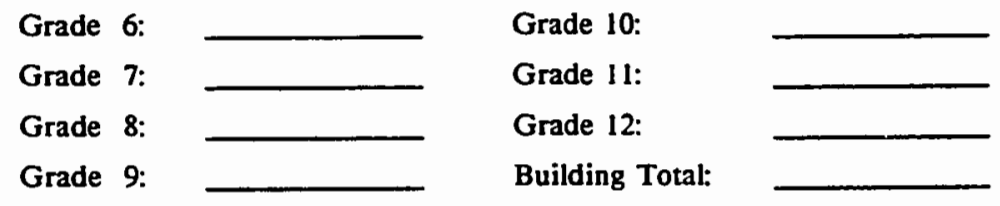

19. Of the students identified in Question 18, how many of these students were referred to special services within the school such as counseling regarding their harmful involvement with alcohol and/or other drugs (give estimates for grade levels in your school only)?

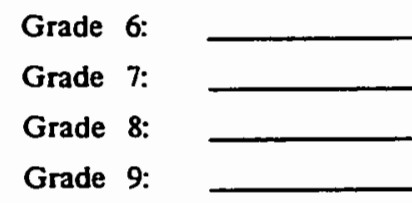

Grade 10:

Grade 11:

Grade 12:

Building Total: 
20. Of the students identified in Question 18, how many of these students were referred to special services outside of the school such as counseling regarding their harmful involvement with alcohol and/or other drugs (give estimates for grade levels in your school only)?

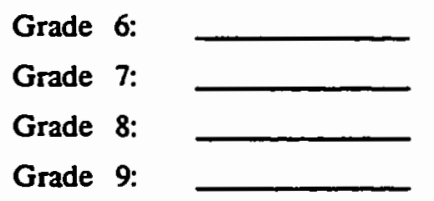

Grade 10:

Grade 11:

Grade 12:

Building Total:

21. Of the students identified in Questions 19 and 20, how many of these students were subsequently referred to formal assessment for chemical dependency?

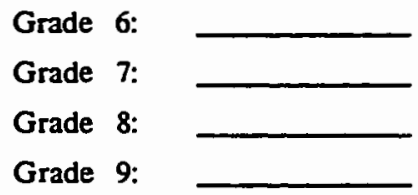

Grade 10:

Grade 11:

Grade 12:

Building Total:

22. Please estimate the number of students at each grade level during the 1987-88 school year that received formal treatment for chemical dependency (give estimates for grade levels in your school only).

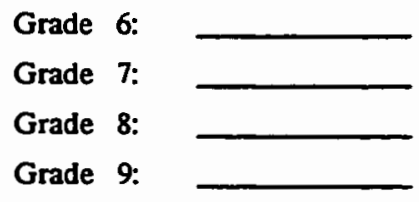

Grade 10:

Grade 11:

Grade 12:

Building Total:

Comments:

THANK YOU AGAIN FOR COMPLETING THIS SURVEY. Please use the enclosed envelope to return the survey to Washington Bureau of Alcohol and Substance Abuse, c/o Educational Service District 114, 105 National Avenue North, Bremerton, WA 98312. 
APPENDIX 1-E

FIRST LETTER TO ALL WASHINGTON STATE SECONDARY PRINCIPALS WITH INSTRUCTIONS FOR COMPLETING THE SURVEY 
October 14,1988

\section{APPENDIX 1-E}

Dear School Principal:

Enclosed is a survey of drug education programs for all secondary schools in the state of Washington that is being conducted by Educational Service District 114 and the Washington State Bureau of Alcohol and Substance Abuse. The survey is requesting information regarding drug education programs in your secondary school during the 1987-88 school year. The information from this statewide survey will be used to assess current drug education efforts in Washington state and to develop a status report on drug education programs in our secondary schools for the January 1989 state Legislature.

The enclosed survey should be completed by the building principal or his/her designee. It is important that the person completing this survey works with other school personnel who are knowledge-able about the information being requested. Please be sure that all of the questions are answered as completely as possible. If information is not available for certain questions, it is important that you indicate that.

Please return the completed survey in the enclosed envelope no later than October 28, 1988. All individual school survey data will be confidential. Only cumulative data from all secondary schools for each Educational Service District and the staff as a whole will be published. Each school participating in the survey will receive a copy of the cumulative results.

Thank you for taking the time to complete this survey. If you have any questions regarding this survey, please call me at (206) 479-0993 (SCAN 576-6399 or SEATTLE 464-5365).

sincerely,

Todd Herberg, Administrative Assistant for Instructional Services

Enclosure 


\section{APPENDIX 1-F}

SECOND LETTER TO ALI WASHINGTON STATE SECONDARY PRINCIPALS WHO HAD NOT RETURNED THEIR SURVEY AS OF OCTOBER 28, 1988 
November 2, 1988

APPENDIX 1-F

Dear School Principal:

As of October 14, 1988, you were mailed a survey that requested information about drug education programs in your school for the 1987-88 school year. The survey is part of a project being conducted by Educational service District 114 in cooperation with the Washington state Bureau of Alcohol and Substance Abuse. The project is designed to assess current drug education efforts in washington state and develop a status report on drug education programs in our secondary schools for the 1989 state Legislature.

Information from this survey will be of great value to educators and government officials alike as we examine what we can do in the future to better serve the students of Washington state in regard to drug education services. It is very important for our project that we receive information from all of Washington state's secondary schools. It will be difficult for us to be completely confident in our survey results if some schools have not participated.

our records indicate that as of November 1, 1988, we have not received a survey from your school. If you have already submitted your completed survey instrument, thank you very much for your cooperation. If you have not submitted this survey, please completed the attached survey and return it to us as soon as possible. Please remember that all individual school survey data will confidential. You will receive a copy of the statewide cumulative results as well as cumulative results from your ESD region sometime in early January.

Thank you again for helping us serve the children of Washington state by taking the time to complete this survey. If you have any questions regarding this survey, please call me at (206) 479-0993 (SCAN 576-6399 or SEATTLE 464-5365).

\section{sincerely,}

Todd Herberg, Administrative Assistant for Instructional Services

Enclosure 


\begin{abstract}
APPENDIX 1-G
DISTRIBUTION LIST OF WASHINGTON STATE SECONDARY PUBLIC SCHOOLS
\end{abstract}




\begin{abstract}
APPENDIX 1-G
EDUCATIONAL SERVICE DISTRICT 114

DRUG EDUCATION SURVEY DISTRIBUTION LIST - ALPHABETICAL ORDER OCTOBER, 1988
\end{abstract}

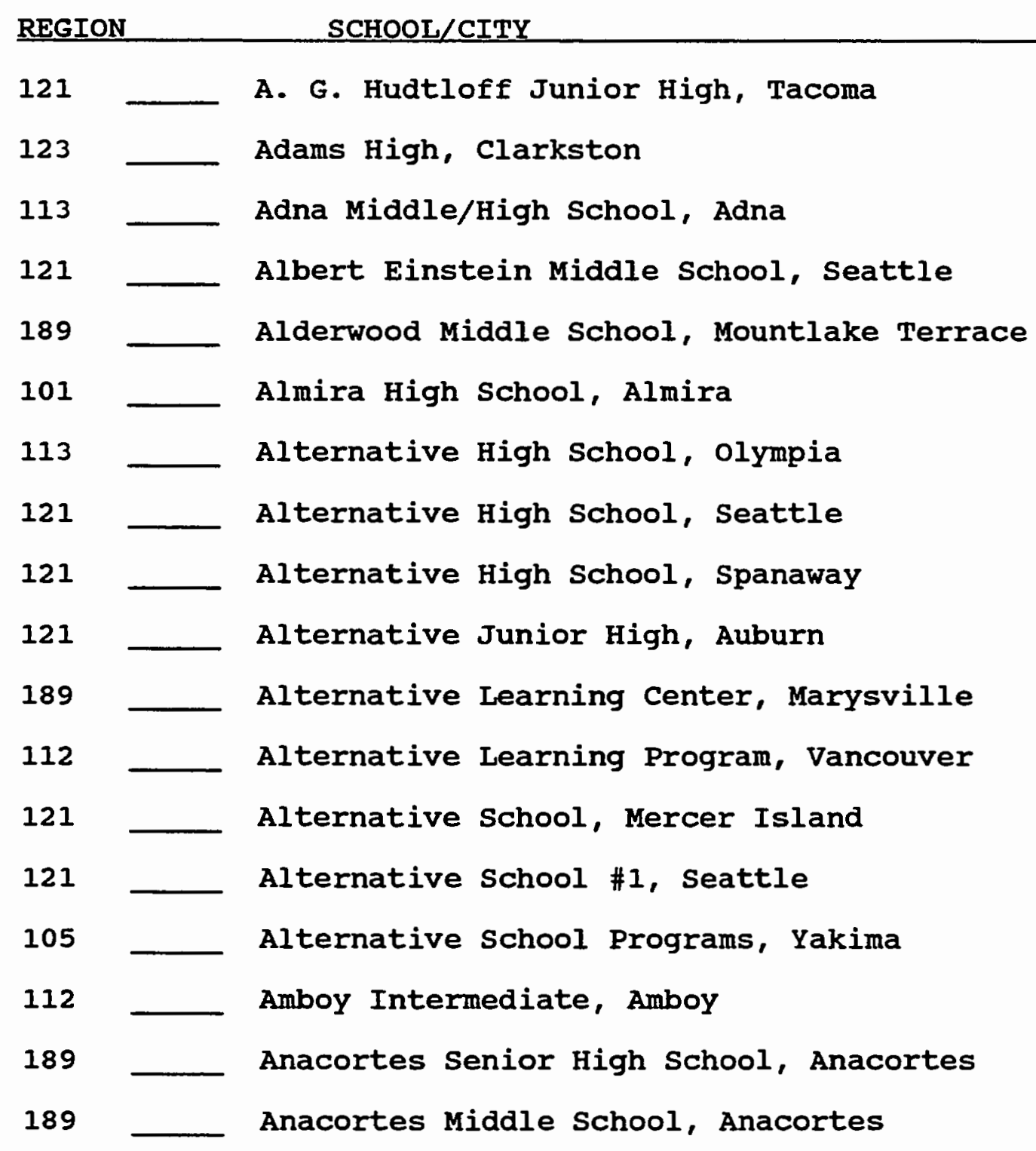




\section{REGION}

101

189

189

189

121

123

121

121

121

121

121

112

121

189

121

121

121

105

189

189

121

101

114

114

NC
SCHOOL/CITY

Argonne Junior High, Spokane

Arlington Alternative School, Arlington

Arlington High School, Arlington

Arlington Intermediate, Arlington

Asa Mercer Middle School, Seattle

Asotin Junior-Senior High, Asotin

Auburn Senior High School, Auburn

Aylen Junior High, Puyallup

Bainbridge High School, Bainbridge Island

Baker Middle School, Tacoma

Ballard High School, Seattle

Battle Ground High, Battle Ground

Bellevue Senior High, Bellevue

Bellingham High School, Bellingham

BEST High School, Kirkland

Bethel High School, Spanaway

Bethel Junior High, Spanaway

Bickleton High School, Bickleton

Blaine High School, Blaine

Blaine Middle School, Blaine

Bothell Senior High School, Bothell

Bowdish Junior High, Spokane

Bremerton High School, Bremerton

Bremerton Middle School, Bremerton

Brewster High School, Brewster 
121

NC

189

189

112

121

113

123

121

NC

112

189

112

121

189

NC

NC

112

112

114

121

114

114

101

113
Briarcrest Intermediate, Seattle

Bridgeport Junior-Senior High, Bridgeport Brier Terrace Middle School, Lynnwood Burlington-Edison High, Burlington

Camas High School, Camas

Canyon Park Junior High, Bothell

Capital High School, olympia

Carmichael Junior High, Richland

Cascade Junior High, Auburn

Cascade Junior-Senior High, Leavenworth

Cascade Junior High, Vancouver

Cascade High School, Everett

Cascade Middle School, Longview

Cascade Middle School, Seattle

Cascade Middle School, Sedro-Woolley

Cashmere High School, Cashmere

Cashmere Middle School, Cashmere

Castle Rock High School, Castle Rock

Castle Rock Middle School, Castle Rock

Cedar Heights Junior High, Port Orchard

Cedarcrest Junior High, Spanaway

Central Kitsap High School, Silverdale

Central Kitsap Junior High, Silverdale

Central Valley High School, Veradale

Centralia High School, Centralia 
Centralia Junior High School, Centralia

121

Charles A. Lindbergh High, Renton

NC

Chelan Middle School, Chelan

NC

Chelan Senior High School, Chelan

101

Cheney High School, Cheney

101

Cheney Junior High, Cheney

NC

Chief Moses Junior High, Moses Lake

114

Chimacum High School, Chimacum

114

Chimacum Junior High, Chimacum

121

Chinook Middle School, Des Moines

113

Chinook Middle School, Lacey

121

Chinook Middle School, Bellevue

114

Clallam Bay High, Sekiu

105

cle Elum High School, cle Elum

121

Cleveland High School, Seattle

121

Clover Park High School, Tacoma

101

Colfax High School, Colfax

189

College Place Middle School, Lynnwood

101

Colton High School, colton

NC

Columbia Basin Alternative High, Moses Lake

123

Columbia High School, Burbank

101

Columbia High, Hunters

112

Columbia High School, white Salmon

123 Columbia Middle School, Burbank

112 Columbia River High School, Vancouver 


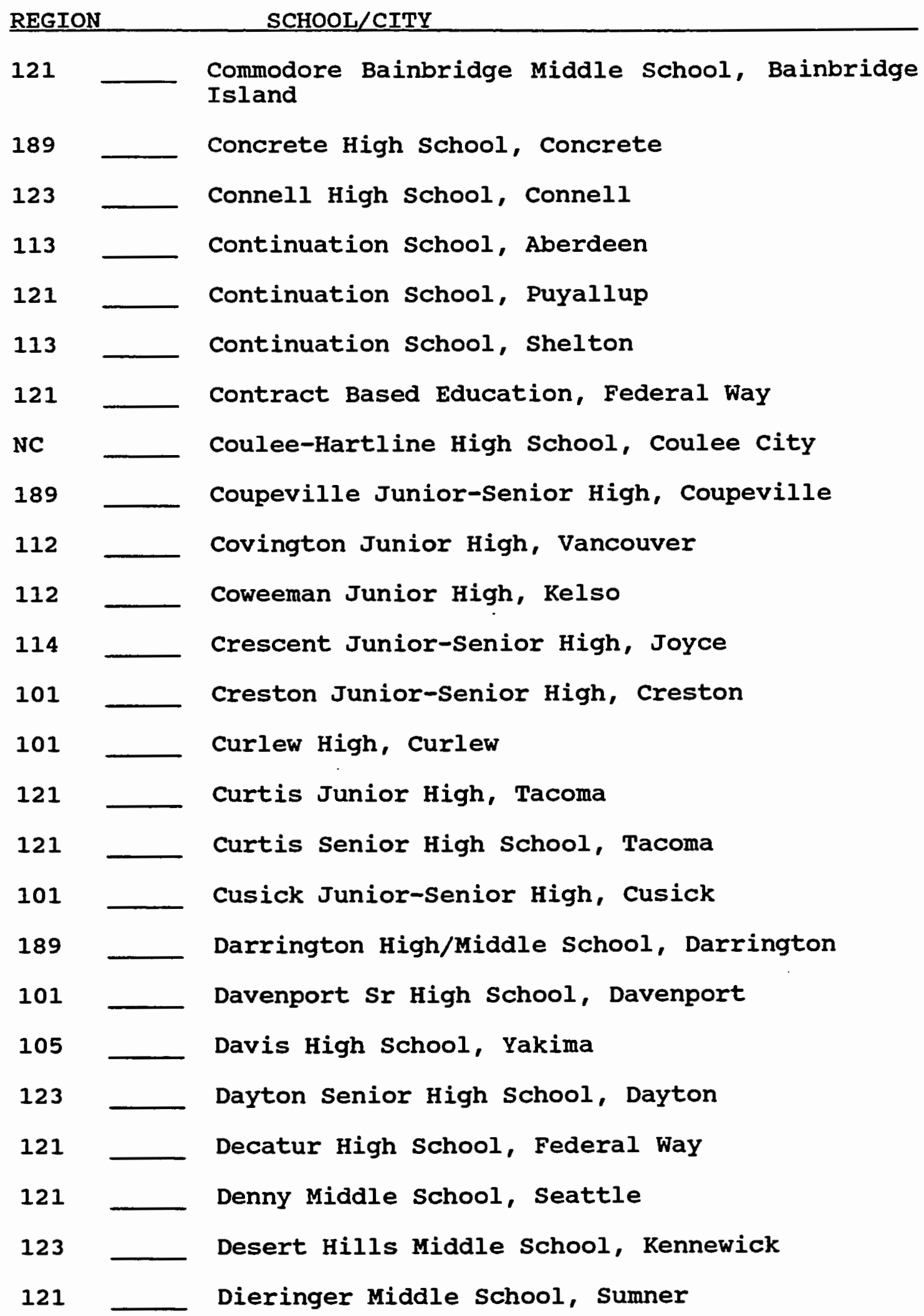




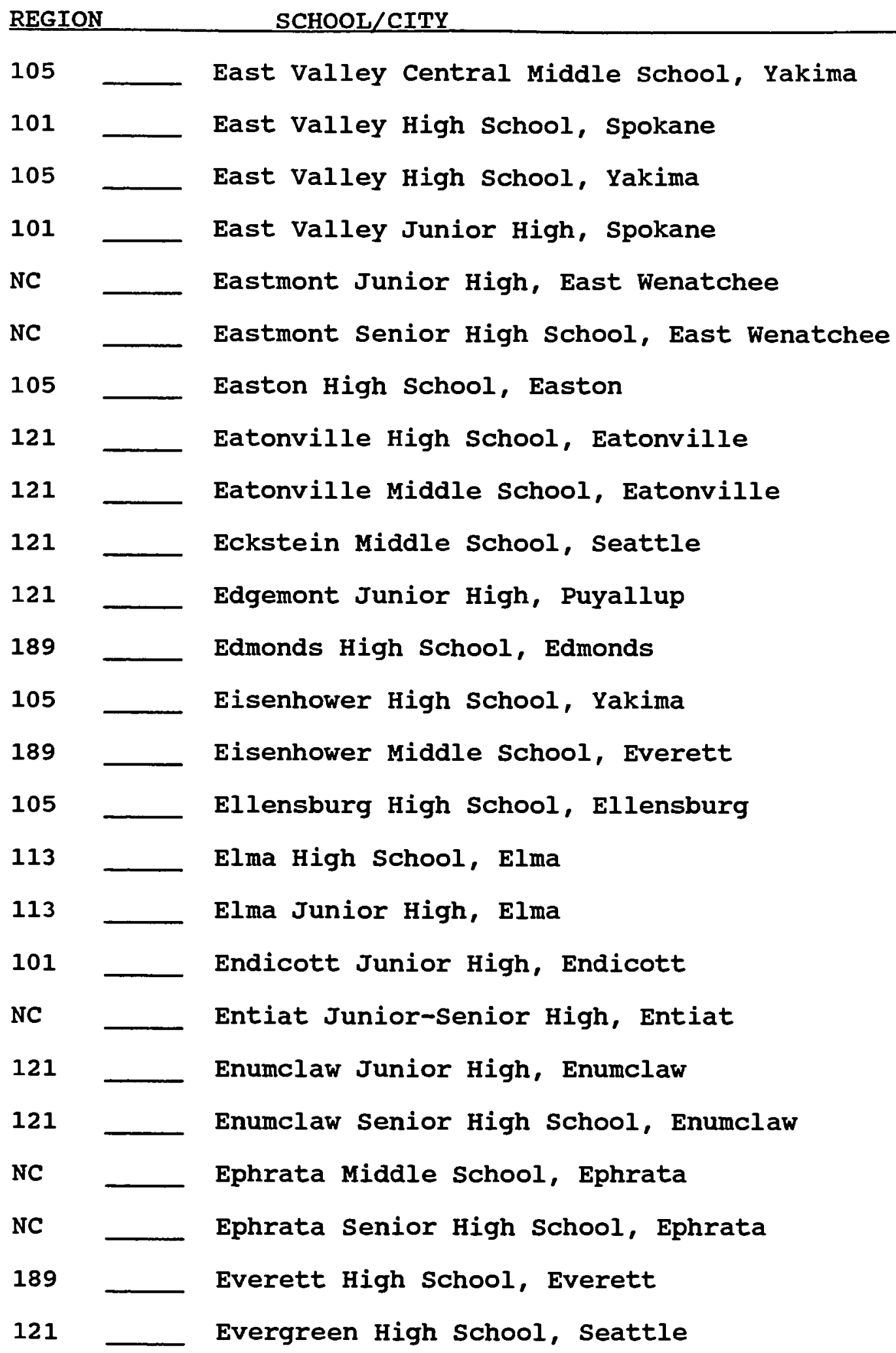

105

101

105

101

NC

NC

105

121

121

121

121

189

105

189

105

113

113

101

NC

121

121

NC

NC

189

121

East Valley Central Middle School, Yakima

East Valley High School, Spokane

East Valley High School, Yakima

East Valley Junior High, Spokane

Eastmont Junior High, East Wenatchee

Eastmont Senior High School, East Wenatchee

Easton High School, Easton

Eatonville High School, Eatonville

Eatonville Middle School, Eatonville

Eckstein Middle School, Seattle

Edgemont Junior High, Puyallup

Edmonds High School, Edmonds

Eisenhower High School, Yakima

Eisenhower Middle School, Everett

Ellensburg High School, Ellensburg

Elma High School, Elma

Elma Junior High, Elma

Endicott Junior High, Endicott

Entiat Junior-Senior High, Entiat

Enumclaw Junior High, Enumclaw

Enumclaw Senior High School, Enumclaw

Ephrata Middle School, Ephrata

Ephrata Senior High School, Ephrata

Everett High School, Everett

Evergreen High School, Seattle 


\section{REGION}

112

121

101

189

189

189

114

121

189

121

121

121

121

114

114

101

112

121

189

121

121

105

121

101

189
SCHOOL/CITY

Evergreen High School, Vancouver

Evergreen Junior High, Redmond

Evergreen Junior High, Veradale

Evergreen Middle School, Everett

Explorer Junior High, Everett

Fairhaven Middle School, Bellingham

Fairview Junior High, Bremerton

Federal Way High School, Federal Way

Ferndale High School, Ferndale

Ferrucci Junior High, Puyallup

Fife High School, Tacoma

Finn Hill Junior High, Kirkland

Firwood Junior-Senior High, Fort Steilacoom

Forks Intermediate School, Forks

Forks Junior-Senior High, Forks

Fort Colville, Colville

Fort Vancouver High School, Vancouver

Foster Senior High School, Seattle

Frank Wagner Intermediate, Monroe

Franklin Pierce High School, Tacoma

Franklin High School, Seattle

Franklin Middle School, Yakima

Fred Nelsen Middle School, Renton

Freeman High School, Rockford

$$
\text { Friday Harbor Middle/High school, Friday }
$$


NC

112

121

101

101

123

101

121

121

121

112

101

105

105

121

121

NC

113

105

105

105

189

189

121

112
Frontier Junior High, Moses Lake

Gaiser Middle School, Vancouver

Garfield High School, Seattle

Garfield-Palouse High, Palouse

Garfield-Palouse Middle School, Garfield

Garrison Junior High, Walla Walla

Garry Junior High, Spokane

GATES, Tacoma

Gault Middle School, Tacoma

Gig Harbor High School, Gig Harbor

Glenwood High, Glenwood

Glover Junior High, Spokane

Goldendale High School, Goldendale

Goldendale Middle School, Goldendale

Goodman Middle School, Gig Harbor

Governor John Rogers High, Puyallup

Grand Coulee Dam Junior High, Grand Coulee

Grand Mound Middle School, Rochester

Grandview High School, Grandview

Grandview Middle School, Grandview

Granger High School, Granger

Granite Falls High School, Granite Falls

Granite Falls Middle School, Granite Falls

Gray Middle School, Tacoma

Grays River Valley, Rosburg 


\section{REGION}

101

121

123

101

114

121

121

105

121

123

121

121

112

113

113

113

101

123

112

121

112

121

101

121

121
SCHOOL/CITY

Greenacres Junior High, Greenacres

Hamilton Middle School, Seattle

Hanford Secondary School, Richland

Harrington High School, Harrington

Hawkins Middle School, Belfair

- Henderson Bay Alt. High School, Gig Harbor

Henry Foss Senior High School, Tacoma

Highland High School, Cowiche

Highland Middle School, Bellevue

Highlands Middle School, Kennewick

Highline High School, Seattle

Highline Satellite School, seattle

Hockinson Middle School, Brush Prairie

Hood Canal Junior High, Shelton

Hoquiam High School, Hoquiam

Hoquiam Middle School, Hoquiam

Horizon Junior High, Spokane

Housel Middle School, Prosser

Hudson's Bay High School, Vancouver

Hunt Middle School, Tacoma

Huntington Junior High, Kelso

Illahee Junior High, Federal Way

Inchelium, Inchelium

Indian Heritage High School, Seattle

Inglemoor Sr High School, Bothell 
121

121

121

121

121

121

121

121

112

113

112

101

101

101

121

101

123

114

101

121

123

112

121

123

121
Ingraham High School, Seattle

Interlake Center, Bellevue

slander Middle School, Mercer Island

Issaquah Alternative High School, Issaquah

Issaquah High School, Issaquah

Issaquah Middle School, Issaquah

Iva Alice Mann Junior High, Tacoma

Jason Lee Middle School, Tacoma

Jason Lee Middle School, Vancouver

Jefferson Middle School, Olympia

Jemtegaard Middle School, Washougal

Jenkins Middle School, Chewelah

Jenkins Senior High School, Chewelah

Joel E. Ferris High School, Spokane

John H. McKnight Middle School, Renton

John R. Rogers High School, Spokane

John Sager Middle School, College Place

John Sedgwick Junior High, Port Orchard

Joseph Jantsch High School, Spokane

Juanita High School, Kirkland

Kahlotus Junior-Senior High, Kahlotus

Kalama Junior-Senior High School, Kalama

Kalles Junior High, Puyallup

Kamiakin High School, Kennewick

Kamiakin Junior High, Kirkland 
Kellogg Middle School, Seattle Kelso High School, Kelso

121 Ken Junior High, Kent Kenmore Junior High, Bothell Kennewick High School, Kennewick Kent Continuation School, Kent Kent-Meridian Sr High School, Kent Kentridge Senior High School, Kent Kentwood Senior High School, Kent Kettle Falls High School, Kettle Falls

101 Kettle Falls Middle School, Kettle Falls Key Peninsula Middle School, Lakebay

121 Kilo Junior High, Auburn Kiona-Benton City High, Benton City Kiona-Benton City Middle School, Benton City Kirkland Junior High, Kirkland Kirkwood-Mt. Adams Intermediate, Toppenish Kittitas Junior-senior High, Kittitas Klickitat High School, Klickitat Kopachuck Middle School, Gig Harbor La Center High School, La Center La Center Intermediate, La Center La Conner High School, La Conner La Conner Middle School, La Conner 101 Lacrosse High School, Lacrosse 
REGION

113

NC

189

189

121

121

121

189

121

101

189

112

189

121

101

105

112

101

NC

121

101

101

123

101

121
SCHOOL/CITY

Lake Quinalt High School, Amanda Park

Lake Roosevelt High, Coulee Dam

Lake Stevens Middle School, Everett

Lake Stevens Senior High School, Everett

Lake Washington High School, Kirkland

Lakeridge Junior High, Sumner

Lakes High School, Tacoma

Lakewood High School, Lakewood

Lakota Junior High, Federal Way

Lamont Middle School, Lamont

Langley Middle School, Langley

Laurin Intermediate, Vancouver

LaVenture School, Mount Vernon

Leota Junior High, Woodinville

Lewis and Clark High School, Spokane

Lewis and Clark Middle School, Yakima

Lewisville Intermediate, Battle Ground

Libby Junior High, Spokane

Liberty Bell High School, Twisp

Liberty High School, Issaquah

Liberty High School, Spangle

Liberty Junior High, Spangle

Lincoln Middle School, clarkston

Lincoln Middle School, Pullman

Lincoln Senior High School, Tacoma 
Lind Junior-Senior High, Lind

Lochburn Junior High, Tacoma

Lopez Junior-Senior High, Lopez

112

Lyle High-Middle School, Lyle

Lynden High School, Lynden

Lynden Middle School, Lynden

Lynnwood High School, Lynnwood

105

Mabton High School, Mabton

121

Madison Middle School, Seattle

NC

Mansfield High School, Mansfield

NC

Manson Junior-Senior High, Manson

Marcus Whitman Junior High, Port orchard

Mariner High School, Everett

112

Mark Morris High School, Longview

Mary M. Knight High, Matlock

101

Mary Walker Senior High, Springdale

189

Marysville Junior High, Marysville

189

Marysville Middle School, Marysville

189 Marysville-Pilchuck High School, Marysville

121 Mason Middle School, Tacoma

121 Mattson Junior High, Kent

121 Maywood Middle School, Issaquah

121 Mcclure Middle School, Seattle

123 McFarland Junior High, Othello

121 McIlvaigh Middle School, Tacoma 


\section{REGION}

123

112

121

101

101

189

189

121

101

101

121

121

113

121

189

121

189

NC

113

189

189

113

112

105

121
SCHOOL/CITY

McLoughlin Junior High, Pasco

McLoughlin Middle School, Vancouver

McMurray Intermediate School, Vashon

Mead Junior High, Mead

Mead Senior High School, Spokane

Meadowdale High School, Lynnwood

Meadowdale Middle School, Edmonds

Meany Middle School, Seattle

Medical Lake High School, Medical Lake

Medical Lake Middle School, Medical Lake

Meeker Junior High, Renton

Meeker Middle School, Tacoma

Menlo Middle School, Menlo

Mercer Island High School, Mercer Island

Meridian High School, Bellingham

Meridian Junior High, Kent

Meridian Middle School, Lynden

Methow Valley Middle School, Twisp

Miller Junior High, Aberdeen

Monroe High School, Monroe

Monroe Middle School, Monroe

Montesano Junior-Senior High, Montesano

Monticello Middle School, Longview

Morgan Middle School, Ellensburg

Morris Ford Junior High, Tacoma 
105

113

NC

113

113

189

121

121

121

189

112

101

189

105

105

105

113

112

112

121

112

114

189

101

101
Morris Schott Middle School, Mattawa

$$
\text { Morton Junior-Senior High, Morton }
$$

Moses Lake Senior High, Moses Lake

Mossyrock High School, Mossyrock

Mossyrock Middle School, Mossyrock

Mount Baker Junior-Senior, Deming

Mount Rainier High School, Des Moines

Mount Si High School, Snoqualmie

Mount Tahoma Senior High School, Tacoma

Mount Vernon High School, Mount Vernon

Mountain View High School, Vancouver

Mountain View Junior High, Newman Lake

Mountlake Terrace High, Mountlake Terrace

Naches Valley High School, Naches

Naches Valley Intermediate, Naches

Naches Valley Middle School, Naches

Napavine High School, Napavine

Naselle Junior-Senior High, Naselle

Naselle-Grays River Vly High, Naselle

Nathan Hale High School, Seattle

Natural High School, Longview

Neah Bay High, Neah Bay

Nellie S. Milton Middle School, Eastsound

Newport High School, Newport

Newport Junior High, Newport 


\section{REGION}

121

113

189

101

189

189

113

113

113

101

114

114

114

113

101

121

121

101

121

189

189

189

101

121

113
SCHOOL/CITY

Newport Senior High, Bellevue

Nisqually Middle School, Lacey

Nooksack Valley Junior-Senior High, Nooksack

North Pines Junior High, Spokane

North Lake School, Lake Stevens

North Middle School, Everett

North River Junior-Senior High, Cosmopolis

North Beach Middle School, Ocean City

North Beach Senior High School, Moclips

North Central High School, Spokane

North Kitsap High School, Poulsbo

North Kitsap Middle School, Poulsbo

North Mason High School, Belfair

North Thurston High School, Lacey

Northport Junior-Senior High, Northport

Northshore Junior High, Bothell

Northstar Junior High, Kirkland

Northwood Junior High, Spokane

NOVA Alternative School, Seattle

Oak Harbor High School, Oak Harbor

Oak Harbor Junior High, Oak Harbor

Oak Harbor Middle School, Oak Harbor

Oakesdale High School, Oakesdale

Oakland Alternative School, Tacoma

Oakville High School, Oakville 
REGION

113

101

121

121

121

NC

NC

121

114

121

113

189

121

NC

NC

NC

113

189

NC

NC

121

121

123

105

112
SCHOOL/CITY

Ocosta Junior-Senior High, Westport

Odessa High School, Odessa

Odle Middle School, Bellevue

Off-Campus School, Auburn

Off-Campus School, Bellevue

Okanogan Middle School, Okanogan

Okanogan Serior High School, Okanogan

Oliver M. Hazen High, Renton

Olympic High School, Bremerton

Olympic Junior High, Auburn

olympic Midale School, Chehalis

Olympic View Junior High, Mukilteo

Olympus Northwest Middle School, Bellevue

Omak Alternative High School, Omak

Omak Middle School, Omak

Omak Senior High School, Omak

Onalaska High School, Onalaska

Orcas Island High School, Eastsound

Orchard High School, Wenatchee

oroville High School, Oroville

orting Middle School, Orting

orting Senior High School, orting

Othello High, Othello

Pace Alternative High School, Wapato

Pacific Junior High, Vancouver 


\section{REGION}

121

112

101

123

123

123

NC

113

121

121

189

121

123

113

121

NC

112

123

114

112

123

123

101

121

114
Pacific Middle School, Des Moines

Pan Terra Alternative School, Vancouver

Park Junior High, Spokane

Park Middle School, Kennewick

Pasco Alternative High School, Pasco

Pasco Senior High, Pasco

Pateros Junior-Senior High, Pateros

Pe Ell High School, Pe Ell

Peninsula High School, Gig Harbor

Perry G. Keithley Middle School, Tacoma

Phoenix Center for Ind Education, Everett

Pine Lake Middle School, Issaquah

Pioneer Junior High, Walla Walla

Pioneer Middle School, Shelton

Pioneer Middle School, Steilacoom

Pioneer Middle School, Wenatchee

Pleasant Valley Intermediate, Vancouver

Pomeroy Junior-Senior High, Pomeroy

Port Townsend High School, Port Towsend

Prairie High School, Brush Prairie

Prescott High School, Prescott

Prosser High School, Prosser

Pullman High School, Pullman

Puyallup Senior High School, Puyallup

Quilcene High School, Quilcene 


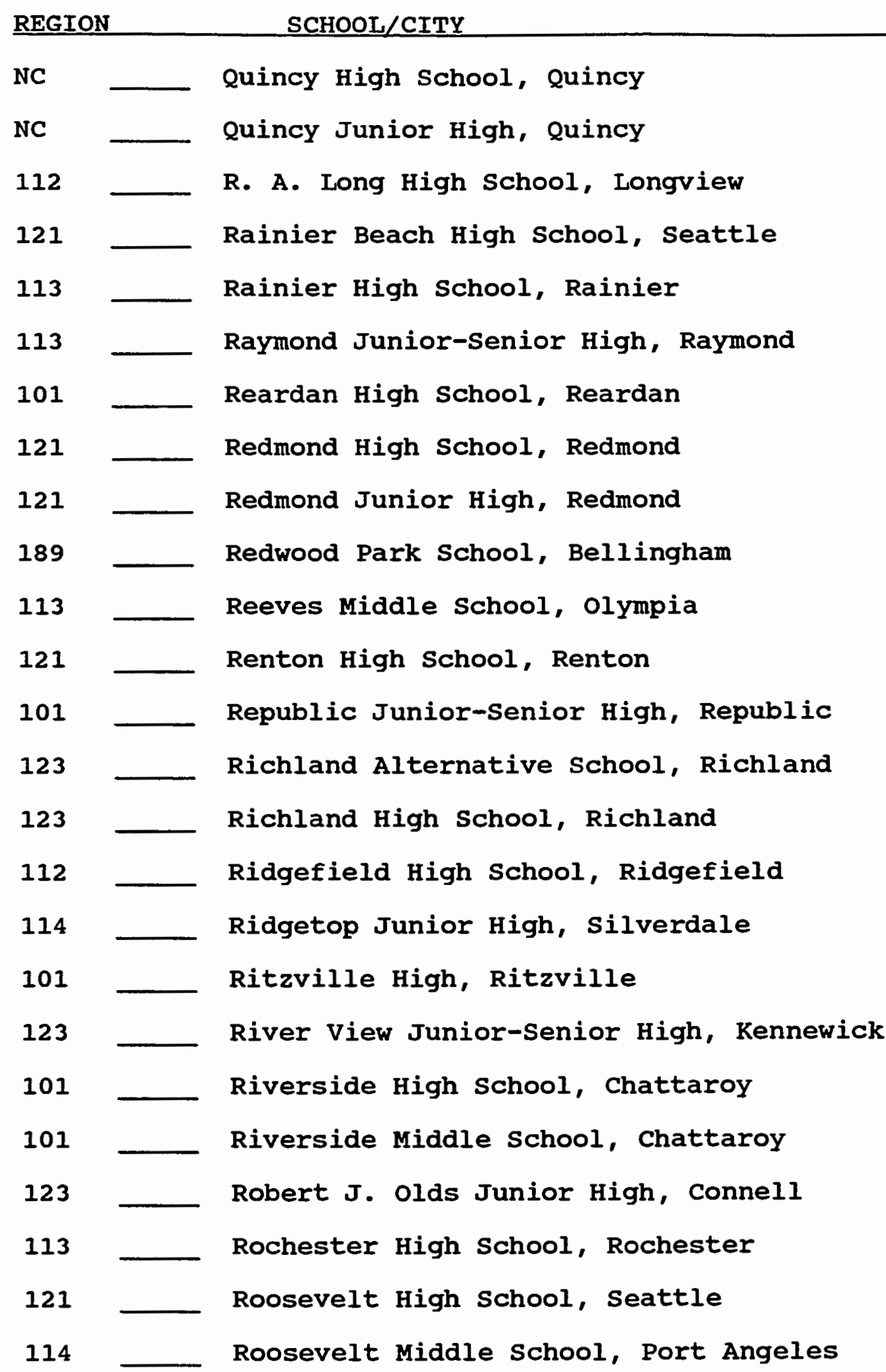


REGION

101

121

105

105

121

101

101

121

189

121

121

121

121

121

112

189

189

105

105

105

101

114

114

121

101

\section{SCHOOL/CITY}

Rosalia High School, Rosalia

Rose Hill Junior High, Redmond

Royal High School, Royal city

Royal Middle School, Royal city

Sacajawea Junior High, Federal Way

Sacajawea Junior High, Spokane

Salk Junior High, Spokane

Sammamish Senior High, Bellevue

Scriber Lake High School, Lynnwood

Sealth High School, Seattle

Seattle Alternative, Seattle

Seattle Alternative, seattle

Seattle Evening High School, Seattle

Secondary Alternative School, Bothell

Secondary Complex, Ilwaco

Sedro-Woolley Senior High, Sedro-Woolley

Sehome High School, Bellingham

Selah High School, Selah

Selah Intermediate, Selah

Selah Middle School, Selah

Selkirk Junior-Senior High, Ione

Sequim Middle School, Sequim

Sequim Senior High School, Sequim

Sequoia Junior High, Kent

Shadle Park High School, Spokane 
101

113

113

121

121

121

121

189

112

121

189

189

121

NC

114

121

189

121

121

123

101

101

101

101
Shaw Junior High, Spokane

Shelton Middle School, Shelton

Shelton Senior High School, Shelton

Shorecrest High School, Seattle

Shoreline Alternative, Seattle

Shorewood High School, Seattle

Showalter Middle School, Seattle

Shuksan Middle School, Bellingham

Shumway Middle School, Vancouver

Skykomish High School, Skykomish

Snohomish Junior High, Snohomish

Snohomish Senior High School, Snohomish

Snoqualmie Middle School, Snoqualmie

Soap Lake Junior-Senior High, Soap Lake

South Bend Junior-Senior High, South Bend

South Kitsap High School, Port orchard

South Shore Middle School, Seattle

South Whidbey High School, Langley

Spanaway Junior High, Tacoma

Spanaway Lake High School, Spanaway

Special Education Center, Clarkston

Spokane Valley Alternative High, Spokane

Sprague High School, Sprague

Springdale Middle School, Springdale

st. John/Endicott High, st. John 
121

189

189

123

121

NC

114

112

121

189

189

121

121

105

105

121

121

121

121

121

101

113

113

121

105
Stadium Senior High school, Tacoma

Stanwood High School, Stanwood

Stanwood Middle School, stanwood

Starbuck Junior High, Starbuck

Steilacoom High School, Steilacoom

Sterling Middle School, E. Wenatchee

Stevens Middle School, Port Angeles

Stevenson High, Stevenson

Stewart Middle School, Tacoma

Sultan Middle school, sultan

Sultan Junior-Senior High, Sultan

Summit $\mathrm{K}-12$, Seattle

Sumner Junior High, Sumner

Sunnyside Junior High, Sunnyside

Sunnyside Senior High School, Sunnyside

Surprise Lake Middle School, Milton

Sylvester Middle School, Seattle

Tahoma Junior High School, Maple Valley

Tahoma Senior High School, Maple Valley

TAPP Program, seattle

Tekoa High School, Tekoa

Tenino Middle School, Tenino

Tenino High School, Tenino

Thomas Jefferson High School, Auburn

Thorp High School, Thorp 


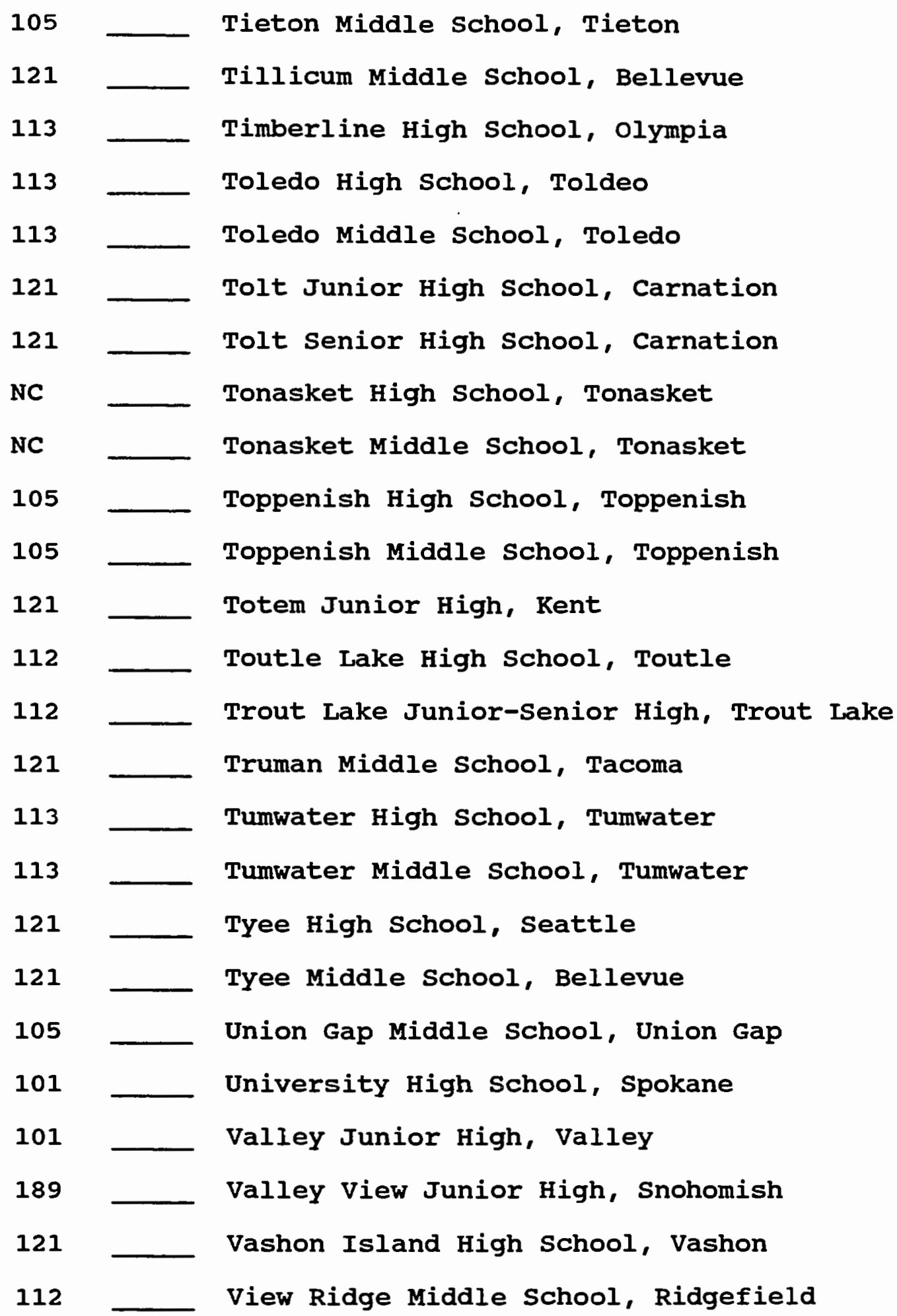


Vista Middle School, Ferndale

W. F. West High School, Chehalis Wahkiakum High School, Cathlamet

Wahluke High School, Mattawa

Waitsburg High School, Waitsburg

123 Walla Walla High School, Walla Walla

Walter Strom Junior High, Roslyn

Wapato Junior High, Wapato

105

Wapato Senior High School, Wapato

NC

Warden High School, Warden

NC

Warden Middle School, Warden

121

Washington High School, Tacoma

113

Washington Middle School, olympia

121

Washington Middle School, Seattle

105

Washington Middle School, Yakima

112

Washougal High School, Washougal

101

Washtucna High School, Washtucna

NC

Waterville Junior-Senior High, Waterville

113

Weatherwax High School, Aberdeen

101

Wellpinit High School, Wellpinit

NC

Wenatchee High School, Wenatchee

121

West Seattle High School, Seattle

101

West Valley High School, Spokane

105

West Valley High School, Yakima

105

West Valley Junior High, Yakima 


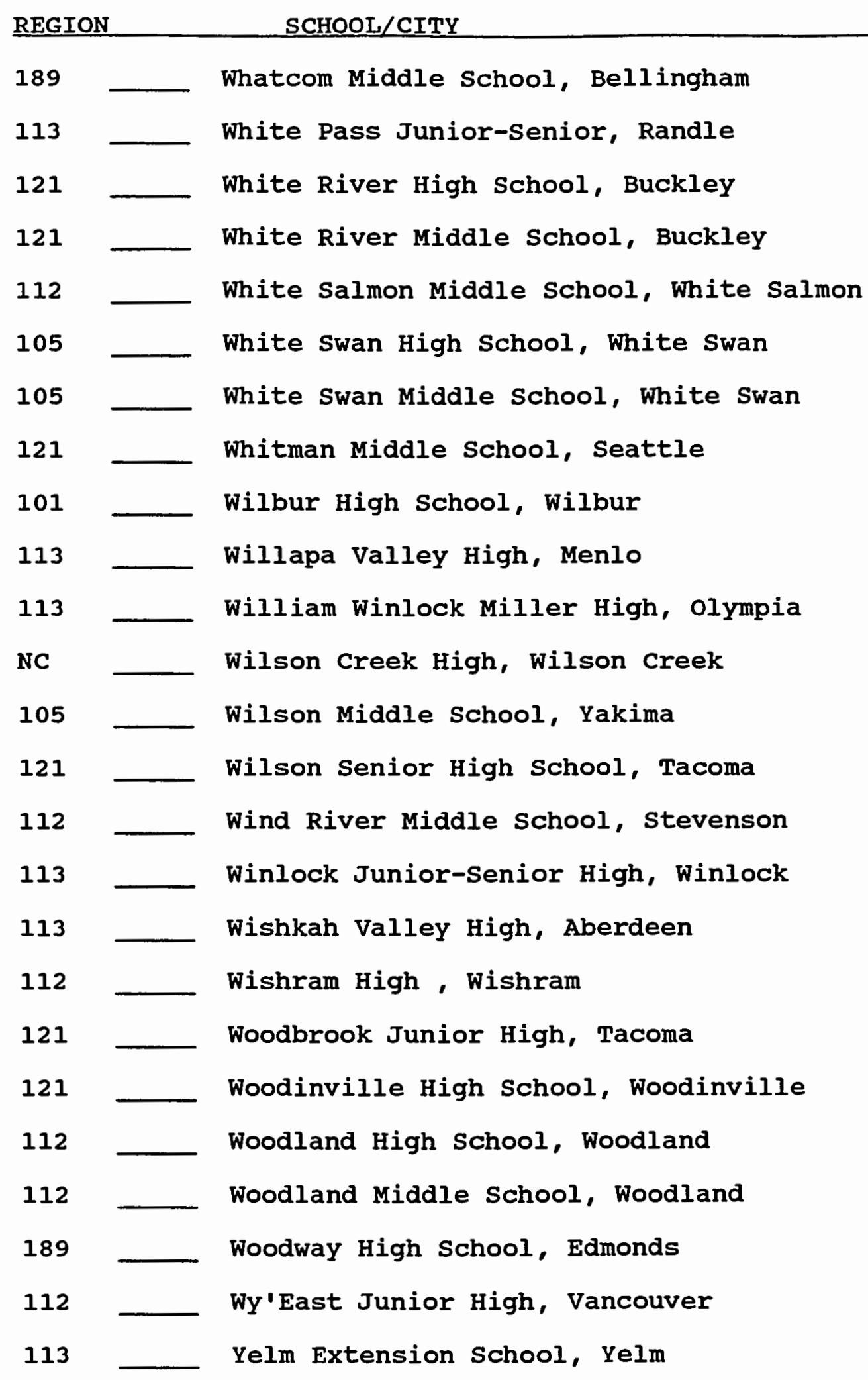


113

Yelm High School, Yelm

113 Yelm Middle School, Yelm

112 Zellerbach Middle School, Camas

105 Zillah Middle School, Zillah

105 Zillah High School, Zillah 


\section{APPENDIX $1-\mathrm{H}$}

TELEPHONE INTERVIEW QUESTIONS AS A FOLLOW UP TO THE SURVEY OF DRUG EDUCATION PROGRAMS IN WASHINGTON STATE'S SECONDARY PUBLIC SCHOOLS

FOR SCHOOL YEAR 1987-88 
APPENDIX $1-\mathrm{H}$

TELEPHONE INTERVIEW QUESTIONS AS A FOLLOW UP TO THE

SURVEY OF DRUG EDUCATION PROGRAMS IN WASHINGTON STATE SECONDARY PUBLIC SCHOOLS FOR SCHOOL YEAR 1987-88

CASE SCHOOL IDENTIFICATION NUMBER

SCHOOL NAME

SCHOOL ADDRESS

SCHOOL DISTRICT

CONTACT PERSON

POSITION

DATE

TIME

INTERVIEWER

\begin{tabular}{|c|c|}
\hline QUESTION & RESPONSE \\
\hline $\begin{array}{l}\text { 1. Confirm school's configur- } \\
\text { ation (middle school, junior } \\
\text { high school, high school, etc. }\end{array}$ & \\
\hline $\begin{array}{l}\text { 2. Confirm approximate student } \\
\text { enrollment at each grade level. }\end{array}$ & \\
\hline $\begin{array}{l}\text { 3. For those schools indicating } \\
\text { formal drug education programs: } \\
\text { Please describe your formal drug } \\
\text { education program at each grade } \\
\text { level }\end{array}$ & \\
\hline $\begin{array}{l}\text { 4. For those schools indicating } \\
\text { that they have an established } \\
\text { program for identifying students: } \\
\text { How does your school go about } \\
\text { identifying students who are } \\
\text { harmfully involved with alcohol } \\
\text { and/or other drugs? }\end{array}$ & \\
\hline $\begin{array}{l}\text { 5. Confirm how long this } \\
\text { program has been in place. }\end{array}$ & \\
\hline $\begin{array}{l}\text { 6. What kind of formal training } \\
\text { is given to various staff members } \\
\text { relative to identifying students } \\
\text { who are harmfully involved with } \\
\text { alcohol and/or other drugs. }\end{array}$ & \\
\hline
\end{tabular}




\begin{tabular}{|c|c|}
\hline QUESTION & RESPONSE \\
\hline $\begin{array}{l}\text { 7. For those schools indicating } \\
\text { that they have a student peer } \\
\text { assistance program: please } \\
\text { describe the student peer } \\
\text { assistance program that you have } \\
\text { at your school. }\end{array}$ & \\
\hline $\begin{array}{l}\text { 8. For those schools that } \\
\text { indicate that they provide for } \\
\text { assessments to determine whether } \\
\text { or not students are harmfully } \\
\text { involved with alcohol and/or } \\
\text { other drugs: please describe } \\
\text { your assessment program for } \\
\text { determining whether or not } \\
\text { students are harmfully involved } \\
\text { with alcohol and/or other drugs. }\end{array}$ & \\
\hline $\begin{array}{l}\text { 9. For those schools } \\
\text { indicating that they have a } \\
\text { formal student referral process } \\
\text { for students who have been } \\
\text { identified and assessed as } \\
\text { being harmfully involved with } \\
\text { alcohol and/or other drugs: } \\
\text { please describe your formal } \\
\text { referral process for students } \\
\text { who have been identified as } \\
\text { being harmfully involved with } \\
\text { alcohol and/or other drugs. }\end{array}$ & \\
\hline $\begin{array}{l}\text { 10. For those schools } \\
\text { indicating that they have an } \\
\text { established reentry program for } \\
\text { students returning to their } \\
\text { school after having received } \\
\text { counseling or treatment for } \\
\text { alcohol and/or other drug } \\
\text { abuse: Please describe your } \\
\text { school's reentry program for } \\
\text { students returning to your } \\
\text { school after having received } \\
\text { counseling or treatment for } \\
\text { alcohol and/or other drugs. }\end{array}$ & \\
\hline
\end{tabular}




\begin{tabular}{|c|c|}
\hline QUESTION & RESPONSE \\
\hline $\begin{array}{l}\text { 11. Confirm the estimated number } \\
\text { of students at each grade level } \\
\text { during the } 1987-88 \text { school year } \\
\text { that were identified as being } \\
\text { harmfully involved with alcohol } \\
\text { and/or other drugs. }\end{array}$ & \\
\hline $\begin{array}{l}\text { 12. Please describe how these } \\
\text { students were identified as } \\
\text { being harmfully involved with } \\
\text { alcohol and/or other drugs. }\end{array}$ & \\
\hline $\begin{array}{l}\text { 13. What kind of documentation } \\
\text { do you have that would } \\
\text { substantiate the estimated } \\
\text { number of students at each } \\
\text { grade that were identified as } \\
\text { being harmfully involved with } \\
\text { alcohol and/or other drugs? }\end{array}$ & \\
\hline $\begin{array}{l}\text { 14. Confirm the estimated } \\
\text { number of students at each } \\
\text { grade level during the } 1987-88 \\
\text { school year that were referred } \\
\text { to special services. }\end{array}$ & \\
\hline $\begin{array}{l}\text { 15. Please describe how these } \\
\text { students were referred to } \\
\text { special services. }\end{array}$ & \\
\hline $\begin{array}{l}\text { 16. What kind of documentation } \\
\text { do you have that would } \\
\text { substantiate the estimated } \\
\text { number of students at each } \\
\text { grade level that were referred } \\
\text { to special services? }\end{array}$ & \\
\hline $\begin{array}{l}\text { 17. Confirm the estimated } \\
\text { number of students at each } \\
\text { grade level during the 1987-88 } \\
\text { school year that were referred } \\
\text { to special services outside of } \\
\text { the school. }\end{array}$ & \\
\hline
\end{tabular}




\begin{tabular}{|l|l|}
\hline \multicolumn{1}{|c|}{ QUESTION } & RESPONSE \\
\hline $\begin{array}{l}\text { 18. Please describe how these } \\
\text { students were referred to } \\
\text { special services outside of } \\
\text { the school. }\end{array}$ & \\
\hline $\begin{array}{l}\text { 19. What kind of documentation } \\
\text { do you have that would } \\
\text { substantiate the estimated } \\
\text { number of students at each } \\
\text { grade that were referred to } \\
\text { special services outside of } \\
\text { the school? }\end{array}$ \\
\hline $\begin{array}{l}\text { 20. Please confirm the number } \\
\text { of students at each grade level } \\
\text { during the 1987-88 school year } \\
\text { that were subsequently referred } \\
\text { to formal assessment for } \\
\text { chemical dependency. }\end{array}$ \\
\hline $\begin{array}{l}\text { 21. What kind of documentation } \\
\text { do you have that would } \\
\text { substantiate the number of } \\
\text { students at each grade that } \\
\text { were subsequently referred to } \\
\text { formal assessment for chemical } \\
\text { dependency? }\end{array}$ \\
\hline $\begin{array}{l}\text { 22. Please confirm the number } \\
\text { of students at each grade level } \\
\text { during the 1987-88 school year } \\
\text { that received formal treatment } \\
\text { for chemical dependency. }\end{array}$ \\
\hline $\begin{array}{l}23 \text { what kind of documentation } \\
\text { do you have that would } \\
\text { substantiate the number of } \\
\text { students at each grade that } \\
\text { received formal treatment for } \\
\text { chemical dependency? }\end{array}$ \\
\end{tabular}


DETERMINATION :

1. Are this school's survey data accurate and consistent with the intention of this study:

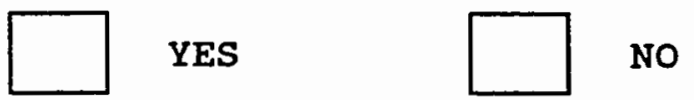

Explain:

2. Should this school be placed into the miltiple-case study population?

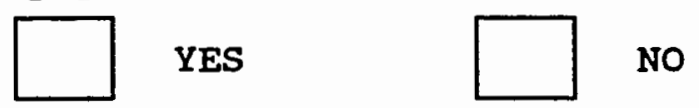

Explain: 


\author{
APPENDIX 1-I \\ LETTER RECONFIRMING PERMISSION FROM BUILDING \\ PRINCIPALS FOR PARTICIPATION \\ IN PILOT STUDY
}


APPENDIX 1-I

November 27,1988

F1
F2
F53
-F4

Dear `F5^:

Thank you again for allowing 'F2' to participate in the multiple-case study of drug education intervention programs in washington state public high schools currently being conducted by Educational service District 114 for Washington's Bureau of Alcohol and Substance Abuse. 'F2' will be one of twelve public high schools in washington state that participates in the onsite visitation phase of this study. Information collected through the site visitations, along with survey data collected from more than 500 secondary schools. will assist in the development of a comprehensive report that describes the status of drug education intervention programs in Washington State's public high schools as of June, 1988 .

I have enclosed copies of the various interview questions to be asked during the site visitation. As you can see, I will need to meet for approximately forty-five minutes with your administrative staff (together), your counseling staff (together), members of your classified support staff and teaching staff (together) and members of your student body (together). Only those questions appearing on the interview form will be asked. You or a member of your staff would be welcome to sit in during the student interviews.

In addition to the interviews, it would be very helpful if someone on your staff could arrange for me to review any documents you might have regarding your school's drug education curriculum, alcohol and drug policies, alcohol and drug procedures and any other documents that you think may be of interest and value to this study. 
${ }^{\wedge} \mathrm{F} 1{ }^{\wedge}$

November 27,1988

Page Two

Your participation in this phase of our statewide study is greatly appreciated. Information collected through this study will serve to benefit educational administrators, teachers, students and government officials alike as we work to improve drug education in Washington state.

Thank you again for your participation, and please call me if you have any questions regarding these materials. I will be calling you in the near future to reconfirm our appointment.

sincerely,

Todd Herberg, Administrative Assistant

for Instructional Services

Enclosure

$\mathbf{T H}: \mathbf{n l C}$ 
APPENDIX 1-J

INITIAL ONSITE INTERVIEW FORMS

(PILOT STUDY) 
APPENDIX 1-J

ADMINISTRATION INTERVIEW FORM

CASE SCHOOL IDENTIFICATION NUMBER

DATE

INTERVIEWER

\begin{tabular}{|c|c|}
\hline QUESTION & RESPONSE \\
\hline $\begin{array}{l}\text { 1. What kind of formal drug } \\
\text { education instruction programs } \\
\text { exist in your school? }\end{array}$ & \\
\hline $\begin{array}{l}\text { 2. What kind of an established } \\
\text { program does your school have } \\
\text { for identifying students who } \\
\text { are harmfully involved with } \\
\text { alcohol and/or other drugs? }\end{array}$ & \\
\hline $\begin{array}{l}\text { 3. What building staff members } \\
\text { in your school participate in } \\
\text { the identification of students } \\
\text { who are harmfully involved with } \\
\text { alcohol and/or other drugs? }\end{array}$ & \\
\hline $\begin{array}{l}\text { 4. What kind of formal train- } \\
\text { ing do individuals receive in } \\
\text { identification strategies for } \\
\text { students who are harmfully } \\
\text { involved with alcohol and/or } \\
\text { other drugs? }\end{array}$ & \\
\hline $\begin{array}{l}\text { 5. What building staff in your } \\
\text { school are involved in } \\
\text { referring students who are } \\
\text { harmfully involved with alcohol } \\
\text { and/or other drugs to some kind } \\
\text { of special service that meets } \\
\text { their needs? }\end{array}$ & \\
\hline $\begin{array}{l}\text { 6. What kind of formal train- } \\
\text { ing do individuals receive in } \\
\text { referral strategies for } \\
\text { students who are harmfully } \\
\text { involved with alcohol and/or } \\
\text { and/or other drugs? }\end{array}$ & \\
\hline $\begin{array}{l}\text { 7. Does your school have a } \\
\text { student peer assistance program } \\
\text { that includes activities } \\
\text { related to substance abuse } \\
\text { among students? }\end{array}$ & \\
\hline
\end{tabular}




\begin{tabular}{|c|c|}
\hline QUESTION & RESPONSE \\
\hline $\begin{array}{l}\text { 8. Does your school have an } \\
\text { established system that enables } \\
\text { a concerned student to refer } \\
\text { another student to school staff } \\
\text { for possible problems related } \\
\text { to alcohol and drug abuse? }\end{array}$ & \\
\hline $\begin{array}{l}\text { 9. Does your school have an } \\
\text { established process for helping } \\
\text { students obtain formal } \\
\text { assessment relative to alcohol } \\
\text { and/or other drug abuse and } \\
\text { chemical dependency? }\end{array}$ & \\
\hline $\begin{array}{l}\text { 10. Does your school have an } \\
\text { established reentry program for } \\
\text { students returning to your } \\
\text { school after having received } \\
\text { counseling or treatment for } \\
\text { alcohol and/or other drug } \\
\text { abuse? }\end{array}$ & \\
\hline $\begin{array}{l}\text { 11. During the } 1987-88 \text { school } \\
\text { year did your school have a } \\
\text { formal written policy regarding } \\
\text { student alcohol and/or other } \\
\text { drug abuse? }\end{array}$ & \\
\hline $\begin{array}{l}\text { 12. Approximately how many of } \\
\text { your school's students at each } \\
\text { grade level during the 1987-88 } \\
\text { were identified as being } \\
\text { harmfully involved with alcohol } \\
\text { and/or other drugs? }\end{array}$ & \\
\hline $\begin{array}{l}\text { 13. Of your school's students } \\
\text { identified as being harmfully } \\
\text { involved with alcohol and/or } \\
\text { other drugs during the 1987-88 } \\
\text { school year, how many of these } \\
\text { students were rererred to } \\
\text { special services within the } \\
\text { school such as counseling? }\end{array}$ & \\
\hline
\end{tabular}




\begin{tabular}{|c|c|}
\hline QUESTION & RESPONSE \\
\hline $\begin{array}{l}\text { 14. of your school's students } \\
\text { identified as being harmfully } \\
\text { involved with alcohol and/or } \\
\text { other drugs during the 1987-88 } \\
\text { school year, how many of these } \\
\text { students were referred to } \\
\text { special services outside of } \\
\text { the school such as counseling } \\
\text { and/or formal assessment? }\end{array}$ & \\
\hline $\begin{array}{l}\text { 15. How many of your school's } \\
\text { students at each grade level } \\
\text { during the } 1987-88 \text { school year } \\
\text { received formal treatment for } \\
\text { chemical dependency? }\end{array}$ & \\
\hline $\begin{array}{l}\text { 16. Why is your school's drug } \\
\text { education intervention program } \\
\text { as large and extensive as it } \\
\text { is? }\end{array}$ & \\
\hline $\begin{array}{l}\text { 17. How does your school's drug } \\
\text { education intervention program } \\
\text { utilize outside agencies and } \\
\text { organizations? }\end{array}$ & \\
\hline $\begin{array}{l}\text { 18. What is the most successful } \\
\text { aspects of your school's drug } \\
\text { education program? }\end{array}$ & \\
\hline $\begin{array}{l}\text { 19. How can your school's drug } \\
\text { education program be improved? }\end{array}$ & \\
\hline $\begin{array}{l}\text { 20. How does the central office } \\
\text { support your school's drug } \\
\text { education program? }\end{array}$ & \\
\hline $\begin{array}{l}\text { 21. How does the community/ } \\
\text { parental support your school's } \\
\text { drug education program? }\end{array}$ & \\
\hline $\begin{array}{l}\text { 22. Who is responsible for } \\
\text { managing and/or administrating } \\
\text { your school's drug education } \\
\text { program? }\end{array}$ & \\
\hline
\end{tabular}


COUNSELORS INTERVIEW FORM

CASE SCHOOL IDENTIFICATION NUMBER

DATE

INTERVIEWER

\begin{tabular}{|c|c|}
\hline QUESTION & RESPONSE \\
\hline $\begin{array}{l}\text { 1. What kind of formal drug } \\
\text { education instruction programs } \\
\text { exist in your school? }\end{array}$ & \\
\hline $\begin{array}{l}\text { 2. What kind of an established } \\
\text { program does your school have } \\
\text { for identifying students who } \\
\text { are harmfully involved with } \\
\text { alcohol and/or other drugs? }\end{array}$ & \\
\hline $\begin{array}{l}\text { 3. What building staff members } \\
\text { in your school participate in } \\
\text { the identification of students } \\
\text { who are harmfully involved with } \\
\text { alcohol and/or other drugs? }\end{array}$ & \\
\hline $\begin{array}{l}\text { 4. What kind of formal train- } \\
\text { ing do individuals receive in } \\
\text { identification strategies for } \\
\text { students who are harmfully } \\
\text { involved with alcohol and/or } \\
\text { other drugs? }\end{array}$ & \\
\hline $\begin{array}{l}\text { 5. What building staff in your } \\
\text { school are involved in } \\
\text { referring students who are } \\
\text { harmfully involved with alcohol } \\
\text { and/or other drugs to some kind } \\
\text { of special service that meets } \\
\text { their needs? }\end{array}$ & \\
\hline $\begin{array}{l}\text { 6. What kind of formal train- } \\
\text { ing do individuals receive in } \\
\text { referral strategies for } \\
\text { students who are harmfully } \\
\text { involved with alcohol and/or } \\
\text { and/or other drugs? }\end{array}$ & \\
\hline $\begin{array}{l}\text { 7. Does your school have a } \\
\text { student peer assistance program } \\
\text { that includes activities } \\
\text { related to substance abuse } \\
\text { among students? }\end{array}$ & \\
\hline
\end{tabular}




\begin{tabular}{|c|c|}
\hline QUESTION & RESPONSE \\
\hline $\begin{array}{l}\text { 8. Does your school have an } \\
\text { established system that enables } \\
\text { a concerned student to refer } \\
\text { another student to school staff } \\
\text { for possible problems related } \\
\text { to alcohol and drug abuse? }\end{array}$ & \\
\hline $\begin{array}{l}\text { 9. Does your school have an } \\
\text { established process for helping } \\
\text { students obtain formal } \\
\text { assessment relative to alcohol } \\
\text { and/or other drug abuse and } \\
\text { chemical dependency? }\end{array}$ & \\
\hline $\begin{array}{l}\text { 10. Does your school have an } \\
\text { established reentry program for } \\
\text { students returning to your } \\
\text { school after having received } \\
\text { counseling or treatment for } \\
\text { alcohol and/or other drug } \\
\text { abuse? }\end{array}$ & \\
\hline $\begin{array}{l}\text { 11. During the } 1987-88 \text { school } \\
\text { year did your school have a } \\
\text { formal written policy regarding } \\
\text { student alcohol and/or other } \\
\text { drug abuse? }\end{array}$ & \\
\hline $\begin{array}{l}\text { 12. Approximately how many of } \\
\text { your school's students at each } \\
\text { grade level during the 1987-88 } \\
\text { were identified as being } \\
\text { harmfully involved with alcohol } \\
\text { and/or other drugs? }\end{array}$ & \\
\hline $\begin{array}{l}\text { 13. Of your school's students } \\
\text { identified as being harmfully } \\
\text { involved with alcohol and/or } \\
\text { other drugs during the 1987-88 } \\
\text { school year, how many of these } \\
\text { students were referred to } \\
\text { special services within the } \\
\text { school such as counseling? }\end{array}$ & \\
\hline
\end{tabular}




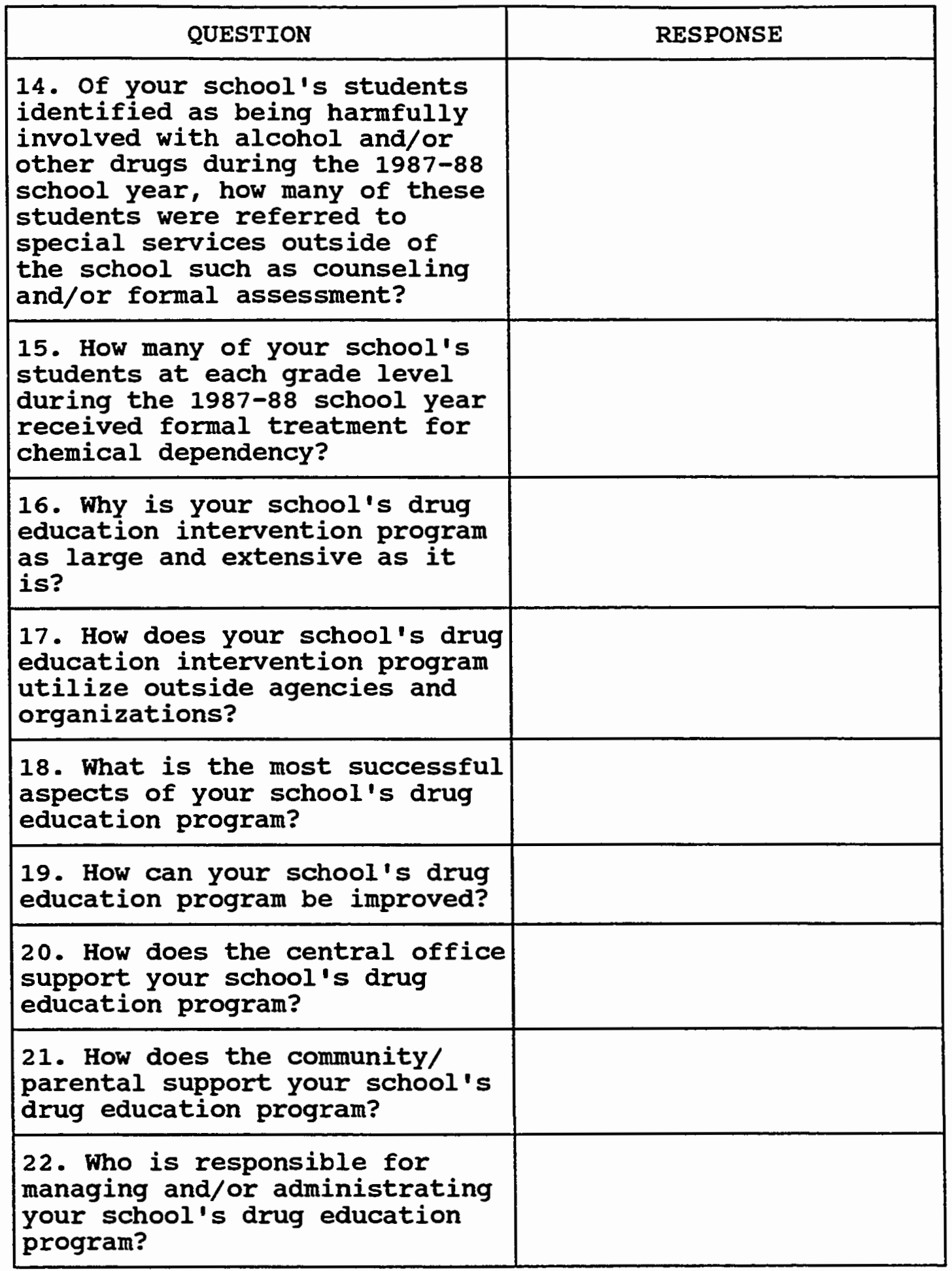


TEACHER INTERVIEW FORM

CASE SCHOOL IDENTIFICATION NUMBER

DATE

INTERVIEWER

\begin{tabular}{|c|c|}
\hline QUESTION & RESPONSE \\
\hline $\begin{array}{l}\text { 1. What kind of formal drug } \\
\text { education instruction programs } \\
\text { exist in your school? }\end{array}$ & \\
\hline $\begin{array}{l}\text { 2. What kind of an established } \\
\text { program does your school have } \\
\text { for identifying students who } \\
\text { are harmfully involved with } \\
\text { alcohol and/or other drugs? }\end{array}$ & \\
\hline $\begin{array}{l}\text { 3. What building staff members } \\
\text { in your school participate in } \\
\text { the identification of students } \\
\text { who are harmfully involved with } \\
\text { alcohol and/or other drugs? }\end{array}$ & \\
\hline $\begin{array}{l}\text { 4. What kind of formal train- } \\
\text { ing do individuals receive in } \\
\text { identification strategies for } \\
\text { students who are harmfully } \\
\text { involved with alcohol and/or } \\
\text { other drugs? }\end{array}$ & \\
\hline $\begin{array}{l}\text { 5. What building staff in your } \\
\text { school are involved in } \\
\text { referring students who are } \\
\text { harmfully involved with alcohol } \\
\text { and/or other drugs to some kind } \\
\text { of special service that meets } \\
\text { their needs? }\end{array}$ & \\
\hline $\begin{array}{l}\text { 6. What kind of formal train- } \\
\text { ing do individuals receive in } \\
\text { referral strategies for } \\
\text { students who are harmfully } \\
\text { involved with alcohol and/or } \\
\text { and/or other drugs? }\end{array}$ & \\
\hline $\begin{array}{l}\text { 7. Does your school have a } \\
\text { student peer assistance program } \\
\text { that includes activities } \\
\text { related to substance abuse } \\
\text { among students? }\end{array}$ & \\
\hline
\end{tabular}




\begin{tabular}{|c|c|}
\hline QUESTION & RESPONSE \\
\hline $\begin{array}{l}\text { 8. Does your school have an } \\
\text { established system that enables } \\
\text { a concerned student to refer } \\
\text { another student to school staff } \\
\text { for possible problems related } \\
\text { to alcohol and drug abuse? }\end{array}$ & \\
\hline $\begin{array}{l}\text { 9. Does your school have an } \\
\text { established process for helping } \\
\text { students obtain formal } \\
\text { assessment relative to alcohol } \\
\text { and/or other drug abuse and } \\
\text { chemical dependency? }\end{array}$ & \\
\hline $\begin{array}{l}\text { 10. Does your school have an } \\
\text { established reentry program for } \\
\text { students returning to your } \\
\text { school after having received } \\
\text { counseling or treatment for } \\
\text { alcohol and/or other drug } \\
\text { abuse? }\end{array}$ & \\
\hline $\begin{array}{l}\text { 11. During the } 1987-88 \text { school } \\
\text { year did your school have a } \\
\text { formal written policy regarding } \\
\text { student alcohol and/or other } \\
\text { drug abuse? }\end{array}$ & \\
\hline $\begin{array}{l}\text { 12. Approximately how many of } \\
\text { your school's students at each } \\
\text { grade level during the 1987-88 } \\
\text { were identified as being } \\
\text { harmfully involved with alcohol } \\
\text { and/or other drugs? }\end{array}$ & \\
\hline $\begin{array}{l}\text { 13. Of your school's students } \\
\text { identified as being harmfully } \\
\text { involved with alcohol and/or } \\
\text { other drugs during the 1987-88 } \\
\text { school year, how many of these } \\
\text { students were referred to } \\
\text { special services within the } \\
\text { school such as counseling? }\end{array}$ & \\
\hline
\end{tabular}




\begin{tabular}{|c|c|}
\hline QUESTION & RESPONSE \\
\hline $\begin{array}{l}\text { 14. Of your school's students } \\
\text { identified as being harmfully } \\
\text { involved with alcohol and/or } \\
\text { other drugs during the 1987-88 } \\
\text { school year, how many of these } \\
\text { students were referred to } \\
\text { special services outside of } \\
\text { the school such as counseling } \\
\text { and/or formal assessment? }\end{array}$ & \\
\hline $\begin{array}{l}\text { 15. How many of your school's } \\
\text { students at each grade level } \\
\text { during the } 1987-88 \text { school year } \\
\text { received formal treatment for } \\
\text { chemical dependency? }\end{array}$ & \\
\hline $\begin{array}{l}\text { 16. Why is your school's drug } \\
\text { education intervention program } \\
\text { as large and extensive as it } \\
\text { is? }\end{array}$ & \\
\hline $\begin{array}{l}\text { 17. How does your school's drug } \\
\text { education intervention program } \\
\text { utilize outside agencies and } \\
\text { organizations? }\end{array}$ & \\
\hline $\begin{array}{l}\text { 18. What is the most successful } \\
\text { aspects of your school's drug } \\
\text { education program? }\end{array}$ & \\
\hline $\begin{array}{l}\text { 19. How can your school's drug } \\
\text { education program be improved? }\end{array}$ & \\
\hline $\begin{array}{l}\text { 20. How does the central office } \\
\text { support your school's drug } \\
\text { education program? }\end{array}$ & \\
\hline $\begin{array}{l}\text { 21. How does the community/ } \\
\text { parental support your school's } \\
\text { drug education program? }\end{array}$ & \\
\hline $\begin{array}{l}\text { 22. Who is responsible for } \\
\text { managing and/or administrating } \\
\text { your school's drug education } \\
\text { program? }\end{array}$ & \\
\hline
\end{tabular}


CLASSIFIED SUPPORT STAFF INTERVIEW FORM

CASE SCHOOL IDENTIFICATION NUMBER

DATE INTERVIEWER

\begin{tabular}{|c|c|}
\hline QUESTION & RESPONSE \\
\hline $\begin{array}{l}\text { 1. What kind of formal drug } \\
\text { education instruction programs } \\
\text { exist in your school? }\end{array}$ & \\
\hline $\begin{array}{l}\text { 2. What kind of an established } \\
\text { program does your school have } \\
\text { for identifying students who } \\
\text { are harmfully involved with } \\
\text { alcohol and/or other drugs? }\end{array}$ & \\
\hline $\begin{array}{l}\text { 3. What building staff members } \\
\text { in your school participate in } \\
\text { the identification of students } \\
\text { who are harmfully involved with } \\
\text { alcohol and/or other drugs? }\end{array}$ & \\
\hline $\begin{array}{l}\text { 4. What kind of formal train- } \\
\text { ing do individuals receive in } \\
\text { identification strategies for } \\
\text { students who are harmfully } \\
\text { involved with alcohol and/or } \\
\text { other drugs? }\end{array}$ & \\
\hline $\begin{array}{l}\text { 5. What building staff in your } \\
\text { school are involved in } \\
\text { referring students who are } \\
\text { harmfully involved with alcohol } \\
\text { and/or other drugs to some kind } \\
\text { of special service that meets } \\
\text { their needs? }\end{array}$ & \\
\hline $\begin{array}{l}\text { 6. What kind of formal train- } \\
\text { ing do individuals receive in } \\
\text { referral strategies for } \\
\text { students who are harmfully } \\
\text { involved with alcohol and/or } \\
\text { and/or other drugs? }\end{array}$ & \\
\hline $\begin{array}{l}\text { 7. Does your school have a } \\
\text { student peer assistance program } \\
\text { that includes activities } \\
\text { related to substance abuse } \\
\text { among students? }\end{array}$ & \\
\hline
\end{tabular}




\begin{tabular}{|c|c|}
\hline QUESTION & RESPONSE \\
\hline $\begin{array}{l}\text { 8. Does your school have an } \\
\text { established system that enables } \\
\text { a concerned student to refer } \\
\text { another student to school staff } \\
\text { for possible problems related } \\
\text { to alcohol and drug abuse? }\end{array}$ & \\
\hline $\begin{array}{l}\text { 9. Does your school have an } \\
\text { established process for helping } \\
\text { students obtain formal } \\
\text { assessment relative to alcohol } \\
\text { and/or other drug abuse and } \\
\text { chemical dependency? }\end{array}$ & \\
\hline $\begin{array}{l}\text { 10. Does your school have an } \\
\text { established reentry program for } \\
\text { students returning to your } \\
\text { school after having received } \\
\text { counseling or treatment for } \\
\text { alcohol and/or other drug } \\
\text { abuse? }\end{array}$ & \\
\hline $\begin{array}{l}\text { 11. During the } 1987-88 \text { school } \\
\text { year did your school have a } \\
\text { formal written policy regarding } \\
\text { student alcohol and/or other } \\
\text { drug abuse? }\end{array}$ & \\
\hline $\begin{array}{l}\text { 12. Approximately how many of } \\
\text { your school's students at each } \\
\text { grade level during the 1987-88 } \\
\text { were identified as being } \\
\text { harmfully involved with alcohol } \\
\text { and/or other drugs? }\end{array}$ & \\
\hline $\begin{array}{l}\text { 13. Of your school's students } \\
\text { identified as being harmfully } \\
\text { involved with alcohol and/or } \\
\text { other drugs during the 1987-88 } \\
\text { school year, how many of these } \\
\text { students were referred to } \\
\text { special services within the } \\
\text { school such as counseling? }\end{array}$ & \\
\hline
\end{tabular}




\begin{tabular}{|c|c|}
\hline QUESTION & RESPONSE \\
\hline $\begin{array}{l}\text { 14. Of your school's students } \\
\text { identified as being harmfully } \\
\text { involved with alcohol and/or } \\
\text { other drugs during the } 1987-88 \\
\text { school year, how many of these } \\
\text { students were referred to } \\
\text { special services outside of } \\
\text { the school such as counseling } \\
\text { and/or formal assessment? }\end{array}$ & \\
\hline $\begin{array}{l}\text { 15. How many of your school's } \\
\text { students at each grade level } \\
\text { during the 1987-88 school year } \\
\text { received formal treatment for } \\
\text { chemical dependency? }\end{array}$ & \\
\hline $\begin{array}{l}\text { 16. Why is your school's drug } \\
\text { education intervention program } \\
\text { as large and extensive as it } \\
\text { is? }\end{array}$ & \\
\hline $\begin{array}{l}\text { 17. How does your school's drug } \\
\text { education intervention program } \\
\text { utilize outside agencies and } \\
\text { organizations? }\end{array}$ & \\
\hline $\begin{array}{l}\text { 18. What is the most successful } \\
\text { aspects of your school's drug } \\
\text { education program? }\end{array}$ & \\
\hline $\begin{array}{l}\text { 19. How can your school's drug } \\
\text { education program be improved? }\end{array}$ & \\
\hline $\begin{array}{l}\text { 20. How does the central office } \\
\text { support your school's drug } \\
\text { education program? }\end{array}$ & \\
\hline $\begin{array}{l}\text { 21. How does the community/ } \\
\text { parental support your school's } \\
\text { drug education program? }\end{array}$ & \\
\hline $\begin{array}{l}\text { 22. Who is responsible for } \\
\text { managing and/or administrating } \\
\text { your school's drug education } \\
\text { program? }\end{array}$ & \\
\hline
\end{tabular}


STUDENT INTERVIEW FORM

CASE SCHOOL IDENTIFICATION NUMBER

DATE INTERVIEWER

\begin{tabular}{|c|c|}
\hline QUESTION & RESPONSE \\
\hline $\begin{array}{l}\text { 1. At which grades do students } \\
\text { receive formal instruction in } \\
\text { drug education? }\end{array}$ & \\
\hline $\begin{array}{l}\text { 2. Please describe what kind } \\
\text { of drug education instruction } \\
\text { students receive at each grade } \\
\text { level. }\end{array}$ & \\
\hline $\begin{array}{l}\text { 3. What would you do if a } \\
\text { close student friend of yours } \\
\text { was using drugs and you wanted } \\
\text { to get that friend some help? }\end{array}$ & \\
\hline $\begin{array}{l}\text { 4. Does your school operate } \\
\text { any kind of support group for } \\
\text { students who have received } \\
\text { treatment for chemical } \\
\text { dependency and are now } \\
\text { returning to school again? }\end{array}$ & \\
\hline $\begin{array}{l}\text { 5. Who would a student go to } \\
\text { if he/she wanted to get help } \\
\text { for themselves regarding their } \\
\text { own abuse of alcohol and/or } \\
\text { other drugs? }\end{array}$ & \\
\hline $\begin{array}{l}\text { 6. Does your school have an } \\
\text { established policy (rules and } \\
\text { regulations) regarding student } \\
\text { use of alcohol and/or other } \\
\text { drugs? }\end{array}$ & \\
\hline $\begin{array}{l}\text { 7. What do you think your } \\
\text { school could do to improve its } \\
\text { drug education program? }\end{array}$ & \\
\hline
\end{tabular}




\section{APPENDIX 1-K}

LETTER REQUESTING PERMISSION FROM BUIIDING PRINCIPALS FOR ONSITE VISITATIONS 
January 21, 1989

\author{
APPENDIX $1-K$
}

${ }^{\wedge} \mathrm{F} 1{ }^{\wedge}$

${ }^{\wedge} \mathrm{F} 2{ }^{\wedge}$

${ }^{\wedge} \mathrm{F} 3{ }^{\wedge}$

${ }^{\wedge} \mathrm{F} 4^{\wedge}$

Dear 'F5^:

Thank you for allowing 'F2" to participate in the study of drug education intervention programs in washington state public high schools currently being conducted by Educational Service District 114 for Washington's Bureau of Alcohol and Substance Abuse. "F2" will be one of twelve public high schools in Washington state that participates in the onsite visitation phase of this study. Information collected through the site visitations, along with survey data collected from more than 500 secondary schools, will assist in the development of a comprehensive report that describes the status of drug education intervention programs in Washington state's public secondary schools.

Currently I am scheduled to arrive at your building around 'F7". Please let me know immediately if this time is no longer convenient.

I appreciate your assistance in organizing the four interview groups. The interviews groups again are:

1. Administrators and counselors (at least one representative from each of these groups).

2. Two or three teachers and one classified employee (if you have a teacher assigned to instruct a drug education class, please include them in this group; also, the preferred classified representative would be a school secretary).

3. Three or four students who are knowledgeable about your school's drug education services (specifically, this group should include students who have utilized assistance services such as those students who have received treatment for chemical dependency and are 
‘F1"

January 21, 1989

Page Two

now back in your school or students who have been otherwise identified as being harmfully involved with alcohol and/or other drugs).

4. Three or four students who have not been directly involved with your school's drug education programs (this group should include students who have not been identified as being harmfully involved with alcohol and/or other drugs).

The interviews for each of these groups should last between 30-40 minutes. Please arrange an interview schedule that spaces each of the groups 50-60 minutes apart. The groups don't have to be sequenced in any particular order. I also need you to arrange for an interview location large enough for four to five people where we can work without interruption.

I have enclosed copies of the staff and student interview questions to be asked during the site visitation. Please do not share these interview questions with the interview participants. I am providing them for your information only. You or a member of your staff would be welcome to sit in during the student interviews, although it has been my experience that students are much more willing to discuss the subjects when there is no staff observation.

Information collected through this study will serve to benefit educational administrators, teachers, students and government officials alike as we work to improve drug education in washington state. Thank you again for your participation, and please call me if you have any questions regarding the proposed arrangements or the enclosed materials.

Sincerely,

Todd Herberg, Administrative Assistant

for Instructional Services

Enclosure

$\mathrm{CC}:{ }^{\wedge} \mathrm{F} 8{ }^{-}$

TH: nlc 
APPENDIX $1-L$

FINAL ONSITE VISITATION INTERVIEW FORMS 
APPENDIX 1-L

INTERVIEW FORM FOR BUILDING ADMINISTRATORS

AND COUNSELORS

CASE SCHOOL IDENTIFICATION NUMBER

DATE

INTERVIEWER

\begin{tabular}{|c|c|}
\hline QUESTION & RESPONSE \\
\hline $\begin{array}{l}\text { 1. What kind of formal drug } \\
\text { education instruction } \\
\text { programs exist in your } \\
\text { school at each grade } \\
\text { level and what kind of } \\
\text { instruction do they } \\
\text { receive? }\end{array}$ & \\
\hline $\begin{array}{l}\text { 2. Please describe how your } \\
\text { school goes about } \\
\text { identifying students who } \\
\text { are harmfully involved } \\
\text { with alcohol and/or other } \\
\text { drugs? }\end{array}$ & \\
\hline $\begin{array}{l}\text { 3. What building staff } \\
\text { members in your school } \\
\text { participate in the } \\
\text { identification of students } \\
\text { who are harmfully involved } \\
\text { with alcohol and/or other } \\
\text { drugs, and what kind of } \\
\text { training have they } \\
\text { received? }\end{array}$ & \\
\hline $\begin{array}{l}\text { 4. What building staff in } \\
\text { your school are involved } \\
\text { in referring students who } \\
\text { are harmfully involved } \\
\text { with alcohol and/or other } \\
\text { drugs to some kind of } \\
\text { special service that meets } \\
\text { their needs, and what kind } \\
\text { of training have they } \\
\text { received? }\end{array}$ & \\
\hline
\end{tabular}




\begin{tabular}{|c|c|c|}
\hline \multicolumn{2}{|r|}{ QUESTION } & RESPONSE \\
\hline 5. & $\begin{array}{l}\text { Who are students referred } \\
\text { to if staff suspect that a } \\
\text { student is harmfully } \\
\text { involved with alcohol and/ } \\
\text { or other drugs? }\end{array}$ & \\
\hline 6. & $\begin{array}{l}\text { Who determines the } \\
\text { severity of a student's } \\
\text { problem, and whether or } \\
\text { not the student needs } \\
\text { special assistance? }\end{array}$ & \\
\hline 7 & $\begin{array}{l}\text { Please describe what, if } \\
\text { any, student peer } \\
\text { assistance program you } \\
\text { have that includes } \\
\text { activities related to } \\
\text { substance abuse among } \\
\text { students? }\end{array}$ & \\
\hline 8 & $\begin{array}{l}\text { How would a student refer } \\
\text { themselves or another } \\
\text { student to school staff } \\
\text { for possible problems } \\
\text { related to alcohol and } \\
\text { drug abuse? }\end{array}$ & \\
\hline
\end{tabular}




\begin{tabular}{|c|c|c|}
\hline & QUESTION & RESPONSE \\
\hline & $\begin{array}{l}\text { How are students } \\
\text { instructed on how to do } \\
\text { this? }\end{array}$ & \\
\hline 10. & $\begin{array}{l}\text { Does your school have an } \\
\text { established process for } \\
\text { helping students obtain } \\
\text { formal assessment relative } \\
\text { to alcohol and/or other } \\
\text { drug abuse and chemical } \\
\text { dependency? }\end{array}$ & \\
\hline 11. & If yes, please describe. & \\
\hline 12 & $\begin{array}{l}\text { Does your school have an } \\
\text { established reentry } \\
\text { program for students } \\
\text { returning to your school } \\
\text { after having received } \\
\text { counseling or treatment } \\
\text { for alcohol and/or other } \\
\text { drug abuse? }\end{array}$ & \\
\hline
\end{tabular}




\begin{tabular}{|c|c|c|}
\hline \multicolumn{2}{|r|}{ QUESTION } & RESPONSE \\
\hline 13. & If yes, please describe. & \\
\hline 14. & $\begin{array}{l}\text { During the 1987-88 school } \\
\text { year did your school have } \\
\text { a formal written policy } \\
\text { regarding student alcohol } \\
\text { and/or other drug abuse? }\end{array}$ & \\
\hline 15 & $\begin{array}{l}\text { How are staff and students } \\
\text { made aware of this policy? }\end{array}$ & \\
\hline 16. & $\begin{array}{l}\text { Your survey indicates that } \\
\text { approximately of } \\
\text { your school's students } \\
\text { during the } 1987-88 \text { school } \\
\text { year were identified as } \\
\text { being harmfully involved } \\
\text { with alcohol and/or other } \\
\text { drugs. What is your } \\
\text { definition of harmfully } \\
\text { involved, and what kind } \\
\text { of documentation do you } \\
\text { have to support the data } \\
\text { you reported? }\end{array}$ & \\
\hline
\end{tabular}




\begin{tabular}{|c|c|c|}
\hline & QUESTION & RESPONSE \\
\hline 17 & $\begin{array}{l}\text { According to the survey, } \\
\text { of your school's students } \\
\text { identified as being } \\
\text { harmfully involved with } \\
\text { alcohol and/or other drugs } \\
\text { during the 1987-88 school } \\
\text { year, approximately } \\
\text { of these students were } \\
\text { referred to special } \\
\text { services within the school } \\
\text { such as counseling. what } \\
\text { kinds of services were } \\
\text { made available, and what } \\
\text { kind of documentation do } \\
\text { you have to support this } \\
\text { data? }\end{array}$ & \\
\hline 18. & $\begin{array}{l}\text { According to the survey, } \\
\text { of your school's students } \\
\text { identified as being } \\
\text { harmfully involved with } \\
\text { alcohol and/or other drugs } \\
\text { during the } 1987-88 \text { school } \\
\text { year, approximately } \\
\text { of these students were } \\
\text { referred to special } \\
\text { services outside of the } \\
\text { school such as counseling } \\
\text { and/or formal assessment. } \\
\text { What kinds of services } \\
\text { were made available, and } \\
\text { what kind of documentation } \\
\text { do you have to support } \\
\text { this data? }\end{array}$ & \\
\hline 19. & $\begin{array}{l}\text { How are your students and } \\
\text { parents made aware of your } \\
\text { overall drug education } \\
\text { program? }\end{array}$ & \\
\hline
\end{tabular}




\begin{tabular}{|c|c|c|}
\hline & QUESTION & RESPONSE \\
\hline 20. & $\begin{array}{l}\text { How many of your school's } \\
\text { students at each grade } \\
\text { level during the 1987-88 } \\
\text { school year received } \\
\text { formal treatment for } \\
\text { chemical dependency and } \\
\text { how is this data } \\
\text { documented? }\end{array}$ & \\
\hline 21. & $\begin{array}{l}\text { How does your school's } \\
\text { drug education intervention } \\
\text { program utilize outside } \\
\text { agencies and organizations? }\end{array}$ & \\
\hline 22. & $\begin{array}{l}\text { What are the most } \\
\text { successful aspects of your } \\
\text { school's drug education } \\
\text { program? }\end{array}$ & \\
\hline 23. & $\begin{array}{l}\text { How can your school's drug } \\
\text { education program be } \\
\text { improved? }\end{array}$ & \\
\hline
\end{tabular}




\begin{tabular}{|c|c|c|}
\hline & QUESTION & RESPONSE \\
\hline 24. & $\begin{array}{l}\text { How does the central } \\
\text { office support your } \\
\text { school's drug education } \\
\text { program? }\end{array}$ & \\
\hline 25. & $\begin{array}{l}\text { How do parents and the } \\
\text { community support your } \\
\text { school's drug education } \\
\text { program, and how can you } \\
\text { gain more parental and } \\
\text { community support for your } \\
\text { program? }\end{array}$ & \\
\hline 26. & $\begin{array}{l}\text { Who is responsible for } \\
\text { managing and/or } \\
\text { administrating your } \\
\text { school's drug education } \\
\text { program and how much of } \\
\text { their workday is } \\
\text { dedicated to this task? }\end{array}$ & \\
\hline 27. & $\begin{array}{l}\text { What king of financial } \\
\text { resources are made } \\
\text { available for your } \\
\text { school's drug education } \\
\text { program? }\end{array}$ & \\
\hline
\end{tabular}




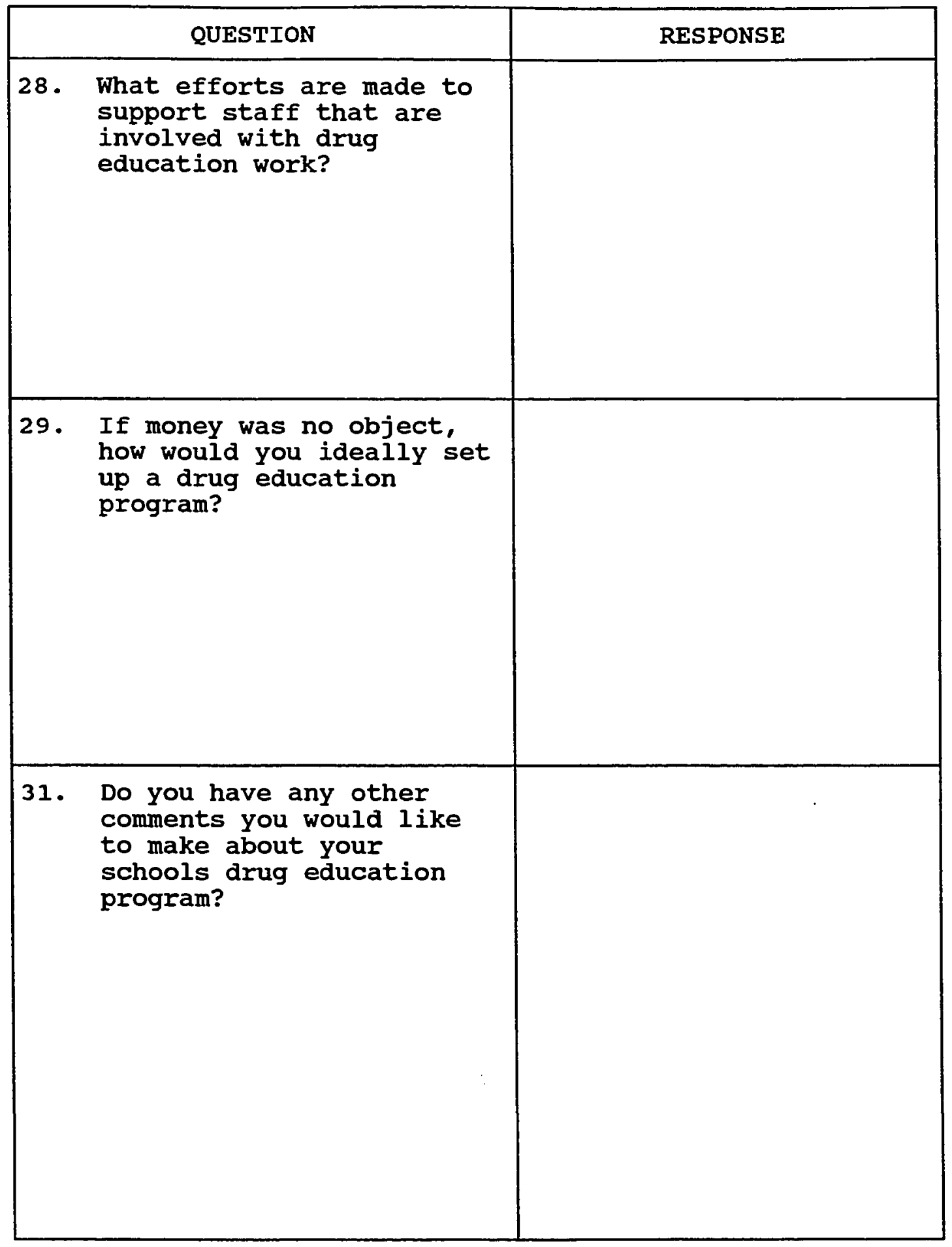

$1 / 21 / 89$ 
INTERVIEW FORM FOR TEACHERS AND SUPPORT STAFF

CASE SCHOOL IDENTIFICATION NUMBER

DATE

INTERVIEWER

\begin{tabular}{|c|c|}
\hline QUESTION & RESPONSE \\
\hline $\begin{array}{l}\text { 1. What kind of formal drug } \\
\text { education instruction } \\
\text { programs exist in your } \\
\text { school at each grade } \\
\text { level and what kind of } \\
\text { instruction do they } \\
\text { receive? }\end{array}$ & \\
\hline $\begin{array}{l}\text { 2. Please describe how your } \\
\text { school goes about } \\
\text { identifying students who } \\
\text { are harmfully involved } \\
\text { with alcohol and/or other } \\
\text { drugs? }\end{array}$ & \\
\hline $\begin{array}{l}\text { 3. What building staff } \\
\text { members in your school } \\
\text { participate in the } \\
\text { identification of students } \\
\text { who are harmfully involved } \\
\text { with alcohol and/or other } \\
\text { drugs, and what kind of } \\
\text { training have they } \\
\text { received? }\end{array}$ & \\
\hline $\begin{array}{l}\text { 4. What building staff in } \\
\text { your school are involved } \\
\text { in referring students who } \\
\text { are harmfully involved } \\
\text { with alcohol and/or other } \\
\text { drugs to some kind of } \\
\text { special service that meets } \\
\text { their needs, and what kind } \\
\text { of training have they } \\
\text { received? }\end{array}$ & \\
\hline
\end{tabular}




\begin{tabular}{|c|c|c|}
\hline & QUESTION & RESPONSE \\
\hline 5. & $\begin{array}{l}\text { Who are students referred } \\
\text { to if staff suspect that a } \\
\text { student is harmfully } \\
\text { involved with alcohol and/ } \\
\text { or other drugs? }\end{array}$ & \\
\hline 6. & $\begin{array}{l}\text { Who determines the } \\
\text { severity of a student's } \\
\text { problem, and whether or } \\
\text { not the student needs } \\
\text { special assistance? }\end{array}$ & \\
\hline & $\begin{array}{l}\text { Please describe what, if } \\
\text { any, student peer } \\
\text { assistance program you } \\
\text { have that includes } \\
\text { activities related to } \\
\text { substance abuse among } \\
\text { students? }\end{array}$ & \\
\hline & $\begin{array}{l}\text { How would a student refer } \\
\text { themselves or another } \\
\text { student to school staff } \\
\text { for possible problems } \\
\text { related to alcohol and } \\
\text { drug abuse? }\end{array}$ & \\
\hline
\end{tabular}




\begin{tabular}{|c|c|c|}
\hline & QUESTION & RESPONSE \\
\hline 9. & $\begin{array}{l}\text { How are students } \\
\text { instructed on how to do } \\
\text { this? }\end{array}$ & \\
\hline 10 & $\begin{array}{l}\text { Does your school have an } \\
\text { established process for } \\
\text { helping students obtain } \\
\text { formal assessment relative } \\
\text { to alcohol and/or other } \\
\text { drug abuse and chemical } \\
\text { dependency? }\end{array}$ & \\
\hline 11. & If yes, please describe. & \\
\hline 12. & $\begin{array}{l}\text { Does your school have an } \\
\text { established reentry } \\
\text { program for students } \\
\text { returning to your school } \\
\text { after having received } \\
\text { counseling or treatment } \\
\text { for alcohol and/or other } \\
\text { drug abuse? }\end{array}$ & \\
\hline
\end{tabular}




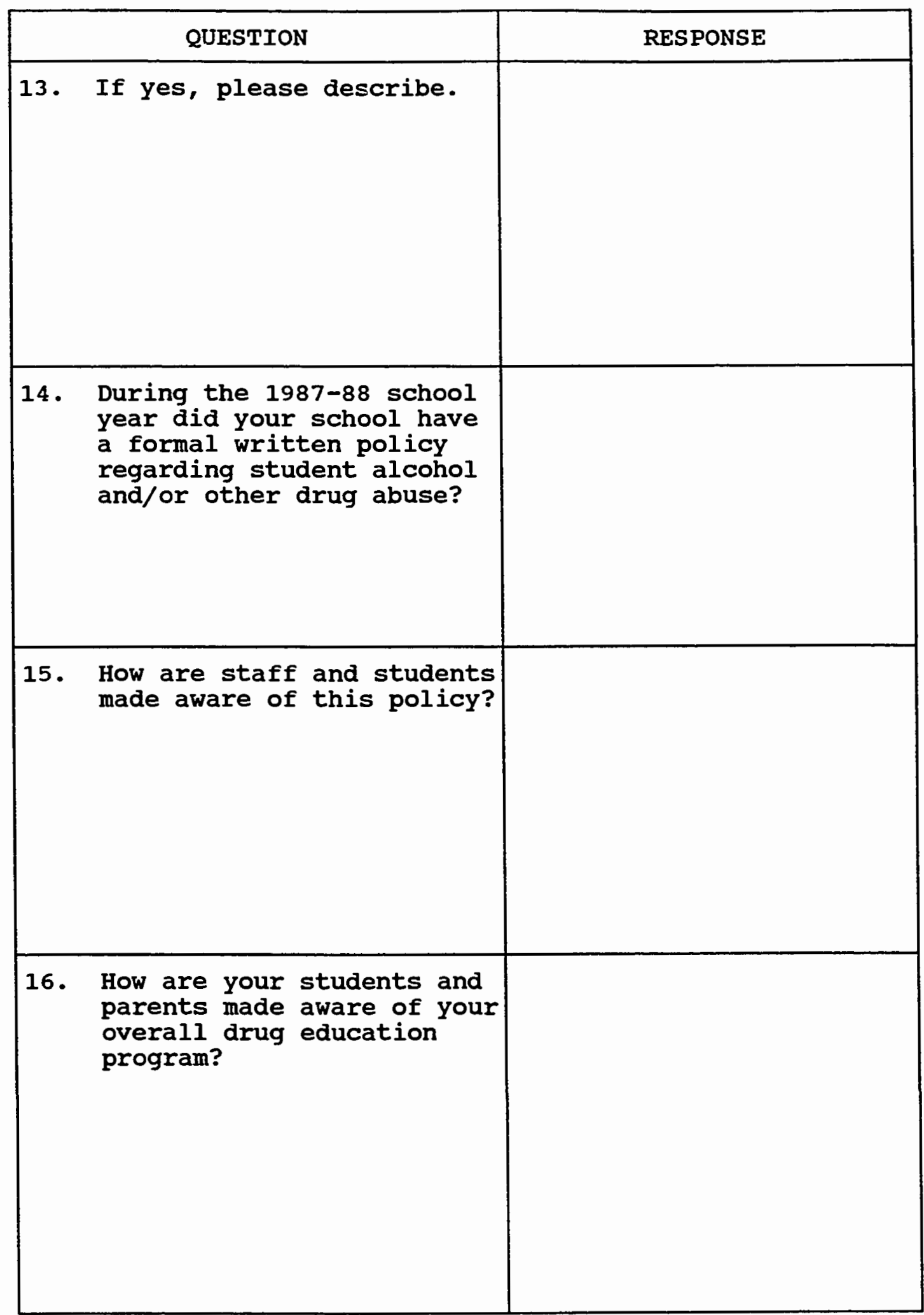




\begin{tabular}{|c|c|c|}
\hline \multicolumn{2}{|r|}{ QUESTION } & RESPONSE \\
\hline 17. & $\begin{array}{l}\text { How does your school's } \\
\text { drug education intervention } \\
\text { program utilize outside } \\
\text { agencies and organizations? }\end{array}$ & \\
\hline 18. & $\begin{array}{l}\text { What are the most } \\
\text { successful aspects of your } \\
\text { school's drug education } \\
\text { program? }\end{array}$ & \\
\hline 19. & $\begin{array}{l}\text { How can your school's drug } \\
\text { education program be } \\
\text { improved? }\end{array}$ & \\
\hline 20. & $\begin{array}{l}\text { How does the central } \\
\text { office and building } \\
\text { administration support } \\
\text { your school's drug } \\
\text { education program? }\end{array}$ & \\
\hline
\end{tabular}




\begin{tabular}{|c|c|c|}
\hline & QUESTION & RESPONSE \\
\hline 21. & $\begin{array}{l}\text { How do parents and the } \\
\text { community support your } \\
\text { school's drug education } \\
\text { program, and how can you } \\
\text { gain more parental and } \\
\text { community support for your } \\
\text { program? }\end{array}$ & \\
\hline 22 & $\begin{array}{l}\text { Who is responsible for } \\
\text { managing and/or } \\
\text { administrating your } \\
\text { school's drug education } \\
\text { program and how much of } \\
\text { their workday is } \\
\text { dedicated to this task? }\end{array}$ & \\
\hline 23. & $\begin{array}{l}\text { What king of financial } \\
\text { resources are made } \\
\text { available for your } \\
\text { school's drug education } \\
\text { program? }\end{array}$ & \\
\hline 24 & $\begin{array}{l}\text { What efforts are made to } \\
\text { support staff that are } \\
\text { involved with drug } \\
\text { education work? }\end{array}$ & \\
\hline
\end{tabular}




\begin{tabular}{|l|l|}
\hline \multicolumn{1}{|c|}{ QUESTION } & RESPONSE \\
\hline 25. If money was no object, \\
how would you ideally set \\
up a drug education \\
program?
\end{tabular}


INTERVIEW FORM FOR STUDENTS WHO HAVE NOT BEEN DIAGNOSED AS HAVING ABUSED ALCOHOL AND/OR OTHER DRUGS

CASE SCHOOL IDENTIFICATION NUMBER

DATE INTERVIEWER

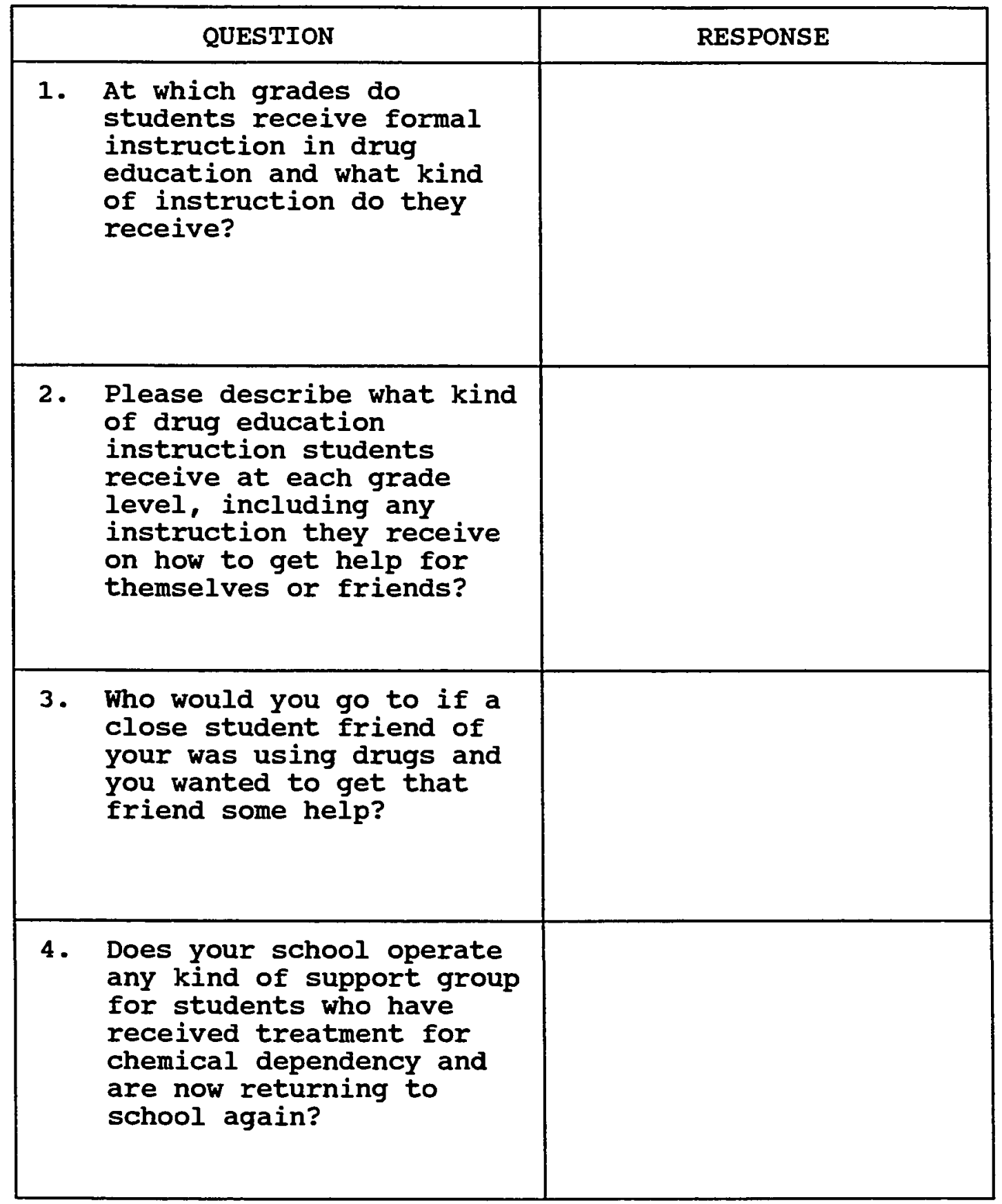




\begin{tabular}{|c|c|c|}
\hline & QUESTION & RESPONSE \\
\hline 5. & $\begin{array}{l}\text { Who would a student go to } \\
\text { if he/she wanted to get } \\
\text { help for themselves } \\
\text { regarding their own abuse } \\
\text { of alcohol and/or other } \\
\text { drugs? }\end{array}$ & \\
\hline 6. & $\begin{array}{l}\text { Does your school have an } \\
\text { established policy (rules } \\
\text { and regulations) regarding } \\
\text { student use of alcohol } \\
\text { and/or other drugs? }\end{array}$ & \\
\hline 7 & $\begin{array}{l}\text { What do you think your } \\
\text { school could do to } \\
\text { improve its drug } \\
\text { education program? }\end{array}$ & \\
\hline 8 & $\begin{array}{l}\text { Do you have any other } \\
\text { comments about your } \\
\text { school's drug education } \\
\text { program, or how drug } \\
\text { education programs in } \\
\text { schools can be improved? }\end{array}$ & \\
\hline
\end{tabular}


INTERVIEW FORM FOR STUDENTS WHO HAVE BEEN

DIAGNOSED AS HAVING ABUSED ALCOHOI AND/OR OTHER DRUGS

CASE SCHOOI IDENTIFICATION NUMBER

DATE INTERVIEWER

\begin{tabular}{|c|c|c|}
\hline & QUESTION & RESPONSE \\
\hline 1. & $\begin{array}{l}\text { At which grades do } \\
\text { students receive formal } \\
\text { instruction in drug } \\
\text { education and what kind } \\
\text { of instruction do they } \\
\text { receive? }\end{array}$ & \\
\hline 2 & $\begin{array}{l}\text { Please describe what kind } \\
\text { of drug education } \\
\text { instruction students } \\
\text { receive at each grade } \\
\text { level, including any } \\
\text { instruction they receive } \\
\text { on how to get help for } \\
\text { themselves or friends? }\end{array}$ & \\
\hline & $\begin{array}{l}\text { Who would you go to if a } \\
\text { close student friend of } \\
\text { your was using drugs and } \\
\text { you wanted to get that } \\
\text { friend some help? }\end{array}$ & \\
\hline & $\begin{array}{l}\text { Does your school operate } \\
\text { any kind of support group } \\
\text { for students who have } \\
\text { received treatment for } \\
\text { chemical dependency and } \\
\text { are now returning to } \\
\text { school again? }\end{array}$ & \\
\hline
\end{tabular}




\begin{tabular}{|c|c|c|}
\hline & QUESTION & RESPONSE \\
\hline & $\begin{array}{l}\text { Who would a student go to } \\
\text { if he/she wanted to get } \\
\text { help for themselves } \\
\text { regarding their own abuse } \\
\text { of alcohol and/or other } \\
\text { drugs? }\end{array}$ & \\
\hline 6. & $\begin{array}{l}\text { Does your school have an } \\
\text { established policy (rules } \\
\text { and regulations) regarding } \\
\text { student use of alcohol } \\
\text { and/or other drugs? }\end{array}$ & \\
\hline & $\begin{array}{l}\text { What do you think your } \\
\text { school could do to } \\
\text { improve its drug } \\
\text { education program? }\end{array}$ & \\
\hline & $\begin{array}{l}\text { Do you have any other } \\
\text { comments about your } \\
\text { school's drug education } \\
\text { program, or how drug } \\
\text { education programs in } \\
\text { schools can be improved? }\end{array}$ & \\
\hline
\end{tabular}


APPENDIX 1-M

THANK YOU LETTER TO BUILDING PRINCIPALS AFTER ONSITE VISITATION 


\section{APPENDIX 1-M}

January 27,1989

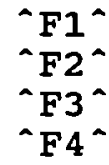

Dear `F5^:

Thank you again for participating in our study of drug education programs in Washington State's secondary public schools. I especially appreciate your hospitality and the work you did to coordinate my interviews with the various groups. It was enjoyable to meet with you and your staff, and I look forward to having our paths cross again sometime.

Just a reminder -- I will be sending you a copy of the visitation summary that will be submitted to the Bureau of Alcohol and Substance Abuse. The summary will overview the observations and recommendations from staff and students that participated in the 12 school visitation stage of our project.

Thank you again for your participation and assistance.

sincerely,

Todd Herberg, Administrative Assistant for Instructional Services

TH: nlc 
APPENDIX $1-\mathrm{N}$ 


\section{APPENDIX $1-\mathrm{N}$ \\ CASE STUDY REPORT}

CASE NUMBER

INTERVIEWER

DATE

This case study report is a descriptive analysis of a drug education intervention program observed during site visitations to each school in the multiple-case study. Data used in preparing the case study report includes interview responses from staff and students, documentary evidence collected at the school site and personal observations from the interviewer. The case study report format was developed using the established study questions for this project.

1. What kinds of formal drug education instruction programs exist in the school at each grade level?

2. What kind of formal program does the school have for identifying students who are harmfully involved with alcohol and/or other drugs?

3. Which school staff members participate in the identification of students who are harmfully involved with alcohol and/or other drugs?

4. What kind of formal training do staff members receive to help them identify students who are harmfully involved with alcohol and/or other drugs?

5. Which school staff members are involved in referring students who are harmfully involved with alcohol and/or other drugs to an appropriate service?

6. What kind of formal training do staff members 
receive to help them refer students who are harmfully involved with alcohol and/or other drugs to appropriate services?

7. Does the school have a student peer assistance program related to substance abuse among students?

8. Does the school have an established process for helping students obtain formal assessment relative to alcohol and/or other drug abuse and chemical dependency?

9. Does the school have an established reentry program for students returning after having received counseling or treatment for alcohol and/or other drug abuse?

10. During the 1987-88 school year, did the school have a formal written policy regarding student alcohol and/or other drug abuse, and are students aware of it?

11. How does the school's drug education intervention program utilize outside agencies and organizations?

12. What are the most important aspects of your school's drug education intervention program?

13. How does central office administration and building administration support the school's drug education intervention program?

14. How does the community support the school's drug education intervention program?

15. How is the school's drug education intervention program managed (administered)?

16. How can the school's drug education intervention program be improved? 
APPENDIX 2

CHARTS AND GRAPHS 


\author{
APPENDIX 2 \\ IDENTIFICATION AND REFERRAL RATES \\ IN WASHINGTON STATE'S PUBLIC \\ HIGH SCHOOLS
}


IDENTIFICATION AND REFERRAL RATIOS

\begin{tabular}{|c|c|c|c|c|c|c|c|}
\hline CASEI & ENROLL' & Q18! & Q19! & Q20! & Q21! & Q22! & ID/ENROLL \\
\hline \multicolumn{8}{|c|}{$1-499$ student enroilment } \\
\hline 111 & $57 !$ & & & & & & 0.000 \\
\hline $542 !$ & $94 !$ & o) & o] & 이 & 이 & oị & 0.000 \\
\hline $49 !$ & 157 ị & & 5) & 5 & 5) & 5 & 0.000 \\
\hline $124 !$ & 183 & & 1 & 1 & & $!$ & 0.000 \\
\hline 396 & 219 & 이 & 0 & o) & & 5 & 0.000 \\
\hline $91 \mid$ & 224 & & & & & & 0.000 \\
\hline 433 & 237 & & & & & & 0.000 \\
\hline 267 & 2681 & & & & & 1 & 0.000 \\
\hline 598 & 400 & & & & & 1 & 0.000 \\
\hline 105 & 427 & & & & & $3 !$ & 0.000 \\
\hline 285 & 287 & 1 & 1 & 11 & 1) & $1 !$ & 0.003 \\
\hline 573 & $275 !$ & 1 & 11 & 1 & 1 & $1 !$ & 0.004 \\
\hline 487 & $479 !$ & 3) & 0 & o) & o! & 0 & 0.006 \\
\hline 366 & 150 & 11 & 1 & 11 & o! & $0_{i}^{i}$ & 0.007 \\
\hline 82! & 262 & 2) & 2 & 2! & 2) & 2 & 0.008 \\
\hline 281 & 125 & 1) & 11 & 11 & 1 & 1 & 0.008 \\
\hline 456 & 196 & 2) & 2) & 2) & 2) & $2 !$ & 0.010 \\
\hline 602 & 152 & 2) & 1 & 2) & 1 & 1 & 0.013 \\
\hline 480 & 418 & 8 & 8 & 8 & 31 & $1 i$ & 0.019 \\
\hline $345 !$ & 449 & 9) & 9! & 9) & 9) & $130^{i}$ & 0.020 \\
\hline 214 & $241 !$ & 5) & $5 !$ & 2 & 2) & $1 !$ & 0.021 \\
\hline $381 \mid$ & 135 & 3. & 1 & 3 & 1 & $i$ & 0.022 \\
\hline $327 \mid$ & 167 & 4 & of & 3 & of & 2 & 0.024 \\
\hline 179 & 208 & 5 & $1\}$ & 2 & 1 & $1 !$ & 0.024 \\
\hline 184 & 111 & 3 & 3) & 3) & 3 & 3 & 0.027 \\
\hline 400 & 435 & 12 & 1 & 12 & 8 & 6 & 0.028 \\
\hline 65 & 322 & 9) & 5 & 4 & 4 & 4 & 0.028 \\
\hline 6031 & $100 \mid$ & 3 & 1) & 7 & 1 & 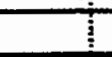 & 0.030 \\
\hline 4201 & $255 !$ & 8 & 8 & 2 & 1 & 11 & 0.031 \\
\hline $173 \mid$ & 440 & 14 & 7 & 10 & 71 & 31 & 0.032 \\
\hline 42) & 345 & 11! & 11 & 11 & 11 & 31 & 0.032 \\
\hline 104 & 199| & 7 & 4) & 1 & & i & 0.035 \\
\hline 88 & $246 !$ & 9 & 2 & 2 & 7 & 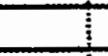 & 0.037 \\
\hline 78 & $280 \mid$ & 11 & 11 & 11 & 2 & 2 & 0.039 \\
\hline 534 & 460 & 19 & 16 & 7 & & $6 !$ & 0.041 \\
\hline 3511 & 360 & 15 & 11 & 4 & 6 & $4 !$ & 0.042 \\
\hline 553 & 354) & 15 & 15 & 13 & 2 & 2 & 0.042 \\
\hline 315 & 415! & 201 & 20 & 20 & 13 & $2 !$ & 0.048 \\
\hline 415 & 90। & 5 & & & 1 & I & 0.056 \\
\hline 431 & 124 & 7 & 71 & 7 & 3) & $3 !$ & 0.056 \\
\hline 482 & 140 & 8 & 5 & 3 & 3 & 2) & 0.057 \\
\hline 245 & 277 & 18 & 18 & 9 & 9 & 5 & 0.065 \\
\hline 136 & 450 & 30 & 30 & 30 & 15 & (8) & 0.067 \\
\hline 282 & $156 !$ & 111 & $11 \mid$ & 6) & 2) & & 0.071 \\
\hline
\end{tabular}




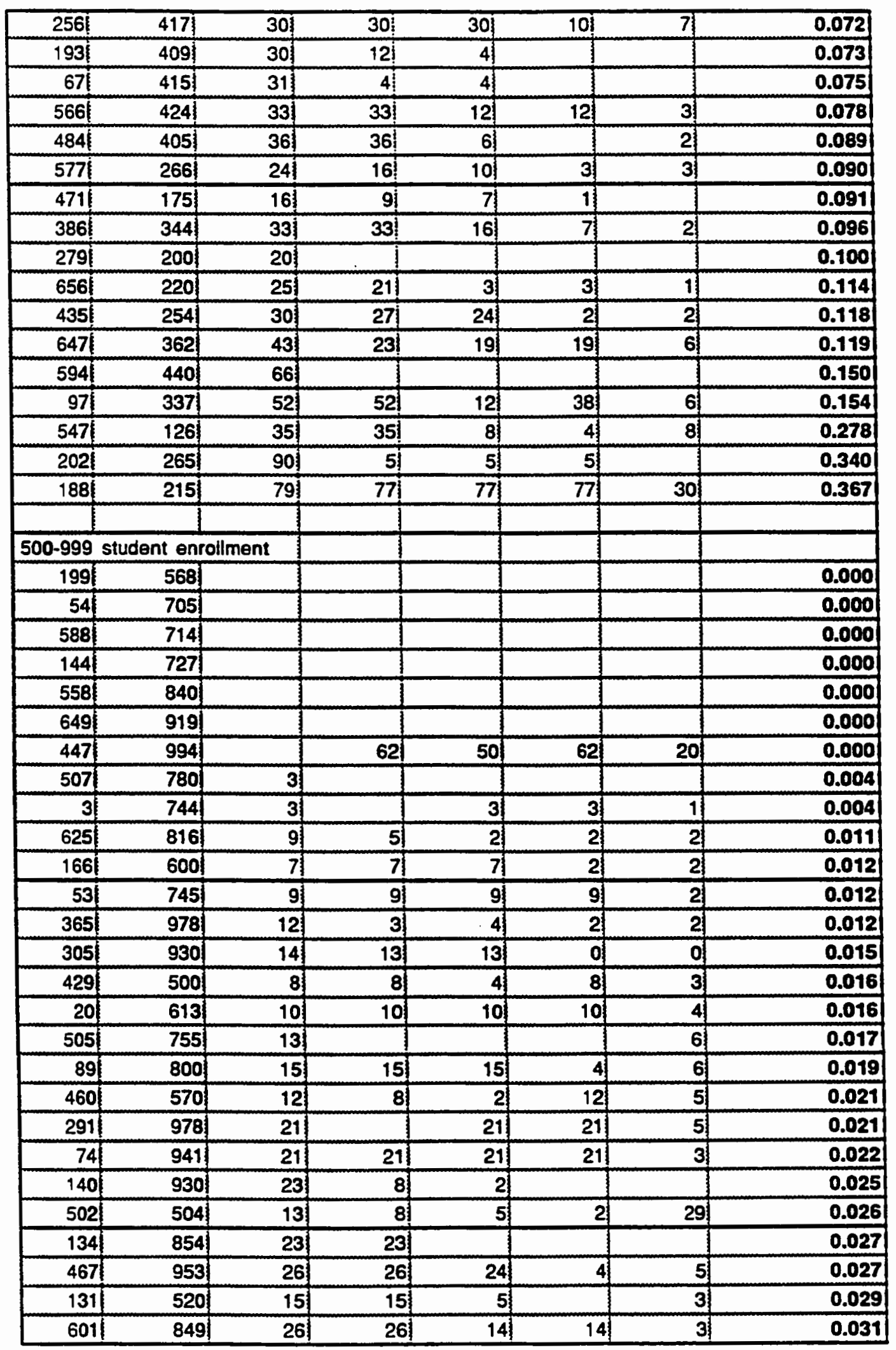




\begin{tabular}{|c|c|c|c|c|c|c|c|}
\hline 544 & $658 !$ & 221 & $22 !$ & 22 & $22 !$ & 221 & 0.033 \\
\hline 130 & 750 & 32 & 32 & 20 & $15 !$ & 15 & 0.043 \\
\hline 221 & 710 & 32 & 24) & $19 \mid$ & $19 !$ & 9 & 0.045 \\
\hline $436 !$ & 599 & 27 & 16 & 11 & $26 !$ & 7 & 0.045 \\
\hline 562 & 926 & 42) & 42 & $36 !$ & $5 !$ & 6 & 0.045 \\
\hline 629 & 615 & 31 & $31 !$ & 311 & 15 & $5 !$ & 0.050 \\
\hline 175 & 757 & 40 & 40 & 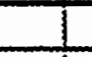 & 1 & $20 !$ & 0.053 \\
\hline 617 & $528 !$ & 28 & 16 & 8) & 11 & 7) & 0.053 \\
\hline $90 !$ & $960 !$ & 511 & 51 & 1 & $51 !$ & 7 & 0.053 \\
\hline 325 & 940 & 50 & 32 & 5 & $2\}$ & 1 & 0.053 \\
\hline $30 !$ & 880 & 49. & 22 & $23 !$ & $14 !$ & 8) & 0.056 \\
\hline 153 & 510 & 30 & 30 & 11 & 11 & 2 & 0.059 \\
\hline 791 & 726 & $55 !$ & 31: & 6 & 7 & 1 & 0.076 \\
\hline 512 & 611 & 491 & & 2) & 3) & 3) & 0.080 \\
\hline 461 & 610 & 50 & 50 & 13 & 11 & 10 & 0.082 \\
\hline 613 & 914 & 771 & 77 & 27. & 27 & $9)$ & 0.084 \\
\hline 579 & $530 !$ & 45 & 22) & 55 & & 15 & 0.085 \\
\hline 610 & 505 & 43 & 31 & 13! & 31) & 19: & 0.085 \\
\hline 357 & 940 & 90 & 511 & 40! & 22 & 11 & 0.096 \\
\hline 624 & 549 & 55 & 125 & 31) & & 2 & 0.100 \\
\hline 652 & 8871 & 90 & 70 & 34) & 20 & 201 & 0.101 \\
\hline 536 & 915 & 120 & 36 & 30 & 30) & 6) & 0.131 \\
\hline $190 \mid$ & 8881 & 144 & 116 & 77 & 11 & 9) & 0.162 \\
\hline 370 & 8501 & 200 & 47. & 8) & & & 0.235 \\
\hline 591 & 994| & 250 & 250 & 100 & 35 & 20 & 0.252 \\
\hline \multirow{2}{*}{\multicolumn{8}{|c|}{ 1000-1499 student enroilment }} \\
\hline & & & & & & & \\
\hline 375 & 1100 & & & & & & 0.000 \\
\hline 407 & 1100 & & & & & 15 & 0.000 \\
\hline 711 & 1100 & & & & & & 0.000 \\
\hline 471 & 1362 & & & & & & 0.000 \\
\hline 518 & 1419 & & & & & & 0.000 \\
\hline 324 & 1460 & 4 & 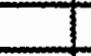 & 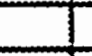 & & 1 & 0.000 \\
\hline 421 & 1172 & 3) & 1 & 2 & 2 & 2 & 0.003 \\
\hline 623 & 1029 & 7 & & 7 & 7 & 7) & 0.007 \\
\hline 499 & 1037 & 8 & 8) & 8 & 1 & $2 !$ & 0.008 \\
\hline 287 & 1000 & 8 & 5 & 5 & 71 & 3) & 0.008 \\
\hline 342 & 1028 & 12 & 12 & 12 & 12 & 7) & 0.012 \\
\hline 372 & $1191 !$ & 15) & 15) & 15 & 15 & 4] & 0.013 \\
\hline 119 & 1050 & 14) & 14! & 14 & 14! & 5 & 0.013 \\
\hline 528 & 1459 & 21) & 10 & 7 & & 7) & 0.014 \\
\hline 350 & 1227 & 18 & of & 18 & 18 & 6 & 0.015 \\
\hline 213 & 1350 & 20 & 20 & 12 & 12 & 7 & 0.015 \\
\hline 217 & 1300 & 23 & 23 & 10 & 10 & 15 & 0.018 \\
\hline 398 & 1300 & 24) & 24 & 24 & 6 & 3 & 0.018 \\
\hline 155 & 1345 & 26 & 12! & 10 & $5 !$ & & 0.019 \\
\hline
\end{tabular}




\begin{tabular}{|c|c|c|c|c|c|c|c|}
\hline 2311 & 1200 & 301 & 12 & $18 !$ & 18 & 8 & 0.025 \\
\hline 234 & 1174 & 30 & 25 & & & & 0.026 \\
\hline 568 & 1048 & 27) & $27 !$ & 25) & & 7 & 0.026 \\
\hline 154 & 1346 & 35 & 10! & 35 & 10 & 5 & 0.026 \\
\hline 382 & 1030 & 27) & 111 & 14 & $14 !$ & 3) & 0.026 \\
\hline 183 & 1465 & 39 & $39 !$ & 23) & 23 & 15 & 0.027 \\
\hline 586 & 1217 & 34 & 10 & 24 & 34 & 8) & 0.028 \\
\hline 163 & 1200 & $35 \mid$ & 35 & 20 & 35 & 9] & 0.029 \\
\hline 637 & 1238 & 40] & 40 & 20 & 20 & 18 & 0.032 \\
\hline 462 & 1391 & 46 & 35 & - & 1 & 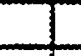 & 0.033 \\
\hline 34 & 1310 & 44 & 1 & 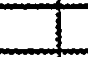 & 44 & 12) & 0.034 \\
\hline 265 & 1447 & 50) & 21! & 21) & 4 & 22 & 0.035 \\
\hline 44 & 1215 & 42 & 18! & 34 & 18 & 14 & 0.035 \\
\hline 458 & 1206 & 42) & 42! & 35 & 35 & -1 & 0.035 \\
\hline 622 & 1282 & 47 & 47 & 25 & 12 & 12 & 0.037 \\
\hline 264 & 1200 & $44 !$ & 1 & $14 \mid$ & 14! & $m$ & 0.037 \\
\hline 151 & 1144 & 42) & 42 & 18) & 18 & 3) & 0.037 \\
\hline 369 & 1095 & 411 & $33 !$ & 23 & 23 & 7) & 0.037 \\
\hline 476 & 1135 & 45 & 45 & $\rightarrow$ & $\longrightarrow$ & 7) & 0.040 \\
\hline 310 & 1233 & 49) & 49 & 21 & 21 & 9) & 0.040 \\
\hline 606 & 1100 & 45 & 45! & 25) & 19 & 7 & 0.041 \\
\hline 259 & 1058 & 45) & 31 & 27 & $m$ & 17 & 0.043 \\
\hline 237 & 1390 & 60! & 8 & 4 & 3) & 5 & 0.043 \\
\hline 646 & 1135 & 53) & 53! & 53) & 23 & 23 & 0.047 \\
\hline 497 & 1428 & 67 & 34 & 20 & 20: & 5 & 0.047 \\
\hline 56 & 1200 & 57 & 57) & 57) & 57 & 12 & 0.048 \\
\hline 761 & 1150 & 64 & 56 & & 18 & 12 & 0.056 \\
\hline 38) & 1004 & 66 & \begin{tabular}{l|l}
46 \\
\end{tabular} & 46 & 46 & 6 & 0.066 \\
\hline 225 & 1451 & 98) & 1 & 1 & 48) & 21 & 0.068 \\
\hline 99! & 1465 & 100 & 32 & 68) & 39) & 34 & 0.068 \\
\hline 156 & 1441 & 101 & 1011 & 23 & 23) & 11] & 0.070 \\
\hline 32 & 1328 & 100 & 50 & 50 & 22 & 40 & 0.075 \\
\hline 125 & 1153 & 90 & 100 & 55 & 55 & 10 & 0.078 \\
\hline 248 & 1480 & 120 & 80 & 10) & 40 & 16 & 0.081 \\
\hline 33 & 1353 & 110 & 94 & 17| & & 7 & 0.081 \\
\hline 73 & 1228 & 106 & $106 !$ & 40 & 28 & 11 & 0.086 \\
\hline 266 & 1247 & 122 & $76 !$ & 62 & 76 & 8 & 0.098 \\
\hline 506 & 1250 & 127 & 127) & 127 & 66: & 11) & 0.102 \\
\hline 300 & 1400 & 150 & 301 & 30 & 20 & 20 & 0.107 \\
\hline 397 & 1476 & 167 & 84 & 87 & 70 & 14 & 0.113 \\
\hline 371 & 1302 & 150 & 75 & 5 & 80 & 20 & 0.115 \\
\hline 164 & 1099 & 140 & 140 & 48 & 48 & 10 & 0.127 \\
\hline \begin{tabular}{|l|}
$466 \mid$ \\
\end{tabular} & 1020 & 130 & 65 & 12 & 19| & 16 & 0.127 \\
\hline 35 & 1300 & 187 & 187) & 187 & 82 & 17 & 0.144 \\
\hline 422 & 1216 & 180 & $23 !$ & 7 & 5 & 5 & 0.148 \\
\hline 517 & 1154 & 394 & 30 & 4) & & 9) & 0.341 \\
\hline
\end{tabular}




\begin{tabular}{|c|c|c|c|c|c|c|c|}
\hline 543 & 1336 & 655 & $91 !$ & $30 \mid$ & $14 !$ & 9 & 0.490 \\
\hline & & & 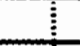 & & & & \\
\hline \multicolumn{8}{|c|}{1500 and more student enroliment } \\
\hline 252 & 1500 & & 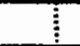 & & & & 0.000 \\
\hline 572 & 1575! & & 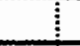 & & & & 0.000 \\
\hline 488 & 1598 & & $\underline{u}$ & & & & 0.000 \\
\hline 472 & 1600 & & 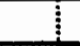 & & & 18 & 0.000 \\
\hline $123 \mid$ & 1700 & & & 25 & 25 & $6)$ & 0.000 \\
\hline 61) & 2038 & & : & 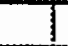 & 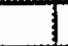 & & 0.000 \\
\hline 28 & 2100 & o) & 0 & 0) & O: & o) & 0.000 \\
\hline 520 & 1688 & 23 & $14 !$ & 9] & 13 & 6) & 0.014 \\
\hline 532 & 2044 & 33 & 33 & 23 & 34 & 7 & 0.016 \\
\hline 640 & 1850 & 45 & 14 & 25 & 14 & 20 & 0.024 \\
\hline 288 & 1576 & 48 & 413 & 21 & 15 & 10 & 0.030 \\
\hline 388 & 1519 & 66 & 29 & 15 & 15 & 13 & 0.043 \\
\hline 330 & 1540 & 70 & $52 !$ & 32 & 21 & 9] & 0.045 \\
\hline 262 & 1600 & 77) & 77 & $42 !$ & 26) & 26 & 0.048 \\
\hline 401 & 1550 & 80 & $20 !$ & & 40 & 281 & 0.052 \\
\hline 196 & 1500 & 143 & 51) & 50 & 51 & 20 & 0.095 \\
\hline 341 & 1700 & 250 & 120 & $2)$ & 2 & 2) & 0.147 \\
\hline
\end{tabular}


APPENDIX 3

CASE REPORTS 


\section{APPENDIX $3^{1}$}

CASE REPORTS

CASE 1 SUMMARY

Case Number 1 was identified through the original survey as being successful in its ability to identify students harmfully involved with alcohol and/or other drugs and refer these students to appropriate services. Case Numioer 1 is a suburban high school with approximately 300 students in grades 9-12.

Question 1. What kinds of formal drug education instruction programs exist in the school at each grade level?

Answer 1. There is no formal drug education instruction program. Some teachers address drug education issues in family living classes and social studies classes, etc. The only instruction that all students would receive is a brief unit that is part of the high school health program. This class could be taken at any grade level.

Question 2. What kind of formal program does the

1 For more specific demographic information regarding the twelve case study schools, please write: Drug Education Department, Educational Service District 114, 105 National Avenue North, Bremerton, WA 98312 
school have for identifying students who are harmfully involved with alcohol and/or other drugs?

Answer 2. The school has a formal student assistance program with the core team concept. staff are trained in identifying students who are harmfully involved with alcohol and/or other drugs and referring them to administration. In addition, students coming into the school take a survey and assessment that helps identify students harmfully involved.

Question 3. Which school staff members participate in the identification of students who are harmfully involved with alcohol and/or other drugs?

Answer 3. All staff members participate in the identification of students and most of the staff members have been trained specifically in identification strategies.

ouestion 4. What kind of formal training do staff members receive to help them identify students who are harmfully involved with alcohol and/or other drugs?

Answer 4. Staff members receive training in identification strategies as well as overall drug education issues including information that enable staff to understand the kinds of problems that children are experiencing when they are harmfully involved with alcohol and/or other drugs. Question 5. Which school staff members are involved in referring students who are harmfully involved with alcohol and/or other drugs to an appropriate service?

Answer 5. School administration and counselors are 
involved with referring students to appropriate services. Referrals are most often a collaborative effort.

Question 6. What kind of formal training do staff members receive to help them refer students who are harmfully involved with alcohol and/or other drugs to appropriate services?

Answer 6. Counselors and administration have all had extensive core team training and most of these people are certified by the Bureau of Alcohol and substance Abuse (BASA) as drug education counselors.

Question 7. Does the school have a student peer assistance program related to substance abuse among students?

Answer 7. The school does not have a peer coaching assistance program.

Question 8. Does the school have an established process for helping students obtain formal assessment relative to alcohol and/or other drug abuse and chemical dependency?

Answer 8. The district contracts with a private provider to make formal assessments available to students at no cost.

Question 9. Does the school have an established reentry program for students returning after having received counseling or treatment for alcohol and/or other drug abuse? Answer 9. The school has a daily support class for 
students reentering school after having received counseling or treatment. The class is conducted by a highly trained individual who also facilitates weekly support groups that the students can also attend.

Question 10. During the 1987-88 school year, did the school have a formal written policy regarding student alcohol and/or other drug abuse, and are students aware of it?

Answer 10. Yes, the school did have a formal written policy regarding student alcohol and/or other drug abuse. The policy is widely distributed in school literature including a student handbook. All students are made aware of the policy during an initial orientation that all students participate in when entering this school. The orientation is conducted with all incoming students regardless of their grade level.

Question 11. How does the school's drug education intervention program utilize outside agencies and organizations?

Answer 11. The school's program utilizes treatment agencies for some staff training. No community organizations are involved with this school's intervention program. Question 12. What are the most important aspects of your school's drug education intervention program?

Answer 12. When asked to describe the most important aspects of their school's drug education intervention 
program, staff and administration alike identified the importance of several services that are critically important. The critical services include: formal efforts to identify students, extensive staff training in identification strategies, a formal assessment service for students, the daily recovery classes for students and the weekly support groups for students.

Question 13. How does central office administration and building administration support the school's drug education intervention program?

Answer 13. Central office administration is credited for making financial resources available that the school can utilize for staff training and the contracting for assessment services. The central office is also credited for encouraging districtwide development of $\mathrm{K}-12$ drug education programs. The building administrative support is described by staff as being excellent. Building administration exhibits an extremely high level of commitment and enthusiasm to drug education intervention services, and the issues of drug education are a building priority. This translates into building resources being made available for teacher training and materials. Building administration also is responsible for the formation of the daily recovery class and weekly support groups.

Question 14. How does the community support the school's drug education intervention program? 
Answer 14. According to administration and other staff, the community support for the school's drug education intervention program is nonexistent. This semi-urban school staff does not feel that it exists within a community with a unique identity, and local businesses and other community groups have shown no interest in assisting in their drug education efforts. However, the staff also recognizes that they have not made it a priority to seek community support for this program.

Question 15. How is the school's drug education intervention program managed (administered)?

Answer 15. This school's drug education intervention program receives overall management from the school's vice principal. The vice principal facilitates group meetings and also conducts much of the case management for students who have been identified as being harmfully involved with alcohol and/or other drugs. Counselors operating the reentry classes and support groups are also responsible for case management and participate in group meetings where students are evaluated as to their harmful involvement with alcohol and/or other drugs.

Question 16. How can the school's drug education intervention program be improved?

Answer 16. Staff and administration alike recognize additional financial resources as a key to improving their existing drug education intervention program. Additional 
resources are required to provide additional and continued staff training in drug education related issues. Also, staff and administration feel that additional staff time is needed to properly manage and coordinate the intervention program.

\section{CASE 2 SUMMARY}

Case Number 2 was identified through the original survey as being successful in its ability to identify students harmfully involved with alcohol and/or other drugs and refer these students to appropriate services. Case Number 2 is a rural high school with approximately 250 students in grades 9-1:2.

Question 1. What kinds of formal drug education instruction programs exist in the school at each grade level?

Answer 1. The school has no formal drug education instruction programs except for a unit that is part of the required health class. Most students take these classes as a sophomore, but all students must take the class before graduating.

Question 2. What kind of formal program does the school have for identifying students who are harmfully involved with alcohol and/or other drugs?

Answer 2. Administrators and counselors work to identify students they suspect are harmfully involved with 
alcohol and/or other drugs and refer these students to a drug education counseling specialist who is onsite once a week.

Question 3. Which school staff members participate in the identification of students who are harmfully involved with alcohol and/or other drugs?

Answer 3. All school staff participate in identifying students who are harmfully involved with alcohol and/or other drugs, although most identification is done through the counselors and administrators.

Question 4. What kind of formal training do staff members receive to help them identify students who are harmfully involved with alcohol and/or other drugs?

Answer 4. Counselors and administrators have received specific training in identifying students who are harmfully involved with alcohol and/or other drugs. Although some other school staff have received limited training in this area, most staff have not been trained in identifying students who are harmfully involved with alcohol and/or other drugs.

Question 5. Which school staff members are involved in referring students who are harmfully involved with alcohol and/or other drugs to an appropriate service?

Answer 5. Building administrators and counselors are involved in referring students to appropriate services. Building administrators typically work with students who 
have been identified through disciplinary means, whereas, counselors typically work with students who have been identified through other means.

Question 6. What kind of formal training do staff members receive to help them refer students who are harmfully involved with alcohol and/or other drugs to appropriate services?

Answer 6. Administrators and counselors have both received training through contracted services with regard to referring students to appropriate services. The drug education specialist who also works with students in referring them to appropriate services has received extensive training in this area.

Question 7. Does the school have a student peer assistance program related to substance abuse among students?

Answer 7. Yes, the school does have a student peer assistance program related to substance abuse among students. The school operates a Natural Helpers program that discourages the use of alcohol and/or other drugs by students through an intensive training program. students are also trained to help identify students that may have problems with alcohol and/or other drugs and assist in getting these students help.

Question 8. Does the school have an established process for helping students obtain formal assessment 
relative to alcohol and/or other drug abuse and chemical dependency?

Answer 8. Yes, the school provides formal assessment services to students through a contractual arrangement with a private provider.

Question 9. Does the school have an established reentry program for students returning after having received counseling or treatment for alcohol and/or other drug abuse?

Answer 9. No, the school does not have an established reentry program although counselors and administrators indicate that they try to assist students in this situation by talking to them regularly.

Question 10. During the 1987-88 school year, did the school have a formal written policy regarding student alcohol and/or other drug abuse, and are students aware of it?

Answer 10. Yes, during the 1987-88 school year the school did have a formal written policy regarding student alcohol and/or other drug abuse. The students were made aware of this policy through a student handbook and student orientation.

Question 11. How does the school's drug education intervention program utilize outside agencies and organizations?

Answer 11. Both the Kiwanis Club and Elks Club contribute money to sponsor student activities that are part 
of the school's drug education intervention program.

Question 12. What are the most important aspects of your school's drug education intervention program?

Answer 12. Teachers and support staff feel that the assessment services and a strong discipline policy are the most important aspects of the school's drug education intervention program. Administration also feels that the availability of assessment services are critical to the intervention program's success.

Question 13. How does central office administration and building administration support the school's drug education intervention program?

Answer 13. Staff indicate that they enjoy strong support from both central office administration and building administration for the school's drug education intervention program. This support includes the allocation of resources for training and the assessment services.

Question 14. How does the community support the school's drug education intervention program?

Answer 14. Although community organizations contribute resources to the school's drug education intervention program, school staff would like to see more parents actively involved in the program.

Question 15. How is the school's drug education intervention program managed (administered)?

Answer 15. The school's drug education intervention 
program is managed primarily by the school counselor who works closely with the contracted drug education specialist. Question 16. How can the school's drug education intervention program be improved?

Answer 16. Staff and administration agreed that the school's drug education intervention program could be improved through additional staff training. They also felt that additional funding that would allow the establishment of a formal reentry program or support groups would be very beneficial. Students feel that the school needs to provide much more general information about drug abuse and that classes about drug abuse should be available at every grade level. Students who have been harmfully involved with alcohol and/or other drugs express a need for support groups and an increased knowledge level among school staff regarding the problems that students experience when they have been harmfully involved with alcohol and/or other drugs.

\section{CASE 3 SUMMARY}

Case Number 3 was identified through the original survey as being unsuccessful in its ability to identify students harmfully involved with alcohol and/or other drugs and refer these students to appropriate services. Case Number 3 is a rural high school with approximately 300 students in grades $9-12$. 
Question 1. What kinds of formal drug education instruction programs exist in the school at each grade level?

Answer 1. No formal drug education instruction takes place at any grade level in the high school.

Question 2. What kind of formal program does the school have for identifying students who are harmfully involved with alcohol and/or other drugs?

Answer 2. The school has no formal program for identifying students who are harmfully involved with alcohol and/or other drugs. If any students are identified as being harmfully involved with alcohol and/or other drugs, it is through a disciplinary referral or teacher/administrator observation at student activities such as dances and ball games.

Question 3. Which school staff members participate in the identification of students who are harmfully involved with alcohol and/or other drugs?

Answer 3. Administrators have the primary responsibility in identifying students who are harmfully involved with alcohol and/or other drugs through the disciplinary process.

Question 4. What kind of formal training do staff members receive to help them identify students who are harmfully involved with alcohol and/or other drugs?

Answer 4. No staff members have received training in 
identifying students who are harmfully involved with alcohol and/or other drugs.

Question 5. Which school staff members are involved in referring students who are harmfully involved with alcohol and/or other drugs to an appropriate service?

Answer 5. Although no formal referral process exists, the principal or the school counselor would be responsible for referring students to appropriate services if they were found to be harmfully involved with alcohol and/or other drugs. Administration could not recall any students being identified and referred during the 1987-88 school year.

Question 6. What kind of formal training do staff members receive to help them refer students who are harmfully involved with alcohol and/or other drugs to appropriate services?

Answer 6. No staff members have received formal training that would help them to refer students harmfully involved with alcohol and/or other drugs to appropriate services.

Question 7. Does the school have a student peer assistance program related to substance abuse among students?

Answer 7. The school has no student peer assistance program although they plan to start one.

question 8. Does the school have an established process for helping students obtain formal assessment 
relative to alcohol and/or other drug abuse and chemical dependency?

Answer 8. The school has no established process for helping students obtain formal assessment relative to alcohol and/or other drug abuse in chemical dependency. Furthermore, the school administrator and counselor could not recall any student receiving a formal assessment through any other service organization or agency during the 1987-88 school year.

Question 9. Does the school have an established reentry program for students returning after having received counseling or treatment for alcohol and/or other drug abuse? Answer 9. The school had no reentry program for students.

Question 10. During the 1987-88 school year, did the school have a formal written policy regarding student alcohol and/or other drug abuse, and are students aware of it?

Answer 10. The school did have a formal written policy regarding student alcohol and/or other drug use during the 1987-88 school year and the policy was made available to students through class orientation and the student handbook. The policy refers only to disciplinary procedures regarding any students using alcohol and/or other drugs.

Question 11. How does the school's drug education 
intervention program utilize outside agencies and organizations?

Answer 11. The local Lion club has previously funded a drug education activity at the middle school level, but there is no involvement of outside agencies and organizations in the high school.

Question 12. What are the most important aspects of your school's drug education intervention program?

Answer 12. The only observation that staff or administration could make regarding the important aspects of the school's drug education intervention program was that the school had a chapter of students Against Drug Driving (SADD) - However, staff and administration felt that greater participation by students was necessary in order to make the SADD chapter effective.

Question 13. How does central office administration and building administration support the school's drug education intervention program?

Answer 13. Although staff fee that the central office and building administration recognizes the problems, they just don't have any resources that can be committed to drug education efforts. During the interview, building administration admitted that they would like to become much more active in developing drug education programs. Teachers and support staff observe that administrative support was going to be needed if the school was going to get any kind 
of successful drug education intervention program.

Question 14. How does the community support the school's drug education intervention program?

Answer 14. Staff and administration agree that their is no significant community support for the school's drug education intervention program.

Question 15. How is the school's drug education intervention program managed (administered)?

Answer 15. The school's drug education intervention program is primarily managed by the school principal who is in charge of student discipline, although the building counselor also assists in this area.

Question 16. How can the school's drug education intervention program be improved?

Answer 16. Staff and administration both indicate that extensive training in drug education issues for staff and administration is a critical need. Also, the school needs more financial resources that can be used to pay for training and materials. Staff indicate that drug education programs should be available for students at all grade levels, and that students need to have access to someone with a good background in drug education. students expressed a need to have access to confidential counseling and support groups regarding drug abuse issues. students also stated they it would be helpful if required coursework was made available to all students regarding drug education 
and they school staff need to explain what, if any, services area available to students regarding alcohol and/or other drug problems. 
CASE 4 SUMMARY

Case Number 4 was identified through the original survey as being successful in its ability to identify students harmfully involved with alcohol and/or other drugs and refer these students to appropriate services. Case Number 4 is a suburban high school with approximately 900 students in grades $9-12$.

Question 1. What kinds of formal drug education instruction programs exist in the school at each grade level?

Answer 1. All students receive drug education instruction through a required loth grade health class and the entire school receives drug education information through a variety of assemblies and student body presentations throughout the school year.

Question 2. What kind of formal program does the school have for identifying students who are harmfully involved with alcohol and/or other drugs?

Answer 2. The school has a formal student assistance program that is primarily responsible for identifying students who are harmfully involved with alcohol and/or other drugs. Staff members of the student assistance team, as well as several other teachers and support staff have received "impact training" and other inservice regarding drug education issues. Counselors and the building vice principals are very involved with this process. 
Question 3. Which school staff members participate in the identification of students who are harmfully involved with alcohol and/or other drugs?

Answer 3. All school staff inclusing teachers and support staff participate in the initial identification of students who are harmfully involved with alcohol and/or other drugs. Building administrators, counselors and student assistance team members proactively research student behaviors in an effort to identify those who may be harmfully involved with alcohol and/or other drugs.

Question 4. What kind of formal training do staff members receive to help them identify students who are harmfully involved with alcohol and/or other drugs?

Answer 4. A Core team of staff (student assistance team) has received extensive training in identifying and assisting student who are harmfully involved with alcohol and/or other drugs. Staff members have received "impact training" and other inservice from various private providers. Building counselors, building administrators and several teachers and support staff have also accessed various sessions of these inservice trainings.

Question 5. Which school staff members are involved in referring students who are harmfully involved with alcohol and/or other drugs to an appropriate service?

Answer 5. School counselors are primarily responsible for referring students who have been identified though the 
student assistance process. Building administrators work with counselors in referring students who have been identified through the school's disciplinary process.

Question 6. What kind of formal training do staff members receive to help them refer students who are harmfully involved with alcohol and/or other drugs to appropriate services?

Answer 6. Building counselors, building administrators and selected staff have received formal training in referral strategies. Also, the school contracts with a private provider for the services for a drug education specialist. This drug education specialist is highly trained and experienced in referring students to appropriate services when they have been identified as being harmfully involved with alcohol and/or other drugs.

Question 7. Does the school have a student peer assistance program related to substance abuse among students?

Answer 7. Yes, the school has an established student peer assistance program that they have developed themselves. The program is called "Dry Wave," and students receive inservice related to drug education issues and are actively involved in sponsoring student activities that are "drug free."

Question 8. Does the school have an established process for helping students obtain formal assessment 
relative to alcohol and/or other drug abuse and chemical dependency?

Answer 8. The school contracts with a private provider such that students can obtain a formal assessment relative to alcohol and/or other drug abuse and chemical dependency at no cost. students identified as possibly being harmfully involved with alcohol and/or other drugs through the school's disciplinary process are required to take a formal assessment in order to avoid longterm suspension.

Question 9. Does the school have an established reentry program for students returning after having received counseling or treatment for alcohol and/or other drug abuse?

Answer 9. Yes, the school operates a daily reentry class for students returning school after having received counseling or treatment for alcohol and/or other drug abuse. The class is operated on a daily basis and is at the very beginning of a day. Students can remain in the class for as many semesters as they choose. Regular high school credit is given for participation in this class.

Question 10. During the 1987-88 school year, did the school have a formal written policy regarding student alcohol and/or other drug abuse, and are students aware of it?

Answer 10. Yes, the school had a formal written policy during the 1987-88 school year, and this policy was 
widely distributed to parents and students alike. Distribution strategies include the student handbook, student orientations and parent letters.

Question 11. How does the school's drug education intervention program utilize outside agencies and organizations?

Answer 11. The school contracts with a private counseling service for formal assessment services and other drug education inservice services. No community organizations participate in the school's drug education intervention program.

Question 12. What are the most important aspects of your school's drug education intervention program?

Answer 12. Staff and administrators all feel that the contracted assessment program is critical to the success of their drug education intervention program. Also, a caring attitude among staff and administration for students with these problems is of particular importance. Longterm success for students is greatly increased by having the recovery class. Consistency and the school's administrative approach to this program is very important. The existing level of staff understanding, via inservice, is also critical.

Question 13. How does central office administration and building administration support the school's drug education intervention program? 
Answer 13. School staff indicates that there is a very high level of support from some central office administration and building administration for the school's drug education intervention program. This support is seen through the financial resources that are made available to the school, such as funds for the assessment program and teacher inservice. Support is also seen through the actions of administrators in that they reinforce staff for their efforts in this area.

Question 14. How does the community support the school's drug education intervention program?

Answer 14. There is no significant community support for this school's drug education intervention program as described by staff and administration.

Question 15. How is the school's drug education intervention program managed (administered)?

Answer 15. The school's drug education intervention program is primarily managed by the school counselors and a vice principal, although much of the case management is also conducted by the teacher in charge of the recovery class and the drug education specialist that is contracted for formal assessments and other services.

Question 16. How can the school's drug education intervention program be improved?

Answer 16. Staff and administration alike agree that there needs to be increased and ongoing training of staff on 
various drug education issues. Administration and staff feel that there needs to be continuous efforts to increase the sensitivity of staff toward students who are suffering these problems. Counselors and administrators would like to see support groups made available on campus for students experiencing these problems. Administration is especially concerned that addition money is necessary to support drug education intervention programs because the schools are currently using basic education monies that are already in short supply. students indicated an interest in more information through classes regarding substance abuse issues. Students who were participating in the recovery class indicated that there is a need for support services and counseling during those times of the year when school is not in session.

\section{CASE 5 SUMMARY}

Case Number 5 was identified through the original survey as being successful in its ability to identify students harmfully involved with alcohol and/or other drugs and refer these students to appropriate services. Case Number 5 is a rural high school with approximately 600 students in grades 9-12.

Question 1. That kinds of formal drug education instruction programs exist in the school at each grade level? 
Answer 1. Students receive formal drug education instruction in several classes. The required high school health class contains several units that specifically address alcohol and drug education. Other high school classes have also incorporated drug education units. These classes include contemporary problems, home and family and physical education. The school also coordinates a series of student body presentations each school year that includes various speakers that address the issues of alcohol and drug abuse among students.

Question 2. What kind of formal program does the school have for identifying students who are harmfully involved with alcohol and/or other drugs?

Answer 2. The school operates a trained core team with a building coordinator who has release time to manage this program. All building staff are trained in identifying students who are harmfully involved with alcohol and/or other drugs and referring them to administration. Core team members receive additional training on how to investigate student behavior and performance in order to assess whether or not a student is harmfully involved with alcohol and/or other drugs.

Question 3. Which school staff members participate in the identification of students who are harmfully involved with alcohol and/or other drugs?

Answer 3. All staff members participate in the 
identification of students who are harmfully involved with alcohol and/or other drugs, although core team members continue to work on suspected student cases after a student has been initially identified as someone who is possibly involved with alcohol and/or other drugs.

Question 4. What kind of formal training do staff members receive to help them identify students who are harmfully involved with alcohol and/or other drugs?

Answer 4. All staff members have received training in initial identification strategies and related drug education issues. Core team members have received additional, more intensive training in regard to identification strategies.

Question 5. Which school staff members are involved in referring students who are harmfully involved with alcohol and/or other drugs to an appropriate service?

Answer 5. The core team works with school administration, counselors, the drug education coordinator and a contracted assessment specialist in referring students who are harmfully involved with alcohol and/or other drugs to an appropriate service.

Question 6. What kind of formal training do staff members receive to help them refer students who are harmfully involved with alcohol and/or other drugs to appropriate services?

Answer 6. Core team members, building administrators, counselors, the drug education specialist and the assessment 
specialist have all received formal training in numerous student assistance program skills that help them refer students who are harmfully involved with alcohol and/or other drugs to appropriate services.

Question 7. Does the school have a student peer assistance program related to substance abuse among students?

Answer 7. The school does not operate a student peer assistance program related to substance abuse among students. Administrators and staff acknowledge that they have operated such a program in the past, but found it to be of little value.

Question 8. Does the school have an established process for helping students obtain formal assessment relative to alcohol and/or other drug abuse and chemical dependency?

Answer 8. Yes, the district contracts with a private provider to make formal assessment available to students at no cost. The private provider works closely with other school staff in referring students who are harmfully involved with alcohol and/or other drugs to appropriate services.

Question 9. Does the school have an established reentry program for students returning after having received counseling or treatment for alcohol and/or other drug abuse? Answer 9. The core team, counselors, the drug 
education specialist and the assessment specialist work with administration to assist students who are returning to school after having received counseling or treatment for alcohol and/or other drug abuse. Staff also works to coordinate and monitor student participation in outside support groups.

Question 10. During the 1987-88 school year, did the school have a formal written policy regarding student alcohol and/or other drug abuse, and are students aware of it?

Answer 10. Yes, the school did have a formal written policy regarding student alcohol and/or other drug abuse during the 1987-88 school year. This policy was printed in the student handbook and distributed to all students. Also, information regarding the policy is made available to students, parents and staff through numerous school publications and community orientations.

Question 11. How does the school's drug education intervention program utilize outside agencies and organizations?

Answer 11. The school's program works cooperatively with various local treatment agencies for staff training and student placement. Various government agencies and community organizations have also committed resources to support the school's drug education program.

Question 12. What are the most important aspects of 
your school's drug education intervention program?

Answer 12. Administration and staff agree that one of the most important aspects of the school's drug education intervention program was that there is a designated individual who manages this program and that person receives release time to conduct those responsibilities. Administration and staff also identify free assessment services as being critically important to their program's success. Extensive staff training was also identified as being very important.

Question 13. How does central office administration and building administration support the school's drug education intervention program?

Answer 13. Central office administration and building administration is recognized as being very supportive of the school's drug education intervention program. In addition to moral support, central office administration and building administration work hard to provide financial resources to operate the program. Administration is also very public about their commitment to and support of drug education programs in the school.

Question 14. How does the community support the school's drug education intervention program?

Answer 14. According to administration and staff, community support for the school's drug education intervention program is minimal. Staff observe that the school's 
problems are compounded by the fact that many parents are themselves abusing alcohol and/or other drugs, and they are contributing to their children's problems.

Question 15. How is the school's drug education intervention program managed (administered)?

Answer 15. The school's drug education intervention program is managed by a drug education specialist that is released from teaching responsibilities for three hours each day to conduct the program. The drug education specialist coordinates core team activities, works with counselors and administration and also works with the assessment specialist to ensure that students receive prompt assistance with their problems.

Question 16. How can the school's drug education intervention program be improved?

Answer 16. Administration and other staff agree that additional resources are needed to continue and improve their existing program. Money is needed for additional staff time to manage the program because the time that is presently allocated is insufficient. Administration and staff also acknowledge that additional staff training will be an ongoing need for maintaining and improving their drug education intervention program. To improve the program, community support wust be improved and counseling services must be made available for the families of students who are harmfully involved with alcohol and/or other drugs. 
CASE 6 SUMMARY

Case Number 6 was identified through the original survey as being unsuccessful in its ability to identify students harmfully involved with alcohol and/or other drugs and refer these students to appropriate services. Case Number 6 is a rural high school with approximately 800 students in grades $9-12$.

Question 1. What kinds of formal drug education instruction programs exist in the school at each grade level?

Answer 1. All students are required to take a health course that is typically offered during the 10th grade. This health class includes a unit on drug education. No other formal drug education programs exist in the school.

ouestion 2. What kind of formal program does the school have for identifying students who are harmfully involved with alcohol and/or other drugs?

Answer 2. There is no formal program for identifying students who are harmfully involved with alcohol and/or other drugs although administrators and counselors often identify students through disciplinary referrals.

Question 3. Which school staff members participate in the identification of students who are harmfully involved with alcohol and/or other drugs?

Answer 3. Building administrators and school counselors will primarily identify students who are 
harmfully involved with alcohol and/or other drugs because students are referred to them for disciplinary reasons or other trouble.

Question 4. What kind of formal training do staff members receive to help them identify students who are harmfully involved with alcohol and/or other drugs?

Answer 4. During the 1987-88 school year, there was no formal training program for staff related to helping them identify students who are harmfully involved with alcohol and/or other drugs.

Question 5. Which school staff members are involved in referring students who are harmfully involved with alcohol and/or other drugs to an appropriate service?

Answer 5. Building administrators and counselors would be responsible for referring students to appropriate services.

question 6. What kind of formal training do staff members receive to help them refer students who are harmfully involved with alcohol and/or other drugs to appropriate services?

Answer 6. During the 1987-88 school year, no formal training program existed for staff members to help students who are harmfully involved with alcohol and/or other drugs to appropriate services.

Question 7. Does the school have a student peer assistance program related to substance abuse among 
students?

Answer 7. The school operates two student peer assistance programs related to substance abuse: Washington Teen Institute and Natural Helpers.

Question 8. Does the school have an established process for helping students obtain formal assessment relative to alcohol and/or other drug abuse and chemical dependency?

Answer 8. The school has no established process for helping students obtain formal assessment relative to alcohol and/or other drug abuse and chemical dependency.

Question 9. Does the school have an established reentry program for students returning after having received counseling or treatment for alcohol and/or other drug abuse?

Answer 9. The school has no established reentry program for students returning after having received counseling or treatment for alcohol and/or other drug abuse. Question 10. During the 1987-88 school year, did the school have a formal written policy regarding student alcohol and/or other drug abuse, and are students aware of it?

Answer 10. Yes, during the 1987-88 school year, the school did have a formal written policy regarding student alcohol and/or other drug abuse. This policy was widely distributed through a student handbook and other school publications. 
Question 11. How does the school's drug education intervention program utilize outside agencies and organizations?

Answer 11. No outside agencies and organization participated in the school's drug education intervention program.

Question 12. What are the most important aspects of your school's drug education intervention program?

Answer 12. Administration and staff both identify the need for major changes in the school's drug education intervention program.

Question 13. How does central office administration and building administration support the school's drug education intervention program?

Answer 13. During the 1987-88 school year, staff felt that central office administration and building administration both began recognize the need for additional drug education services in the school. Efforts were initiated to develop various programs for the 1988-89 school year.

Question 14. How does the community support the school's drug education intervention program?

Answer 14. Administration and staff agree that there was no significant community support for the school's drug education intervention program.

Question 15. How is the school's drug education intervention program managed (administered)? 
Answer 15. During the 1987-88 school year, there was no established management structure for the school's drug education intervention program.

Question 16. How can the school's drug education intervention program be improved?

Answer 16. Administration and other staff agree that a person was needed to coordinate drug education activities and offer direct student services. Administration and staff also recognize the need for staff training throughout the building relative to drug education issues. Staff identified the need to get parents and other community members involved with the school's efforts. Administration and staff alike indicate that financial resources and staff time will need to be made available if an effective program is to be developed. They also recognize that the school needs to be able to access someone with expertise in this area and have that person actually work to identify students who are harmfully involved with alcohol and/or other drugs and assist these students. staff feels that they already have too much to do.

\section{CASE 7 SUMMARY}

Case Number 7 was identified through the original survey as being successful in its ability to identify students harmfully involved with alcohol and/or other drugs and refer these students to appropriate services. Case 
Number 7 is an urban high school with approximately 1,300 students in grades 9-12.

question 1. What kinds of formal drug education instruction programs exist in the school at each grade level?

Answer 1. The school has a formal drug education program at the tenth grade level. They also have a special family life section which is aimed at students who come from alcoholic families.

Question 2. What kind of formal program does the school have for identifying students who are harmfully involved with alcohol and/or other drugs?

Answer 2. The school has a formal student assistance program with a core team concept. They also have a fulltime staff person who coordinates the core team activities, handles referrals from the staff and makes assessment of students. The vice principal of the school receives referrals for all students suspected of being harmfully involved with alcohol and/or other drugs and turns those referrals over to the drug education specialist when appropriate.

Question 3. Which school staff members participate in the identification of students who are harmfully involved with alcohol and/or other drugs?

Answer 3. All staff members participate in the identification of students. 
Question 4. What kind of formal training do staff members receive to help them identify students who are harmfully involved with alcohol and/or other drugs?

Answer 4. All staff have been trained in an extensive two day chemical dependency workshop. This workshop emphasizes chemical dependency as a disease and helps faculty members to recognize symptoms and signs.

Question 5. Which school staff members are involved in referring students who are harmfully involved with alcohol and/or other drugs to an appropriate service?

Answer 5. School administrators, counselors and the drug specialist screen referrals. The drug specialist does the final determination on which referral is appropriate for treatment.

Question 6. What kind of formal training do staff members receive to help them refer students who are harmfully involved with alcohol and/or other drugs to appropriate services?

Answer 6. Administrators, counselors, drug education specialists and core team members have all received training that will help them refer students who are harmfully involved with alcohol and/or other drugs to appropriate services.

Question 7. Does the school have a student peer assistance program related to substance abuse among students? 
Answer 7. The school has a Natural Helpers program, Washington Teen Institute and a Red cross program for students against drinking and driving.

Question 8. Does the school have an established process for helping students obtain formal assessment relative to alcohol and/or other drug abuse and chemical dependency?

Answer 8. Yes, the school has a fulltime drug intervention specialist who has a drug certification in the state of Washington and is also to provide formal assessments.

Question 9. Does the school have an established reentry program for students returning after having received counseling or treatment for alcohol and/or other drug abuse?

Answer 9. Yes, the school has a daily class for students returning from drug treatment programs.

Question 10. During the 1987-88 school year, did the school have a formal written policy regarding student alcohol and/or other drug abuse, and are students aware of it?

Answer 10. Yes, there is a policy existing on alcohol and/or other drug abuse. Students are notified of this policy is in their handbook and are given some orientation to the policy during sophomore orientation period. students are more aware of the activity code than they are the discipline policy in this school. 
Question 11. How does the school's drug education intervention program utilize outside agencies and organizations?

Answer 11. The school uses drug treatmert programs local in the community. close coordination is made for a smooth reentry in the process. Out patient drug treatment programs and school counselors work together to coordinate treatment needs versus school needs.

Question 12. What are the most important aspects of your school's drug education intervention program?

Answer 12. Teachers and administrators all agree that the most important aspects of their school's drug education intervention program was their fulltime drug education intervention specialist. Another critical aspect is the recovery class. School administrators and counselors felt that the training for faculty was also important.

Question 13. How does central office administration and building administration support the school's drug education intervention program?

Answer 13. At this school, there was widespread agreement that the central office administration was highly supportive of the drug education program. Building administrators and central office administrators have participated in school district training for the drug education intervention program.

Question 14. How does the community support the 
school's drug education intervention program?

Answer 14. According to administration and staff the community support for the school's drug education intervention program is growing. There have been widespread newspaper accounts of the program plus an all out attempt of community awareness training. The school district has received one large community grant to work with children from alcoholic families.

Question 15. How is the school's drug education intervention program managed (administered)?

Answer 15. Central office special services program director manages the overall drug education intervention program districtwide. Local school building vice principal supervises the drug education specialist in building and coordinates the buildingwide drug education effort.

Question 16. How can the school's drug education intervention program be improved?

Answer 16. Administrators in this school felt that they would like to see a stabilization of financing of the program. Both administrators and staff felt that there was a need for increased parent education and parent involvement. Counselors and some students felt that coordination between school and treatment centers needed to be improved. Both administrators and counselors felt that there could be an improved effort on the part of outside agencies and treatment centers in helping schools to transition students 
back into school.

CASE 8 SUMMARY

Case Number 8 was identified through the original survey as being successful in its ability to identify students harmfully involved with alcohol and/or other drugs and refer these students to appropriate services. Case Number 8 is a rural high school with approximately 1,100 students in grades 9-12.

Question 1. What kinds of formal drug education instruction programs exist in the school at each grade level?

Answer 1. The school has a formal drug education program at the eleventh grade level.

Question 2. What kind of formal program does the school have for identifying students who are harmfully involved with alcohol and/or other drugs?

Answer 2. The school, during the 1987-88 school year, formed a core team of teachers and administrators especially trained at identifying students and making decisions on the referral of those students harmfully involved with alcohol and/or other drugs. They hired on a fulltime basis a drug education intervention specialist who provides direct intervention with students and parents after review by the core team. All teachers are then trained at filling out forms which identify behaviors related to alcohol and/or other 
drug abuse.

Question 3. Which school staff members participate in the identification of students who are harmfully involved with alcohol and/or other drugs?

Answer 3. The school has extensive participation on the part of all staff including classified and certified staff. Referrals from those staff members are provided to the core team who reviews on a weekly basis those students who appear to be having difficulty. Finally, the drug education intervention specialist works on the specific intervention.

Question 4. What kind of formal training do staff members receive to help them identify students who are harmfully involved with alcohol and/or other drugs?

Answer 4. The core team of staff members have had impact training. The rest of the staff, both certified and classified, have received some limited training on how to fill out identification forms and referrals forms to aid in the intervention process.

Question 5. Which school staff members are involved in referring students who are harmfully involved with alcohol and/or other drugs to an appropriate service?

Answer 5. All staff refer students to the core team. Core team members generate information from other staff who know the referred students.

Question 6. What kind of formal training do staff 
members receive to help them refer students who are harmfully involved with alcohol and/or other drugs to appropriate services?

Answer 6. All staff are trained in use of referral forms and the access process to the core team. Question 7. Does the school have a student peer assistance program related to substance abuse among students?

Answer 7. Yes, the school has a Natural Helpers program.

Question 8. Does the school have an established process for helping students obtain formal assessment relative to alcohol and/or other drug abuse and chemical dependency?

Answer 8. Yes, the school seems to have a clear cut process of identifying students who are in trouble with alcohol and/or other drugs. The staff, students and the core team are all comfortable with this process of referral. The drug education intervention specialist works closely with local treatment centers and community alcoholism center to refer students for formalized assessment when appropriate.

Question 9. Does the school have an established reentry program for students returning after having received counseling or treatment for alcohol and/or other drug abuse? Answer 9. Yes, the school has established a weekly 
group to help students deal with problems related to reentry from drug treatment programs.

Question 10. During the 1987-88 school year, did the school have a formal written policy regarding student alcohol and/or other drug abuse, and are students aware of it? Answer 10. Yes, however, students seem to be more aware of the policies related to extracurricular/cocurricular activities than they are the general policy related to drug abuse.

Question 11. How does the school's drug education intervention program utilize outside agencies and organizations?

Answer 11. This program utilizes outside agencies related to drug treatment. They have made excellent use of local resources to make formal assessments on students regarding the severity of their problems.

Question 12. What are the most important aspects of your school's drug education intervention program?

Answer 12. The staff and students felt that the most important aspect of the school's program was the fulltime drug education intervention specialist. They also felt that the participation and involvement of the core team was making their program successful.

Question 13. How does central office administration and building administration support the school's drug education intervention program? 
Answer 13. It was felt that the central office and building administration was supportive of the effort through release time for training of staff and for purchasing time for the drug education intervention specialist.

Question 14. How does the community support the school's drug education intervention program?

Answer 14. Participants from the community went to the state Building and Vision Conference in Yakima, Washington this year. Although the community support efforts have been small to date, staff felt that there was growing awareness and interest on the part of both parents and other community members toward working with students in trouble with alcohol and/or other drugs.

Question 15. How is the school's drug education intervention program managed (administered)?

Answer 15. The assistant superintendent of instruction at the central office and the principal at the school both supervise the drug education intervention specialist.

Question 16. How can the school's drug education intervention program be improved?

Answer 16. The staff and administrators felt that there should be more training on the part of the rest of the staff. They tended to be critical of the efforts in regards to not being as comprehensive as neighboring school districts. They were feeling confident with the program they had established but wished to see the drug education 
intervention specialist fulltime at the high school. They also felt that there should be a daily reentry class for students harmfully involved with alcohol and/or other drugs.

\section{CASE 9 SUMMARY}

Case Number 9 was identified through the original survey as being unsuccessful in its ability to identify students harmfully involved with alcohol and/or other drugs and refer these students to appropriate services. Case Number 9 is a suburban high school with approximately 1,100 students in grades 9-12.

Question 1. What kinds of formal drug education instruction programs exist in the school at each grade level?

Answer 1. The school health class offers some drug education instruction. No other formal instruction program exists.

Question 2. What kind of formal program does the school have for identifying students who are harmfully involved with alcohol and/or other drugs?

Answer 2. During the 1987-88 school year, there was no formal program to identify students and/or refer them to treatment.

Question 3. Which school staff members participate in the identification of students who are harmfully involved with alcohol and/or other drugs? 
Answer 3. During the 1987-88 school year, there was an informal process of referring students to counselors in hopes that counselors would be able to help find a resource form them.

Question 4. What kind of formal training do staff members receive to help them identify students who are harmfully involved with alcohol and/or other drugs?

Answer 4. Core team training was provided in 1987-88 in an effort to develop a program for the 1988-89 school year.

Question 5. Which school staff members are involved in referring students who are harmfully involved with alcohol and/or other drugs to an appropriate service?

Answer 5. Counselors are primarily responsible for referring students to appropriate services.

Question 6. What kind of formal training do staff members receive to help them refer students who are harmfully involved with alcohol and/or other drugs to appropriate services?

Answer 6. In 1987-88 school year, there had been no formal training for staff to help identify and refer students to appropriate services.

Question 7. Does the school have a student peer assistance program related to substance abuse among students?

Answer 7. The school has no peer assistance program. 
Question 8. Does the school have an established process for helping students obtain formal assessment relative to alcohol and/or other drug abuse and chemical dependency?

Answer 8. During the 1987-88 school year, there was no formal established process for helping students obtain formal assessments.

Question 9. Does the school have an established reentry program for students returning after having received counseling or treatment for alcohol and/or other drug abuse?

Answer 9. No, during the 1987-88 school year there was no established reentry program.

Question 10. During the 1987-88 school year, did the school have a formal written policy regarding student alcohol and/or other drug abuse, and are students aware of it?

Answer 10. Yes, they had a formal disciplinary policy written regarding student alcohol and/or other drug abuse. The students, when asked, were more aware of the discipline policies related around athletics and activities then they were the general policy around drug abuse.

Question 11. How does the school's drug education intervention program utilize outside agencies and organizations?

Answer 11. The school district in 1987-88 school year used outside treatment programs as a referral source plus 
the local community alcoholism center operated by the county has been a source of referral for drug assessment.

Question 12. What are the most important aspects of your school's arug education intervention program?

Answer 12. The biannual drug awareness program has been the high point of the drug education intervention program. This program creates a greater degree of awareness of services available and problems that exist for other students.

Question 13. How does central office administration and building administration support the school's drug education intervention program?

Answer 13. It was felt that central office was not highly supportive or highly visible in their support of the drug education intervention program.

Question 14. How does the community support the school's drug education intervention program?

Answer 14. The staff and students felt that the community needed to support the drug education intervention program in a more effective way.

Question 15. How is the school's drug education intervention program managed (administered)?

Answer 15. During the 1987-88 school year there was no established management for the program.

question 16. How can the school's drug education intervention program be improved? 
Answer 16. It was a feeling of the staff and students that efforts to date need to be expanded. There needs to be a fulltime drug education specialist or intervention specialist. There needs to be a greater involvement and commitment on the part of central office administration. Both staff and students felt that parents needed a greater amount of information for identifying symptoms and signs.

CASE 10 SUMMARY

Case Number 10 was identified through the original survey as being successful in its ability to identify students harmfully involved with alcohol and/or other drugs and refer these students to appropriate services. Case Number 10 is a suburban high school with approximately 1,600 students in grades 9-12.

Question 1. What kinds of formal drug education instruction programs exist in the school at each grade level?

Answer 1. All students are required to take a health class that includes various units on alcohol and drug education. In addition, there is an elective drug education class that most students take during their high school tenure. In addition, each year there are several schoolwide assemblies and presentations that address alcohol and drug issues.

Question 2. What kind of formal program does the 
school have for identifying students who are harmfully involved with alcohol and/or other drugs?

Answer 2. The school operates a core team that meets regularly to review and discuss information regarding students who may be harmfully involved with alcohol and/or other drugs. The core team is chaired by a building administrator who coordinates the school's overall drug education activities and works to manage services for individual students tho were identified through the core team process. Administrators and counselors work together with the core team in this identification process.

Question 3. Which school staff members participate in the identification of students who are harmfully involved with alcohol and/or other drugs?

Answer 3. All school staff including support personnel participate in the identification of students who are harmfully involved with alcohol and/or other drugs, although the core team, school counselors, drug education teachers and the building administrators are primarily responsible for this activity.

Question 4. What kind of formal training do staff members receive to help them identify students who are harmfully involved with alcohol and/or other drugs?

Answer 4. All staff receive general awareness training, and most staff have received intensive core team training. In addition, the counselors, building administra- 
tors and drug education teachers have received intensive training in this area and some staff have completed training for alcohol and drug certification.

Question 5. Which school staff members are involved in referring students who are harmfully involved with alcohol and/or other drugs to an appropriate service?

Answer 5. School administration works with building counselors, drug education teachers, core team staff and assessment specialists in referring students who are harmfully involved with alcohol and/or other drugs to appropriate services.

question 6. What kind of formal training do staff members receive to help them refer students who are harmfully involved with alcohol and/or other drugs to appropriate services?

Answer 6. Most staff members including counselors, building administrators, drug education teachers, core team members and assessment specialists have all received intensive training to help them refer students who are harmfully involved with alcohol and/or other drugs to appropriate services.

Question 7. Does the school have a student peer assistance program related to substance abuse among students?

Answer 7. The school operates two student peer assistance programs related to substance abuse: Natural 
Helpers and students Understanding Drinking and Drugging. staff feels that both of these programs are very beneficial. Question 8. Does the school have an established process for helping students obtain formal assessment relative to alcohol and/or other drug abuse and chemical dependency?

Answer 8. Yes, the school has a formal process for helping students obtain formal assessment relative to alcohol and/or other drug abuse and chemical dependency. The school works with various treatment agencies and government agencies to provide these services to students at no cost.

Question 9. Does the school have an established reentry program for students returning after having received counseling or treatment for alcohol and/or other drug abuse?

Answer 9. Yes, the school operates an established reentry progran for students returning to school after having received counseling or treatment for alcohol and/or other drug abuse. The reentry program is a daily class that operates as a support group to the students as well as being a class where students receive assistance in keeping up with their studies. In addition to the daily reentry class, formal rap sessions are conducted by a therapist twice a week for students who want to discuss their alcohol and drug problems.

Question 10. During the 1987-88 school year, did the 
school have a formal written policy regarding student alcohol and/or other drug abuse, and are students aware of it?

Answer 10. Yes, during the 1987-88 school year, the school did have a formal written policy regarding student alcohol and/or other drug abuse. This policy was distributed through a student handbook and parent newsletter.

Question 11. How does the school's drug education intervention program utilize outside agencies and organizations?

Answer 11. The school utilizes various government agencies, as well as local private treatment centers for staff training and inservice, as well as student treatment services. These agencies provide money and/or staff who work with the school to provide training programs and assessment services available.

Question 12. What are the most important aspects of your school's drug education intervention program?

Answer 12. The most important aspects of the school's drug education intervention program include the onsite support groups, the core team that works to identify these students initially, the ability to provide students with free assessment services and the building-wide commitment of staff to this program.

Question 13. How does central office administration and building administration support the school's drug education intervention program? 
Answer 13. Central office administration and building administration have been very supportive in providing resources for staff training and curriculum materials. Building administration has also been very supportive in developing the reentry class and other support group activities. Building administrations public commitment and support to the concept of school based education efforts has been critical to staff commitment.

Question 14. How does the community support the school's drug education intervention program?

Answer 14. Administration and staff agree that community support for the school's drug education intervention program is area that can improve greatly. School staff feels that they can't do it all themselves, and they need community members to assist them.

question 15. How is the school's drug education intervention program managed (administered)?

Answer 15. The school's drug education intervention program is currently managed by a building administrator that does this work in addition his/her other responsibilities. The individual exhibits a very strong personal commitment to these issues, but recognizes that additional staff time is needed if the present level of management is to be continued.

Question 16. How can the school's drug education intervention program be improved? 
Answer 16. Administration and other staff agree that additional staff time must be made available for managing and coordinating the school's drug education intervention program. Staff identifies the need for additional drug education for all students at all grade levels. Administration and staff identify the need for additional community and parent involvement, and the need for widespread public education regarding alcohol and drug issues in our schools. Administration stated that free assessment services for students is a must. They also recognize that more staff time and staff training will be needed if we are every adequately address the problems related to student abuse of alcohol and/or other drugs.

\section{CASE 11 SUMMARY}

Case Number 11 was identified through the original survey as being successful in its ability to identify students harmfully involved with alcohol and/or other drugs and refer these students to appropriate services. Case Number 11 is a suburban high school with approximately 1,600 students in grades 10-12.

Question 1. What kinds of formal drug education instruction programs exist in the school at each grade level?

Answer 1. All students receive at least two weeks of formal instruction during the required health class that 
must be taken prior to graduation. In addition, the Home and Family course taken by most students includes a unit on substance abuse issues. During the year some information is presented through all school assemblies and various school communications.

Question 2. What kind of formal program does the school have for identifying students who are harmfully involved with alcohol and/or other drugs?

Answer 2. The school has a trained core team of teachers, administrators, counselors and support staff who meet regularly and work with the entire school staff in identifying students who are harmfully involved with alcohol and/or other drugs.

Question 3. Which school staff members participate in the identification of students who are harmfully involved with alcohol and/or other drugs?

Answer 3. All staff including teachers, administrators, counselors and support staff have been trained in awareness information and skills on how to identify students who are harmfully involved with alcohol and/or other drugs. All building staff participate in the identification process.

Question 4. What kind of formal training do staff members receive to help them identify students who are harmfully involved with alcohol and/or other drugs?

Answer 4. All staff have been trained in general and 
identification skills. Most of the staff has also received two or three days of intensive training in a program called Impact. This program deals with training staff to identify and assist students who are harmfully involved with alcohol and/or other drugs.

Question 5. Which school staff members are involved in referring students who are harmfully involved with alcohol and/or other drugs to an appropriate service?

Answer 5. An assistant principal, the school counselors and other members of the core team work together in referring students who are harmfully involved with alcohol and/or other drugs. The core team meets each week, and more often if needed, to consider services that various students may require.

Question 6. What kind of formal training do staff members receive to help them refer students who are harmfully involved with alcohol and/or other drugs to appropriate services?

Answer 6. All members of the core team have received Impact training which includes skills for identifying resources that students may need when they are harmfully involved with alcohol and/or other drugs and also skills on how to refer students and their families to these resources. Question 7. Does the school have a student peer assistance program related to substance abuse among students? 
Answer 7. Yes, the school operates a Natural Helpers program that trains students to informally identify students who may be harmfully involved with alcohol and/or other drugs and encourage these students to seek assistance.

Question 8. Does the school have an established process for helping students obtain formal assessment relative to alcohol and/or other drug abuse and chemical dependency?

Answer 8. Yes, the school contracts with a private agency for formal assessment services. These formal assessment services are made available to all students at no cost.

Question 9. Does the school have an established reentry program for students returning after having received counseling or treatment for alcohol and/or other drug abuse?

Answer 9. Yes, the school operates a daily recovery class for students. Students in the recovery class may include students who have received treatment for chemical dependency and are now returning to school or students who have been assessed to have serious problems related to substance abuse.

Question 10. During the 1987-88 school year, did the school have a formal written policy regarding student alcohol and/or other drug abuse, and are students aware of it?

Answer 10. Yes, the school has an established formal written policy regarding student alcohol and drug abuse and 
the policy is widely distributed through the student handbook and school publications that are mailed to all parents. The policy deals with disciplinary concerns as well as procedures for students seeking assistance that have not been disciplined.

Question 11. How does the school's drug education intervention program utilize outside agencies and organizations?

Answer 11. In addition to utilizing a local private counseling agency for assessment services, the school has arranged for the assessment services to be paid by the local Kiwanis organization.

Question 12. What are the most important aspects of your school's drug education intervention program?

Answer 12. Teachers, support staff, counselors and administration agree that staff training has been an especially important aspect of the school's drug education intervention program. In addition, the availability of assessment services and the recovery program are critical to the school's continued success.

Question 13. How does central office administration and building administration support the school's drug education intervention program?

Answer 13. Teachers, counselors and support staff all agree that building administration has been very supportive of the school's drug education intervention program. 
Although central office was also identified as being supportive, the central office was also criticized for not providing sufficient resources to adequately fund the existing program.

Question 14. How does the community support the school's drug education intervention program?

Answer 14. All staff interviewed felt that there was not enough communication with the community to determine whether or not there was support for the school's drug education intervention program. Given the absence of any staff perceptions of community support, this researcher feels that community support is minimal.

Question 15. How is the school's drug education intervention program managed (administered)?

Answer 15. The school's drug education intervention program is managed primarily by one of the school's assistant principals, although the school's security officer coordinates the meeting and activities of the core team.

Question 16. How can the school's drug education intervention program be improved?

Answer 16. All staff interviewed felt that there needed to be additional and ongoing training made available to staff in issues related to drug education. Staff also felt that more time had to be made available to members of the core team so that they didn't have to do their core team work over and above their other existing full time job 
responsibilities. All staff interviewed also felt that parents needed to become more informed about drug education issues and the school's drug education program. Everyone also indicated that additional resources were going to be needed if the program was going to be adequately maintained. Staff was especially concerned that funding for the assessment services might dry up and those services would become unavailable to students.

\section{CASE 12 SUMMARY}

Case Number 12 was identified through the original survey as being unsuccessful in its ability to identify students harmfully involved with alcohol and/or other drugs and refer these students to appropriate services. Case Number 12 is a suburban high school with approximatel $l_{Y} 1,600$ students in grades 9-12.

Question 1. What kinds of formal drug education instruction programs exist in the school at each grade level?

Answer 1. All students are required to take health education. Health education is a one semester class that is usually taken by students while they are in the 10th grade. In the health education class, there is a unit on the effects of drugs and the dangers of drug use. There is no other formal drug education instruction that takes place at other grade levels. 
Question 2. What kind of formal program does the school have for identifying students who are harmfully involved with alcohol and/or other drugs?

Answer 2. The school has no formal program for identifying students who are harmfully involved with alcohol and/or other drugs, but counselors and administrators often identify students who are harmfully involved with alcohol and/or other drugs because of disciplinary referrals or excessive absences.

Question 3. Which school staff members participate in the identification of students who are harmfully involved with alcohol and/or other drugs?

Answer 3. School counselors and building administrators are the staff members who would most usually participate in the identification of students who are harmfully involved with alcohol and/or other drugs.

Question 4. What kind of formal training do staff members receive to help them identify students who are harmfully involved with alcohol and/or other arugs?

Answer 4. Staff members receive no formal training in how to identify students who are harmfully involved with alcohol and/or other drugs.

Question 5. Which school staff members are involved in referring students who are harmfully involved with alcohol and/or other drugs to an appropriate service?

Answer 5. School administrators and counselors would 
be the individuals responsible for referring students who are harmfully involved with alcohol and/or other drugs to appropriate services. Administrators would tend to deal with students who are being referred for disciplinary reasons, while counselors would tend to deal with students who are being referred to services for other reasons.

Question 6. What kind of formal training do staff members receive to help them refer students who are harmfully involved with alcohol and/or other drugs to appropriate services?

Answer 6. Staff receive no formal training that would help them refer students who are harmfully involved with alcohol and/or other drugs to appropriate services.

Question 7. Does the school have a student peer assistance program related to substance abuse among students?

Answer 7. The school operated a Natural Helpers program during the 1987-88 school year, but it was not very active and it was abandoned because administration and staff didn't feel that it was worthwhile.

Question 8. Does the school have an established process for helping students obtain formal assessment relative to alcohol and/or other drug abuse and chemical dependency?

Answer 8. During the 1987-88 school year, the school had no established process for helping students obtain a 
formal assessment relative to alcohol and/or other drug abuse and chemical dependency.

question 9. Does the school have an established reentry program for students returning after having received counseling or treatment for alcohol and/or other drug abuse?

Answer 9. During the 1987-88 school year, the school did not have an established reentry program for students returning after having received counseling or treatment for alcohol and/or other drug abuse.

Question 10. During the 1987-88 school year, did the school have a formal written policy regarding student alcohol and/or other drug abuse, and are students aware of it?

Answer 10. Yes, the school did have a formal written policy regarding student alcohol and/or other drug abuse, and staff and students are made aware of this policy through a handbook and other written publications.

Question 11. How does the school's drug education intervention program utilize outside agencies and organizations?

Answer 11. No outside agencies and organizations participate in the school's drug education intervention program.

Question 12. What are the most important aspects of your school's drug education intervention program?

Answer 12. Administration and staff identify the need 
to improve and expand drug education intervention services as they most important aspect of the school's drug education intervention program.

Question 13. How does central office administration and building administration support the school's drug education intervention program?

Answer 13. When describing central office administration and building administration support, staff acknowledge that central office administration has supported the development of policies and procedures relative to drug education programs, but administration has provided little leadership and financial resources for drug education intervention efforts.

Question 14. How does the community support the school's drug education intervention program?

Answer 14. According to administration and other staff, there is no community support for the school's drug education intervention program. Administration and other staff observe that community members were willing to criticize schools in general for not addressing student drug abuse problems, but the community was not willing to work with the schools to improve student programs in this area.

Question 15. How is the school's drug education intervention program managed (administered)?

Answer 15. The school's drug education intervention program has no clear management structure. 
Question 16. How can the school's drug education intervention program be improved?

Answer 16. Administration and staff all agree that major changes are necessary in order to improve the school's drug education intervention program. Administration and staff both identify the need for additional resources that can be used for staff training and curriculum materials. Administration and staff also identify the need for services from a drug education specialist who "knows what they are doing." Additional drug education curriculum offerings at all grade levels were identified as a priority. Administrators and staff also identified the need for formal assessment services being made available and the need for an ongoing recovery program for returning students. 